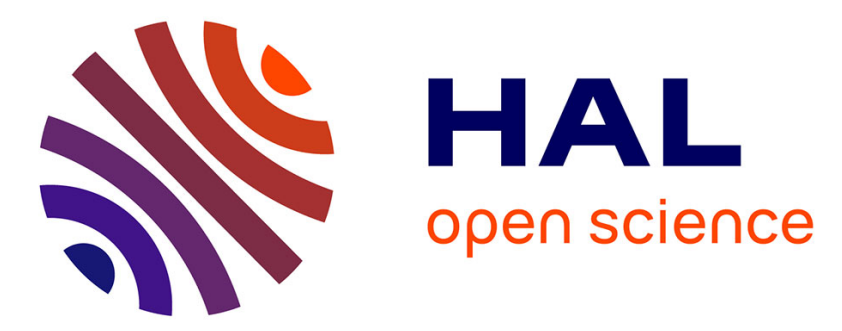

\title{
Experimental constraints on the formation of pegmatite-forming melts by anatexis of amphibolite: A case study from Evje-Iveland, Norway
}

Austin Gion, Philip Piccoli, Yingwei Fei, Philip Candela, Richard Ash

\section{To cite this version:}

Austin Gion, Philip Piccoli, Yingwei Fei, Philip Candela, Richard Ash. Experimental constraints on the formation of pegmatite-forming melts by anatexis of amphibolite: A case study from Evje-Iveland, Norway. Lithos, 2021, 398-399, pp.106342. 10.1016/j.lithos.2021.106342 . insu-03423319

HAL Id: insu-03423319

https://hal-insu.archives-ouvertes.fr/insu-03423319

Submitted on 10 Jan 2022

HAL is a multi-disciplinary open access archive for the deposit and dissemination of scientific research documents, whether they are published or not. The documents may come from teaching and research institutions in France or abroad, or from public or private research centers.
L'archive ouverte pluridisciplinaire HAL, est destinée au dépôt et à la diffusion de documents scientifiques de niveau recherche, publiés ou non, émanant des établissements d'enseignement et de recherche français ou étrangers, des laboratoires publics ou privés.

\section{(ㄷ)(1) $\$$}

Distributed under a Creative Commons Attribution - NonCommerciall 4.0 International 


\title{
Experimental constraints on the formation of pegmatite-forming melts by anatexis of amphibolite: A case study from Evje-Iveland, Norway
}

\author{
Austin M. Gion ${ }^{\mathrm{a}, \mathrm{b}, *}$, Philip M. Piccoli ${ }^{\mathrm{a}}$, Yingwei Fei ${ }^{\mathrm{b}}$, Philip A. Candela ${ }^{\mathrm{a}}$, Richard D. Ash ${ }^{\mathrm{a}}$ \\ ${ }^{a}$ Department of Geology, University of Maryland, College Park, MD, USA \\ ${ }^{\mathrm{b}}$ Earth and Planets Laboratory, Carnegie Institution for Science, 5251 Broad Branch Road N.W., Washington, DC 20015, USA
}

\section{A R T I C LE I N F O}

\section{Keywords}

Pegmatite

Amphibolite

Evje-Iveland

Anatexis

Norway

\begin{abstract}
A B S T R A C T
The Evje-Iveland pegmatite field in Norway contains pegmatites that are known for their rare scandium mineralization. The petrogenesis of these pegmatites has been debated in the literature for nearly a century. Hypotheses for the origin of the pegmatite-forming melt have included either anatexis of the host amphibolite in vapor-absent conditions, wherein scandium is scavenged from the host amphibolite; or magmatic differentiation, wherein scandium is concentrated through magmatic processes. In order to test the hypothesis that the pegmatite-forming melt was sourced from the host amphibolite, partial melting experiments on the host amphibolite have been performed. These experiments were performed at temperatures ranging from 700 to $1064{ }^{\circ} \mathrm{C}$ and pressures between 400 and $550 \mathrm{MPa}$ in a piston-cylinder apparatus. The solidus of the host amphibolite has been determined to be approximately $900{ }^{\circ} \mathrm{C}$ at $500 \mathrm{MPa}$ and is significantly higher than the temperature of pegmatite formation. Partial melting of $<40 \%$ can produce glasses that are broadly granitic in composition and are aluminum- and sodium-rich; however, they are less siliceous than the Evje-Iveland pegmatites. These glasses are also scandiumand REE-poor, and have REE patterns similar to leucosomes in vein-type migmatites, produced at low pressures, but dissimilar to the Evje-Iveland pegmatites. The results of these experiments are thus inconsistent with the hypothesis that the Evje-Iveland pegmatites or, by extension, other rare-element pegmatites, are the result of direct anatexis alone of common metamorphic rock such as amphibolites. It is proposed that the formation of the Evje-Iveland pegmatites is the result of partial melting of a scandium-rich ultramafic or mafic complex, differentiation of that partial melt, and emplacement of that melt into the host amphibolite. Thus, the pegmatite-forming melt may represent the final stages of magmatic differentiation, which is the preferred model for the formation of the Evje-Iveland pegmatites.
\end{abstract}

\section{Introduction}

Granitic pegmatites are coarse-grained, often small volume igneous rocks. Pegmatites are unique in igneous petrology in that they contain magmatic minerals that can be meters in size, gem quality minerals, high-purity feldspars and quartz, and rare-element mineralization. Pegmatites are also internally zoned, typically having a border zone, a wall zone, an intermediate zone, and a core, wherein the crystal size increases inward and growth is unidirectional.(Černý, 1991a; London, 2008, 2018). There are wide variety of pegmatite classes and subclasses of granitic pegmatites (summarized in Černý and Ercit (2005)) with rare-element pegmatites, which are known for their economic potential and enrichment in elements such as the REEs (rare-earth elements), $\mathrm{Li}, \mathrm{Be}, \mathrm{F}, \mathrm{Rb}, \mathrm{Cs}, \mathrm{Nb}$, Ta, etc., being one of the most well studied classes. Within the rare-element pegmatite classes there are two genetic families: 1) Niobium-Yttrium-Fluorine (NYF) and 2) Lithium-Cesium-Tantalum (LCT). NYF are generally associated with A-type granites and alkaline magmatism with enrichment of heavy rare earth elements, Be, Ti, Sc, and $\mathrm{Zr}$ in addition to $\mathrm{Nb}, \mathrm{Y}$, and $\mathrm{F}$ (Černý, 1991a; Černý and Ercit, 2005; London, 2005, 2008). LCT pegmatites are generally associated with S-type granites and are peraluminous with enrichment of Be, B, P, Rb, Sn among other elements in addition to Li, Cs, and Ta (London, 2008).

The petrogenesis of pegmatites is most commonly attributed to magmatic differentiation, where a parental granitic melt evolves through processes such as fractional crystallization that causes enrichment in trace elements and volatiles such as water and fluorine and ultimate emplacement and crystallization (Černý, 1991b; London,

\footnotetext{
* Corresponding author at: Univ. Orléans, CNRS, BRGM, ISTO, UMR 7327, F-45071 Orléans, France.

E-mail address: austin.gion@cnrs-orleans.fr (A.M. Gion)
} 
1992, 2005, 2008). Although magmatic differentiation associated with plutonism is the most commonly accepted petrogenesis, recently anatectic origins have been suggested, wherein the pegmatite-forming melt is the direct partial melt of metamorphic rocks such as metapelites and amphibolites (Konzett et al., 2018; Müller et al., 2017b; Simmons et al., 2016; Webber et al., 2019). The anatectic origin for rare-element pegmatites has generally been suggested based on observations made on natural studies; however, there is currently little experimental evidence to support this hypothesis and there are a number of questions that need to be answered. Such questions involve the trace element budget and bulk composition of anatectic melts and if they are able to produce rare-element pegmatites. In order to evaluate the hypothesis for the anatecic origin of pegmatites, experiments were performed in order to constrain the petrogenesis of the Evje-Iveland pegmatite field of the Sveconorwegian pegmatite province in Norway. The hypotheses for the petrogenesis of the Evje-Iveland pegmatites have changed over time to include both classical magmatic differentiation and an anatectic origin and is thus an excellent candidate to evaluate such theories.

\section{Geologic background}

The Sveconorwegian pegmatite province in Norway and Sweden is one of the largest occurrences of pegmatites in the world and contains over 5000 rare-element pegmatites (Müller et al., 2017b). Pegmatites in this province have been mined since the 1860s for feldspars, quartz, white mica, scandium, and beryllium (Müller et al., 2017b). Pegmatite formation occurred during the Sveconorwegian (Grenvillian) Orogeny $(1.2$ to $0.9 \mathrm{Ga}$ ) and continued into a period of post-orogenic quiescence. It has been proposed that there are three groups of pegmatites within the province, which are the result of: 1.) high-pressure, high-temperature metamorphism during the orogeny; 2.) low-pressures, high-temperatures post-orogenic extension; and, 3.) post-orogenic granite magmatism (Müller et al., 2017b). The Sveconorwegian pegmatites are typically classified as abyssal (i.e. barren or unmineralized) or rare-element pegmatites that have NYF characteristics (Müller et al., 2017b).

The Evje-Iveland pegmatite field is located within the Sveconorwegian pegmatite province and specifically in the Setesdal pegmatite district of the tectonometamorphic Rogaland-Hardangervidda-Telemark Sector. The Evje-Iveland pegmatite field contains some $400\left(>1000 \mathrm{~m}^{3}\right)$ pegmatites (Müller et al., 2015) hosted in the Vånne banded gneiss (an amphibolite gneiss), the Iveland-Gautestad metagabbro, and the Flåt-Mykleås metadiorite, and is in close proximity to the Høvringsvatnet granite (see Müller et al., 2015; Pedersen et al., 2009). The mineralogy of the Evje-Iveland pegmatites includes potassium feldspar (including var. amazonite), plagioclase (including var. cleavelandite), quartz, biotite, and muscovite, as well as accessory minerals such as magnetite, garnet, columbite-group minerals, beryl, and monazite (Bjørlykke, 1935; Snook, 2014 and references therein; Müller et al., 2015; Müller et al., 2017a). The pegmatites exhibit internal zonation and have a granitic wall, a megacrystic intermediate zone, and a core of quartz and feldspar (Müller et al., 2018) and have a NYF geochemical signature (Černý, 1991a; Müller et al., 2015). Another notable characteristic of the Evje-Iveland pegmatite field is the occurrence of scandium-bearing minerals, in particular the mineral thortveitite $\left(\mathrm{Sc}_{2} \mathrm{Si}_{2} \mathrm{O}_{7}\right)$, which was first discovered by Schetelig (1911) in an Iveland pegmatite.

The emplacement conditions of the Evje-Iveland pegmatites have previously been estimated from the pressures and temperatures of the intrusion of the Rogaland anorthosite-mangerite-charnockite complex in the southwestern Telemark Domain, $100 \mathrm{~km}$ west of the Evje-Iveland pegmatite field (Müller et al., 2015). The Rogaland complex is approximately coeval with emplacement of the pegmatites (Schärer et al., 1996; Vander Auwera et al., 2011). The complex is surrounded by a metamorphic aureole, with peak temperature estimates ranging from $\sim 1000{ }^{\circ} \mathrm{C}$ at the contact of the intrusion to $\sim 750{ }^{\circ} \mathrm{C}$ near the edges of the aureole $(\sim 15 \mathrm{~km}$ away from the contact) at a pressure of $\sim 500$ MPa (Drüppel et al., 2012; Jansen et al., 1985; Möller et al., 2002; Möller et al., 2003; Westphal et al., 2003). Emplacement of the intrusion was followed by a cooling stage, wherein the temperature was $\sim 610^{\circ} \mathrm{C}$ at $918 \pm 2 \mathrm{Ma}$ (Bingen and van Breemen, 1998). Thus, emplacement condition of Evje-Iveland pegmatites have been estimated to be between 550 and $600{ }^{\circ} \mathrm{C}$ at a pressure of 400 to $500 \mathrm{MPa}$ (Müller et al., 2015). Further, temperature has been estimated by titanium-in-quartz thermometry and is consistent with an emplacement temperature of approximately $613^{\circ} \pm 70^{\circ} \mathrm{C}$ Müller et al. (2015).

\subsection{Previous petrogenic hypotheses}

The original hypothesis for the petrogenesis of the Evje-Iveland pegmatites is that the magma that crystallized to form the Høvringsvatnet granite is the parental magma for the pegmatites and the pegmatites formed during the final stages of crystallization (e.g. Bjørlykke, 1937; Larsen et al., 2000). This interpretation was adopted due in part because of the close spatial association between the granite and the pegmatites (see Müller et al., 2015). Subsequently, it was found that the oxygen isotopes of mineral separates from the pegmatites range from $\delta^{18} \mathrm{O}_{\text {SMOW }} 0$ to $\sim+11 \%$ and the hydrogen isotopes for biotite and muscovite from the pegmatites range from $\delta \mathrm{D}_{\mathrm{SMO}}-37$ to $-93 \%$, which is consistent with the isotopic signature of the Høvringsvatnet granite (Taylor and Friedrichsen, 1983a, 1983b).

The ages of the rocks present a more complex story. $\mathrm{U}-\mathrm{Pb}$ dating of zircon from the Høvringsvatnet granite is consistent with a crystallization age of $981 \pm 6 \mathrm{Ma}$ (Snook, 2014), whereas the pegmatites have an age of $900.7 \pm 1.8$ from $\mathrm{U}-\mathrm{Pb}$ dating of columbite (Müller et al., 2017b); $906 \pm 6 \mathrm{Ma}$ (Seydoux-Guillaume et al., 2012) and $904.2 \pm 0.3 \mathrm{Ma}$ (Ling et al., 2017) from $\mathrm{U}-\mathrm{Pb}$ dating of monazite; and $910.2 \pm 14 \mathrm{Ma}$ from $\mathrm{Lu}-\mathrm{Hf}$ dating of gadolinite (Scherer et al., 2001). Thus, the age difference is at least $\sim 50$ million years. Due to this age difference, the hypothesis of pegmatite formation by fractionation from the Høvringsvatnet granite was rejected in favor of the hypothesis that pegmatite formation was a result of direct anatexis of the host amphibolite (Müller et al., 2015; Müller et al., 2017b; Romer and Smeds, 1996; Snook, 2014).

Müller et al. (2015) and Snook (2014) have suggested that the pegmatite-forming melt at Evje-Iveland resulted from the anatexis (15-30\% partial melting) of the host amphibolite. This partial melting occurred during the Sveconorwegian Orogeny (1145-900 Ma), wherein heat was provided to the system from crustal underplating (e.g. Andersen et al., 2002; Müller et al., 2017b; Vander Auwera et al., 2011). This petrogenetic model is supported by textural evidence (intermingled restite and leucosome material), the spatial association of the pegmatites to the amphibolites, and initial ${ }^{87} \mathrm{Sr} /{ }^{86} \mathrm{Sr}$ values of the pegmatites, which are generally consistent with a mantle-derived source (Müller et al., 2015; Müller et al., 2017b). Although the oxygen and hydrogen isotopes are similar between the pegmatites and host amphibolites, there are few data to support isotopic equilibrium or disequilibrium (Taylor and Friedrichsen, 1983a, 1983b).

\subsection{Unresolved questions}

If direct anatexis of the host rock was the petrogenetic mechanism that produced the pegmatites, several key questions need to be addressed: 1 ) What is the pressure and temperature required to partially melt the amphibolite?; 2) What is the bulk composition of that melt?; and 3) Does the melt have the trace element budget (e.g. scandium) required to generate rare-element mineralization (e.g. thortveitite) in the 
pegmatites? Scandium is of particular interest in this study and may act as a tracer during the pegmatite-forming process. Goldschmidt (1934) first hypothesized that the scandium enrichment in the pegmatites was the result of scavenging of scandium from the country rock (host amphibolite) by the pegmatite-forming melt. Bjørlykke (1935) agreed with Goldschmidt (1934) and stated that thortveitite $\left(\mathrm{Sc}_{2} \mathrm{Si}_{2} \mathrm{O}_{7}\right)$ formed as an early- to middle-stage mineral. Neumann (1961) disagreed with the Goldschmidt's hypothesis noting that the host amphibolite is not enriched in scandium and that minerals (including biotite, beryl, and columbite) from thortveitite-bearing pegmatites have higher scandium concentrations than the same minerals in thortveitite-absent pegmatites. Given that scandium is compatible in amphibole relative to a silicate melt, particularly at lower temperatures and higher $\mathrm{SiO}_{2}$ concentrations (Nandedkar et al., 2016), a pegmatite-forming melt in equilibrium with a residue containing amphibole is unlikely to be enriched in scandium. These issues are not exclusive to the Evje-Iveland pegmatite field or the Sveconorwegian pegmatite province. As noted above, the generation of pegmatite-forming melts by anatexis at granulite to amphibolite facies metamorphic conditions may generate abyssal (barren) pegmatites, but is not typically associated with rare-element pegmatites (Černý and Ercit, 2005). Thus, evaluating the role of anatexis in the formation of rare-element pegmatites is important to understanding the generation of pegmatites unrelated to plutonism.

\subsection{Experimental justification}

In an effort to test the hypothesis that the Evje-Iveland pegmatites formed as a result of direct anatexis of the amphibolite host rock, experiments were performed in order to determine the phase relations at pressures and temperatures corresponding to amphibolite and granulite metamorphic facies. The experiments reported here elucidate the pressure and temperature conditions where melting begins, as well as the major and trace element composition of that melt.

Partial melting experiments have been performed on a variety of amphibolite (or basaltic) compositions at amphibolite and granulite facies pressures and temperatures in vapor-absent systems (Beard and Lofgren, 1989, 1991; Rapp, 1995; Rapp et al., 1991; Rapp and Watson, 1995; Winther and Newton, 1991; Wolf and Wyllie, 1994; Wolf and Wyllie, 1995; Wyllie and Wolf, 1993). The results and interpretation of these previous studies can be summarized as follows. First, the vapor-absent solidus for a given amphibolite is strongly a function of bulk composition, and solidi have been estimated to be $<750{ }^{\circ} \mathrm{C}$ and up to $975{ }^{\circ} \mathrm{C}$ (Rapp et al., 1991; Wolf and Wyllie, 1994; Wyllie and Wolf, 1993). Second, the temperature of the solidus is a function of pressure. Wyllie and Wolf (1993) noted that at pressures where garnet is stable, the solidus abruptly "backbends" to significantly lower temperatures. Further, Petford and Gallagher (2001), utilizing available experimental data, determined an average global solidus temperature for amphibolites of $\sim 822{ }^{\circ} \mathrm{C}$ and that temperatures when partial melting occurs may exceed $900{ }^{\circ} \mathrm{C}$. Third, less than $\sim 40 \%$ partial melting can generate melts with tonalitic-trondhjemitic compositions that are depleted in heavy rare earth elements (HREEs) (e.g. Beard and Lofgren, 1991; Rapp et al., 1991; Wolf and Wyllie, 1995). Fourth, melting first occurs at the contact between plagioclase and amphibole and the amount of melt generated is controlled by the breakdown of amphibole, with the largest melt fractions occurring after complete consumption of amphibole (Rapp et al., 1991). Reactions that occur during melting involve the consumption of amphibole and plagioclase and the production of melt and minerals including more aluminous amphibole, more calcic or chemically similar plagioclase, clinopyroxene (diopsidic augite), magnesium-rich orthopyroxene, garnet, iron-titanium oxides, and olivine (Beard and Lofgren, 1991; Rapp, 1995; Rapp and Watson, 1995; Wolf and Wyllie,
1994). Finally, in natural settings, the generation of a melt in vapor-absent systems may be the result of underplating of the crust by a basaltic magma (Petford and Gallagher, 2001; Rapp and Watson, 1995).

There is significant variability in the solidus temperature and reaction products reported among experimental studies. It is clear that extrapolation of experimental studies to natural processes requires that the experiments be performed on material that is compositionally similar to the natural study site. Extrapolation of experimental studies to natural systems with dissimilar compositions is likely to lead to results that are not pertinent to the site and potentially misleading information. In the case of the Evje-Iveland pegmatite field, it is not known what the composition of the unmetamorphosed amphibolite was, although it was likely gabbroic. However, the amphibolite is the best representation of this composition. In order to elucidate the role of direct anatexis on the formation of the Evje-Iveland pegmatites partial melting experiments by using the host amphibolite as starting material have been performed. This amphibolite represents the potential source of the pegmatite-forming melt (Müller et al., 2015).

\section{Experimental methods}

The starting material for all experiments in this study was from a massive amphibolite provided courtesy of Axel Müller, Natural History Museum, Oslo, Norway. The sample locality (sample 23051707b; Rosing-Schow et al., 2018) is $80 \mathrm{~m}$ from the contact of the Steli pegmatite in the Evje-Iveland pegmatite field. The amphibolite is predominantly amphibole and plagioclase with minor apatite and iron-titanium oxides. The whole rock composition is given in Rosing-Schow et al. (2018), as well as presented in the supplementary files.

The amphibolite used as starting material was used in three different forms: a core, a powder, and a powder that was sieved to produce a uniformly smaller grain size. Cores of the amphibolite were acquired using 1 or $2 \mathrm{~mm}$ coring drill bit. The amphibolite sample was powdered in an alumina grinding dish within a shatterbox and an aliquot was sieved. The majority of the grains of the unsieved portion were $<200 \mu \mathrm{m}$ with a small portion between 200 and $400 \mu \mathrm{m}$ and the grains of the sieved portion were $<53 \mu \mathrm{m}$.

All experiments were conducted in a Boyd-England style end-loaded, piston-cylinder apparatus (Boyd and England, 1960), in $1 / 2$ or $3 / 4$ inch talc-Pyrex assemblies. The starting material was loaded into either $3 \mathrm{~mm}$ outer diameter $(0.126 \mathrm{~mm}$ wall thickness) gold capsules or $2 \mathrm{~mm}$ outer diameter $(0.126 \mathrm{~mm}$ wall thickness) platinum capsules that were 4-6 $\mathrm{mm}$ in length and sealed by welding. Capsules were placed in an outer $\mathrm{MgO}$ sleeve and packed with $\mathrm{MgO}$ powder, both of which were fired at $1000^{\circ} \mathrm{C}$. The $\mathrm{MgO}$ sleeves, along with fired $\mathrm{MgO}$ plugs, were then placed in a graphite, a Pyrex, and a talc sleeve, and finally wrapped in thin lead foil. In each experiment either two or four capsules were included, wherein the starting material in each capsule was either a core, unsieved powder, or sieved powder (Fig. 1; Table 1). In experiments containing sieved and unsieved powder, the sieved powder was placed inside of a platinum capsule to allow for easy identification after completion of the experiment. Core and unsieved powder experiments were contained in gold capsules.

Experiments were conducted at temperatures ranging from 700 to $1064{ }^{\circ} \mathrm{C}$ and pressures between 400 and $550 \mathrm{MPa}$ (Table 1) at the intrinsic oxygen fugacity of the piston-cylinder apparatus. Temperature was measured using type-C (95\%W5\%Re $-74 \% \mathrm{~W} 26 \% \mathrm{Re})$ thermocouples. The pressure reported in Table 1 is the average pressure over the duration of the run. Run durations were up to $117.2 \mathrm{~h}$. A friction correction of $-10 \%$ and $-7.5 \%$ was used for $1 / 2$ and $3 / 4$ inch assemblies, respectively. In all experiments, the assembly was first overpressurized at room temperature to allow for relaxation of the assembly during heating. The target pressure was achieved when the run reached the target temperature. Upon completion of the experiment, power to the appara- 


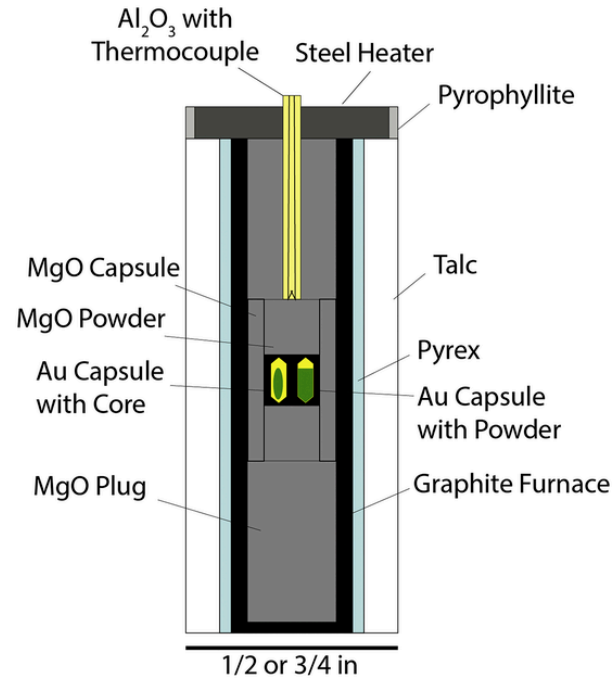

Fig. 1. Schematic of the piston-cylinder assembly. Standard $1 / 2$ or $3 / 4$ inch diameter assemblies were used.

tus was turned off. The experiment was rapidly quenched to $<100{ }^{\circ} \mathrm{C}$ in several seconds by water circulating around the assembly. After quenching, the experimental capsules were mounted in epoxy and polished for analysis.

\section{Analytical techniques}

Major element analysis and X-ray mapping were performed by using a JEOL JXA 8900R electron probe microanalyzer at the Advanced Imaging and Microscopy Laboratory, University of Maryland and a JEOL 8530F field-emission electron probe microanalyzer at the Earth and Planets Laboratory, Carnegie Institution for Science. Wavelength dispersive spectroscopy (WDS) was used to determine the concentration of $\mathrm{Si}, \mathrm{P}, \mathrm{Ti}, \mathrm{Al}, \mathrm{Fe}, \mathrm{Mg}, \mathrm{Mn}, \mathrm{Ca}, \mathrm{Na}, \mathrm{K}, \mathrm{F}$, and $\mathrm{Cl}$ in the experimental run products. The electron beam conditions were an accelerating voltage of $15 \mathrm{kV}$, a current of $5 \mathrm{nA}$ (all run products and some standards) or $20 \mathrm{nA}$ (standards), and a beam size of $1-10 \mu \mathrm{m}$ depending on the phase being analyzed and the size of that phase. Standards included Makaopuhi basalt, microcline, rhodonite, topaz, scapolite, Indian Ocean basalt, Durango apatite, Clear Lake plagioclase, Kakanui hornblende, fayalite, forsterite, fluorapatite, albite, San Carlos olivine, EnAl10 enstatite glass, $\mathrm{TiO}_{2}$, orthoclase, sodalite, Basalt 812, Bear Lake hornblende, magnetite, and $\mathrm{MnO}_{2}$. Elemental mapping was conducted by both wavelength dispersive spectroscopy and energy dispersive spectroscopy (EDS). All major elements that were quantitatively measured were mapped by using EDS. In addition to the EDS maps, Sc was mapped by WDS. The electron beam conditions for mapping were an accelerating voltage of $15 \mathrm{kV}$, a current of $20 \mathrm{nA}$, a dwell time of $20 \mathrm{~ms}$, and a pixel size of $1 \mu \mathrm{m}$.

The abundance or mass fraction of each phase present in the run product assemblage was determined by a constrained linear least-squares method. Inherent in the application of the least-squares method is the assumption that there was no exchange of mass across the capsule walls. Given this assumption, the bulk composition of the run products is equivalent to the bulk composition of the starting material. Thus, the sum of the mass fraction of each run product phase multiplied by the composition of that phase (determined by using WDS), for each major element, should equal the bulk composition of the starting material. In order to perform this calculation, identification of all phases and the composition of those phases, as well as the bulk composition of the starting material is required. To solve these linear least-squares equations the MATLAB function lsqlin was used and was con- strained such that the mass fraction of each phase present is greater than zero and the sum of all mass fractions is equal to one. For all least-squares calculations, iron was assumed to be $\mathrm{FeO}$.

Glass and crystalline run products were analyzed by using laser ablation inductively coupled plasma mass spectrometry (LA-ICP-MS) to determine trace element abundances. LA-ICP-MS was performed using a New Wave UP213 Nd:YAG laser ablation system coupled to a ThermoFisher Element2 ICP-MS at the Plasma Mass Spectrometry Laboratory, University of Maryland. The laser spot sizes were $25 \mu \mathrm{m}(15 \mu \mathrm{m}$ in one case) for the unknowns, $80 \mu \mathrm{m}$ for standards, and $40 \mu \mathrm{m}$ for BHVO2G analyzed as an unknown to evaluate accuracy. The operating conditions for the laser were $7 \mathrm{~Hz}$ and a power of between 2 and $4 \mathrm{~J} \mathrm{~cm}^{-1}$. The standard for all analyses was NIST610 and silicon was used as the internal reference. Data reduction was performed using LAMTRACE (Jackson, 2008).

\section{Results}

\subsection{Phase assemblages and the solidus}

Successful experiments performed at temperatures below $900{ }^{\circ} \mathrm{C}$ exhibited no observable reactions or melting. In all 700 and $800{ }^{\circ} \mathrm{C}$ experiments, no changes in the minerals present in the starting material (amphibole, plagioclase, etc.) were observed. Additionally, the texture at the end of the experiments was unchanged from the original material. The results of the experiments are summarized in Table 1 and Fig. 2. In two experiments performed at $900{ }^{\circ} \mathrm{C}$ (EIP-4 and EIP-7; Evje-Iveland Pegmatite), the run products included glass (Fig. 2A). In experiment EIP-4, glass was found in discreet pockets and the run product assemblage also included amphibole, clinopyroxene, olivine, and minor biotite. The clinopyroxene in experiment EIP-4 is found in the core of run product amphibole. The presence of olivine is probably the result of a short duration temperature spike to $958^{\circ} \mathrm{C}$ during the run, before returning to $900{ }^{\circ} \mathrm{C}$ : it is likely that olivine is not a stable phase at $900{ }^{\circ} \mathrm{C}$. In experiment EIP-7, the glass is intermingled with plagioclase and the run products also included amphibole, clinopyroxene, plagioclase, spinel \pm apatite. Unlike experiment EIP-4, the clinopyroxene is found as a discreet phase. In one experiment (EIP-6), one replicate did not show evidence of melting or subsolidus reactions; the second replicate had minor melting within plagioclase but no other reactions (Fig. 2A). In experiments performed above $900{ }^{\circ} \mathrm{C}$ all run products included a glass (Fig. 2B). In the experiments performed at $950{ }^{\circ} \mathrm{C}$, the minerals in the run products include plagioclase, clinopyroxene, amphibole and spinel (EIP-8), or plagioclase and clinopyroxene (EIP-9). In experiment EIP-8 the glass is intermingled with plagioclase and the clinopyroxene is found within the cores of amphibole. In experiment EIP-9, the glass is found in pockets and the clinopyroxene is present as a discreet phase. Experiment EIP-5 suffered a thermocouple failure that resulted in a runaway temperature at the end of the experiment. The temperature of experiment EIP-5 for the majority of the run $(70.43 \mathrm{~h})$ was $850{ }^{\circ} \mathrm{C}$ and, after failure of the thermocouple, the temperature reached at least $1064{ }^{\circ} \mathrm{C}$ (for $0.16 \mathrm{~h}$ ), estimated by the presence of gold spheres within the experiment, indicating the temperature was approximately the melting point of gold (Fig. 2). The run products in experiment EIP-5 include glass, olivine, and clinopyroxene (as a discreet phase) with residual plagioclase and apatite. The texture of the residual plagioclase indicates that it was dissolving into the melt, but dissolution was halted during quench (Fig. 2). With the failure of experiment EIP-5, constraining the solidus with a great degree of accuracy is difficult. However, the solidus is clearly greater than $800{ }^{\circ} \mathrm{C}$ and in light of the phases present in the run products and the textures in experiment EIP-5, the solidus of the Evje-Iveland amphibolite at $500 \mathrm{MPa}$ in vapor-absent conditions is likely close to $900{ }^{\circ} \mathrm{C}$. 
Table 1

Experimental conditions, run products, and notes.

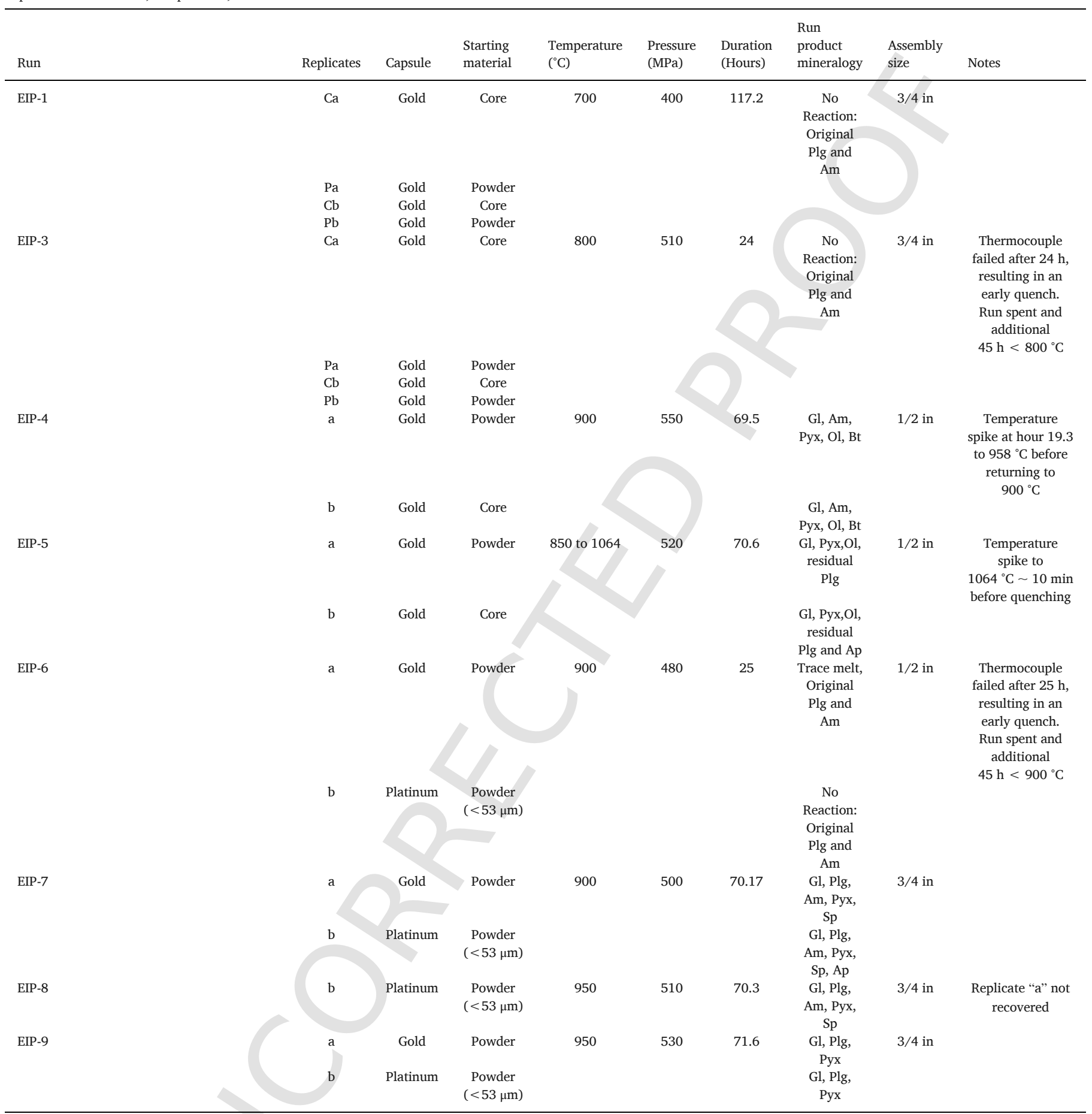

Pressure is the average pressure over the duration of each experiment. $\mathrm{Gl}=$ glass, $\mathrm{Am}=$ amphibole, $\mathrm{Plg}=$ plagioclase, $\mathrm{Ol}=\mathrm{olivine}, \mathrm{Bt}=\mathrm{biotite}, \mathrm{Ap}=\mathrm{apatite}, \mathrm{Sp}=\mathrm{Spinel}$.

\subsection{Major element composition of run products}

\subsubsection{Glass}

The compositions of run product glasses are reported in Table 2 and vary in $\mathrm{SiO}_{2}$ from 47.5 to $65.7 \mathrm{wt} \%$ and plotted on an anhydrous basis (normalized to $100 \%$ ) in Fig. 3 . The glass at the solidus $\left(900{ }^{\circ} \mathrm{C}\right.$ ) is trachyandesitic (Fig. 4). The minor amount of glass in experiment EIP-6a was not analyzed quantitatively due to the small size, but a semi-quantitative EDS analysis suggests that the $\mathrm{SiO}_{2}$ concentration of the glass is $>75 \%$ and the $\mathrm{K}_{2} \mathrm{O}+\mathrm{Na}_{2} \mathrm{O}$ concentration is $\sim 6 \mathrm{wt} \%$. At temperatures between 900 and $950{ }^{\circ} \mathrm{C}$ the glasses are trachyandesitic to 


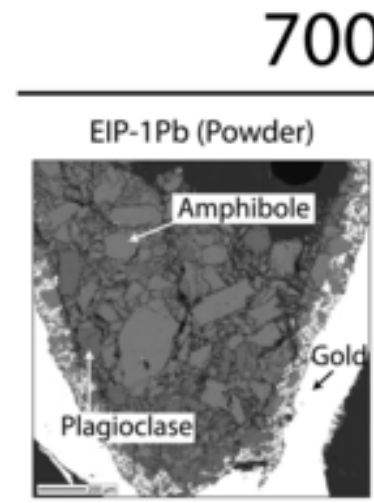

No Reaction

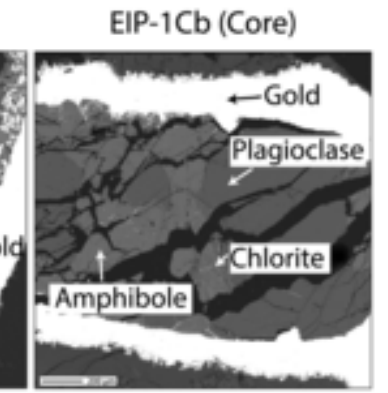

No Reaction $800^{\circ} \mathrm{C}$

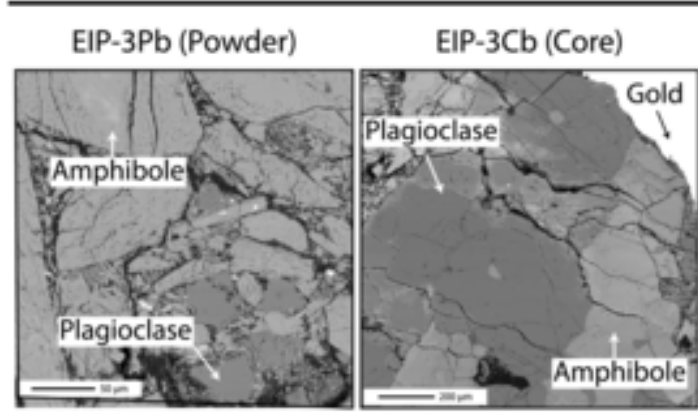

No Reaction

No Reaction

\section{$900^{\circ} \mathrm{C}$}

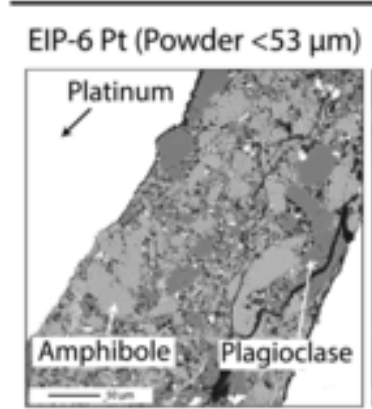

Result: No Reaction
EIP-6 Au (Powder)

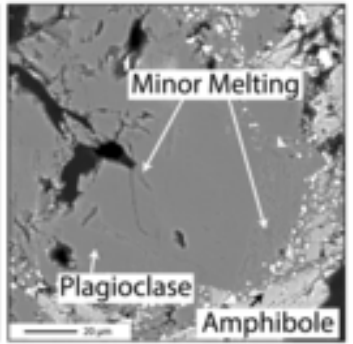

Result: Minor Melting

EIP-4 (Powder)

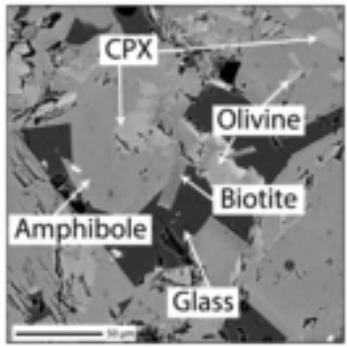

Result: $38 \%$ Melting
EIP-7 Au (Powder)

EIP-7 Pt (Powder $<53 \mu \mathrm{m})$

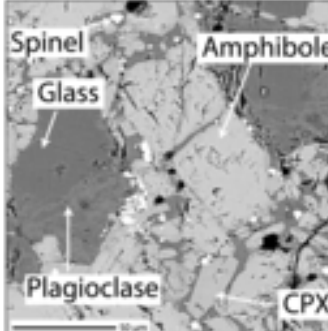

Result: $13 \%$ Melting
Result: $8 \%$ Melting

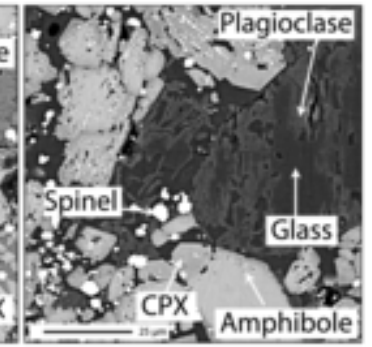

Result: $36 \%$ Melting

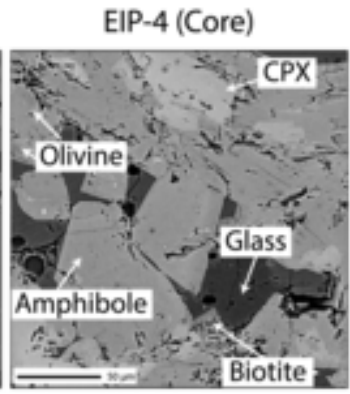

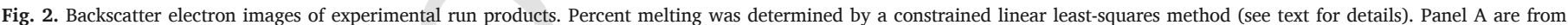
experiments run at 700 to $900^{\circ} \mathrm{C}$. Panel B are from experiments $>900^{\circ} \mathrm{C}$.

dacitic in composition. At temperatures above $950{ }^{\circ} \mathrm{C}$ the glasses are dacitic to basaltic (trachy) andesite. At temperatures approaching the liquidus the glasses are basaltic in composition and approaching the bulk composition of the starting material (Fig. 4). The $\mathrm{Al}_{2} \mathrm{O}_{3}$ and $\mathrm{Na}_{2} \mathrm{O}$ concentration of the run product glasses are also noteworthy. The run product glasses are more aluminous than the starting material with $\mathrm{Al}_{2} \mathrm{O}_{3}$ up to $23 \mathrm{wt} \%$ (Fig. 5) and the ASI (aluminum saturation index; molar $\mathrm{Al}_{2} \mathrm{O}_{3} /\left(\mathrm{Na}_{2} \mathrm{O}+\mathrm{K}_{2} \mathrm{O}+\left(\mathrm{CaO}-1.67 \cdot \mathrm{P}_{2} \mathrm{O}_{5}\right)\right)$ of the melt ranging from 0.62 to 1.91 across the range of melt compositions in different experiments (Table 2). Additionally, the $\mathrm{Na}_{2} \mathrm{O}$ concentration of the glass decreases with decreasing $\mathrm{Al}_{2} \mathrm{O}_{3}$ and near the solidus is greater than $5 \mathrm{wt} \%$ (Fig. 5). These changes in glass composition are primarily the result of variations in run temperature. The temperature of the experiments controls which phases coexist with the melt, and ultimately the proportion of melt generated. For instance, the melting of plagioclase and amphibole results in a more aluminous and sodic melt coexisting with pyroxene, more aluminous amphibole, and less sodic plagioclase.

In addition to variable glass compositions, initial analyses of the glass in experiment EIP-4 at the University of Maryland yielded $\mathrm{Na}_{2} \mathrm{O}$ concentrations of 11 to $12 \mathrm{wt} \%$; however, repeat analyses utilizing the same operating conditions, both at the University of Maryland and at the Earth and Planets Laboratory, prior to and after minor repolishing the sample yielded lower analytical totals and lower $\mathrm{Na}_{2} \mathrm{O}$ concentrations (Table 2). It is likely that between analyses, the glass became hydrated and began to break down, potentially undergoing perlitization. Regardless of the cause of this breakdown, it is clear that the glasses produced at the solidus are both aluminous and sodic.

\subsubsection{Amphibole}

The composition of the starting amphibole are magnesiohornblende. The newly crystallized amphibole in the run products are pargasite and 


\section{$950^{\circ} \mathrm{C}$}

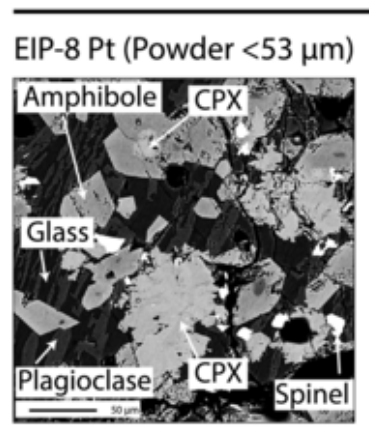

Result: $23 \%$ Melting

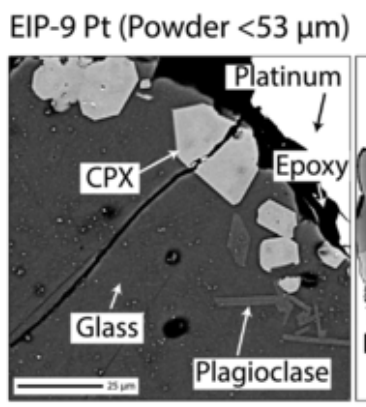

Result: 34\% Melting
EIP-9 Au (Powder)

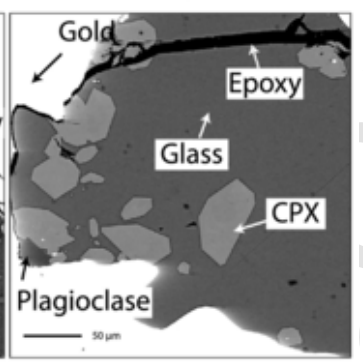

Result: $61 \%$ Melting

\section{0 to $1064^{\circ} \mathrm{C}$}

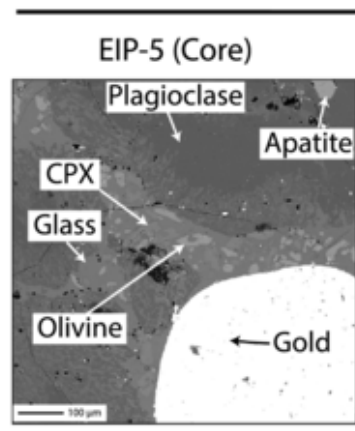

Result: $62 \%$ Melting

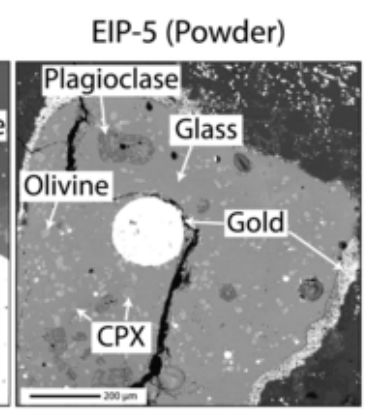

Result: $83 \%$ Melting
Fig. 2. Continued

are more aluminous (11.5 to $17.2 \mathrm{wt} \% \mathrm{Al}_{2} \mathrm{O}_{3}$ ) and sodic (1.71 to $3.18 \mathrm{wt} \% \quad \mathrm{Na}_{2} \mathrm{O}$ ) than the starting amphibole (10.0 wt $\% \quad \mathrm{Al}_{2} \mathrm{O}_{3}$; $1.66 \mathrm{wt} \% \mathrm{Na}_{2} \mathrm{O}$ ) (Table 3; Fig. 6). Additionally, the starting amphibole have $\mathrm{Fe} /(\mathrm{Fe}+\mathrm{Mg})$ of 0.46 , whereas run product amphibole have $\mathrm{Fe} / \mathrm{C}$ $\mathrm{Fe}+\mathrm{Mg}$ ) that are generally lower, ranging from 0.22 to 0.47 . Amphibole from experiment EIP-7 $\left(900{ }^{\circ} \mathrm{C}\right)$ are only slightly more aluminous (11.5 to $12.0 \mathrm{wt} \% \mathrm{Al}_{2} \mathrm{O}_{3}$ ) than the starting amphibole and are the closest in composition to the starting amphibole (Table 3). As temperature increases, the amphibole become increasingly pargasitic.

\subsubsection{Plagioclase}

Plagioclase in the starting material have a composition of $X_{A n} P l$ (defined as the mole fraction of the anorthite component in the plagioclase solid solution) of 0.41 to 0.45 (Table 4 and supplementary files). Generally, the run product plagioclase increase in $X_{A n}^{P l}$ with increasing temperature (Fig. 7); however, the plagioclase compositions are variable and in some cases, two plagioclase compositions coexist. For example, in both replicates of experiment EIP-7 $\left(900{ }^{\circ} \mathrm{C}\right.$ ), plagioclase exists with two distinct compositions, one with moderate $X_{A n} P l$ $\left(0.52\right.$ and 0.56 , respectively) and the other with lower $X_{A n}{ }^{P l}(0.39$ and 0.46 , respectively). The high $X_{A n}{ }^{P l}$ plagioclase represents newly crystallized plagioclase, which falls near the plagioclase solidus (Fig. 7) and the low $X_{A n}{ }^{P l}$ may represent residual plagioclase, which may not have reacted completely. Experiments conducted at $950{ }^{\circ} \mathrm{C}$ yield plagioclase compositions that are broadly consistent with the plagioclase solidus ( $X_{A n}^{P l}$ ranging from 0.55 to 0.66 ; Fig. 7 ). In the highest temperature experiment (EIP-5; $1064{ }^{\circ} \mathrm{C}$ ) plagioclase compositions also vary between replicates; plagioclase composition in one replicate is $X_{A n}{ }^{P l}=$ 0.76 and the other replicate is $X_{A n}^{P l}=0.52$ (Table 4). The large differ- ence in plagioclase composition in experiment EIP-5 is likely due to the kinetics of crystallization and the grain size of the starting material. In this experiment, there was failure of the thermocouple and that resulted in an abrupt increase in temperature and rapid dissolution of the starting plagioclase. As the temperature increased rapidly, the composition of the plagioclase changed and approached equilibrium with the melt, but equilibration of the larger grains was slower than the rate of temperature increase. In replicate EIP-5a the starting material was a powder, with smaller grain size than the core in replicate EIP-5b, and the result was a shorter equilibration time in replicate EIP-5a and higher $X_{A n}{ }^{P l}$ than replicate EIP-5b.

\subsubsection{Pyroxene}

Run product pyroxene is present in all experiments that contain a glass. The run product pyroxene have a composition that plots within the enstatite-ferrosilite-hedenbergite-diopside quadrilateral, and are augite and diopside (Fig. 8). All run product pyroxene are aluminum-rich with between 0.1 and 0.56 aluminum per formula unit (apfu) (Table 5). In four experiments, two discrete pyroxene compositions occur based on their aluminum concentrations (e.g. 0.47 vs 0.56 aluminum apfu in replicate EIP-4a). Generally, the low-aluminum pyroxene are less abundant than the high-aluminum pyroxene.

\subsubsection{Olivine}

Olivine is only present as a run product phase in two experiments: EIP-4 and EIP-5. Run product olivine in experiment EIP-4 $\left(900{ }^{\circ} \mathrm{C}\right.$ ) have $X_{F o}{ }^{O l}$ (defined as the mole fraction of the forsterite $\left(\mathrm{Mg}_{2} \mathrm{SiO}_{4}\right)$ component in the olivine solid solution) that ranges from 0.67 to 0.8 . In replicate EIP-4a, there are coexisting olivine with variable $X_{F o}{ }^{o l}$, one with a 
Table 2

Major element composition of run product glass.

\begin{tabular}{|c|c|c|c|c|c|c|c|c|c|c|c|c|c|c|c|c|c|c|c|c|c|c|c|c|c|c|c|c|c|}
\hline \multirow[t]{2}{*}{ Replicate } & \multicolumn{6}{|c|}{ EIP-4 Early Analysis } & \multicolumn{6}{|l|}{ EIP-4 } & \multicolumn{12}{|l|}{ EIP-5 } & \multicolumn{3}{|l|}{ EIP-8 } & \multicolumn{2}{|l|}{ EIP-9 } \\
\hline & $\mathrm{a}$ & & & $\mathrm{b}$ & & & $\mathrm{a}$ & & & $\mathrm{b}$ & & & $\mathrm{a}$ & & & $\mathrm{b}$ & & & a & & & $\mathrm{b}$ & & & $\mathrm{b}$ & & & $\mathrm{a}$ & \\
\hline $\mathrm{N}$ & 10 & & & 10 & & & 19 & & & 20 & & & 19 & & & 22 & & & 4 & & & 10 & & & 9 & & & 10 & \\
\hline $\mathrm{SiO}_{2}$ & 61.2 & \pm & 0.2 & 59.9 & \pm & 0.3 & 57.3 & \pm & 0.2 & 56.2 & \pm & 0.671 & 47.5 & \pm & 0.2 & 49.4 & \pm & 0.4 & 55.4 & \pm & 0.4 & 62.0 & \pm & 0.5 & 64.7 & \pm & 0.6 & 53.3 & \\
\hline $\mathrm{Al}_{2} \mathrm{O}_{3}$ & 23.9 & \pm & 0.2 & 24.7 & \pm & 0.2 & 21.5 & \pm & 0.1 & 22.8 & \pm & 0.537 & 16.8 & \pm & 0.1 & 16.5 & \pm & 0.2 & 21.6 & \pm & 0.4 & 15.5 & \pm & 0.2 & 14.8 & \pm & 0.4 & 18.23 & \\
\hline $\mathrm{TiO}_{2}$ & 0.05 & \pm & 0.02 & 0.03 & \pm & 0.01 & 0.04 & \pm & 0.01 & 0.2 & \pm & 0.132 & 1.18 & \pm & 0.03 & 0.75 & \pm & 0.04 & 0.32 & \pm & 0.05 & 0.53 & \pm & 0.03 & 0.27 & \pm & 0.01 & 0.62 & \\
\hline $\mathrm{FeO}$ & 1.35 & \pm & 0.03 & 1.00 & \pm & 0.07 & 1.41 & \pm & 0.04 & 1.3 & \pm & 0.371 & 10.7 & \pm & 0.3 & 10.5 & \pm & 0.2 & 4.3 & \pm & 0.2 & 3.1 & \pm & 0.2 & 1.65 & \pm & 0.03 & 7.62 & \\
\hline $\mathrm{MgO}$ & 0.08 & \pm & 0.02 & 0.04 & \pm & 0.01 & 0.18 & \pm & 0.06 & 0.7 & \pm & 0.635 & 5.35 & \pm & 0.09 & 5.0 & \pm & 0.2 & 1.4 & \pm & 0.3 & 2.0 & \pm & 0.3 & 0.63 & \pm & 0.02 & 2.35 & \\
\hline $\mathrm{MnO}$ & 0.08 & \pm & 0.02 & 0.05 & \pm & 0.01 & 0.058 & \pm & 0.005 & 0.1 & \pm & 0.009 & 0.197 & \pm & 0.008 & 0.18 & \pm & 0.01 & 0.08 & \pm & 0.01 & 0.13 & \pm & 0.01 & 0.14 & \pm & 0.01 & 0.19 & \\
\hline $\mathrm{CaO}$ & 0.17 & \pm & 0.02 & 0.28 & \pm & 0.03 & 0.23 & \pm & 0.04 & 0.9 & \pm & 0.559 & 11.49 & \pm & 0.08 & 9.8 & \pm & 0.2 & 1.5 & \pm & 0.2 & 4.5 & \pm & 0.1 & 4.0 & \pm & 0.2 & 5.40 & \\
\hline $\mathrm{Na}_{2} \mathrm{O}$ & 11.6 & \pm & 0.1 & 11.78 & \pm & 0.08 & 5.6 & \pm & 0.2 & 8.4 & \pm & 0.853 & 3.21 & \pm & 0.05 & 3.79 & \pm & 0.09 & 5.7 & \pm & 0.6 & 2.2 & \pm & 0.1 & 1.4 & \pm & 0.2 & 3.55 & \\
\hline $\mathrm{K}_{2} \mathrm{O}$ & 1.68 & \pm & 0.02 & 2.30 & \pm & 0.07 & 1.76 & \pm & 0.02 & 1.9 & \pm & 0.201 & 0.77 & \pm & 0.02 & 0.85 & \pm & 0.04 & 2.9 & \pm & 0.1 & 2.05 & \pm & 0.03 & 1.91 & \pm & 0.04 & 1.71 & \\
\hline $\mathrm{Cl}$ & 0.43 & \pm & 0.01 & 0.32 & \pm & 0.03 & 0.475 & \pm & 0.009 & 0.3 & \pm & 0.033 & 0.054 & \pm & 0.004 & 0.076 & \pm & 0.004 & 0.12 & \pm & 0.02 & 0.110 & \pm & 0.005 & 0.17 & \pm & 0.01 & 0.11 & \\
\hline $\mathrm{F}$ & 0.06 & \pm & 0.03 & 0.14 & \pm & 0.05 & 0.08 & \pm & 0.01 & 0.1 & \pm & 0.000 & 0.29 & \pm & 0.04 & 0.28 & \pm & 0.03 & & d. to 0 & & 0.12 & \pm & 0.01 & 0.06 & \pm & 0.01 & 0.07 & \\
\hline $\mathrm{P}_{2} \mathrm{O}_{5}$ & 0.15 & \pm & 0.03 & 0.16 & \pm & 0.02 & 0.25 & \pm & 0.03 & 0.3 & \pm & 0.023 & 0.11 & \pm & 0.02 & 0.11 & \pm & 0.02 & 0.08 & \pm & 0.03 & 0.17 & \pm & 0.01 & 0.38 & \pm & 0.02 & 0.24 & \\
\hline$-(\mathrm{F}, \mathrm{Cl})=\mathrm{O}$ & & 0.1 & & & 0.1 & & & 0.1 & & & 0.1 & & & 0.1 & & & 0.1 & & & 0.06 & & & 0.08 & & & 0.06 & & & 0 \\
\hline Total & 100.7 & \pm & 0.3 & 100.5 & \pm & 0.4 & 88.8 & \pm & 0.3 & 92.9 & \pm & 1.5 & 97.5 & \pm & 0.4 & 97.0 & \pm & 0.6 & 93.4 & \pm & 0.9 & 92.4 & \pm & 0.6 & 90.0 & \pm & 0.8 & 93.3 & \\
\hline ASI & & 1.14 & & & 1.11 & & & 1.91 & & & 1.34 & & & 0.62 & & & 0.66 & & & 1.41 & & & 1.13 & & & 1.32 & & & 1. \\
\hline
\end{tabular}

b.d. is below detection. Uncertainty is the standard deviation of the mean $\left(1 \sigma_{\mathrm{m}}\right)$. "Early Analysis" indicates analyses of glass prior to breakdown and perlitization 


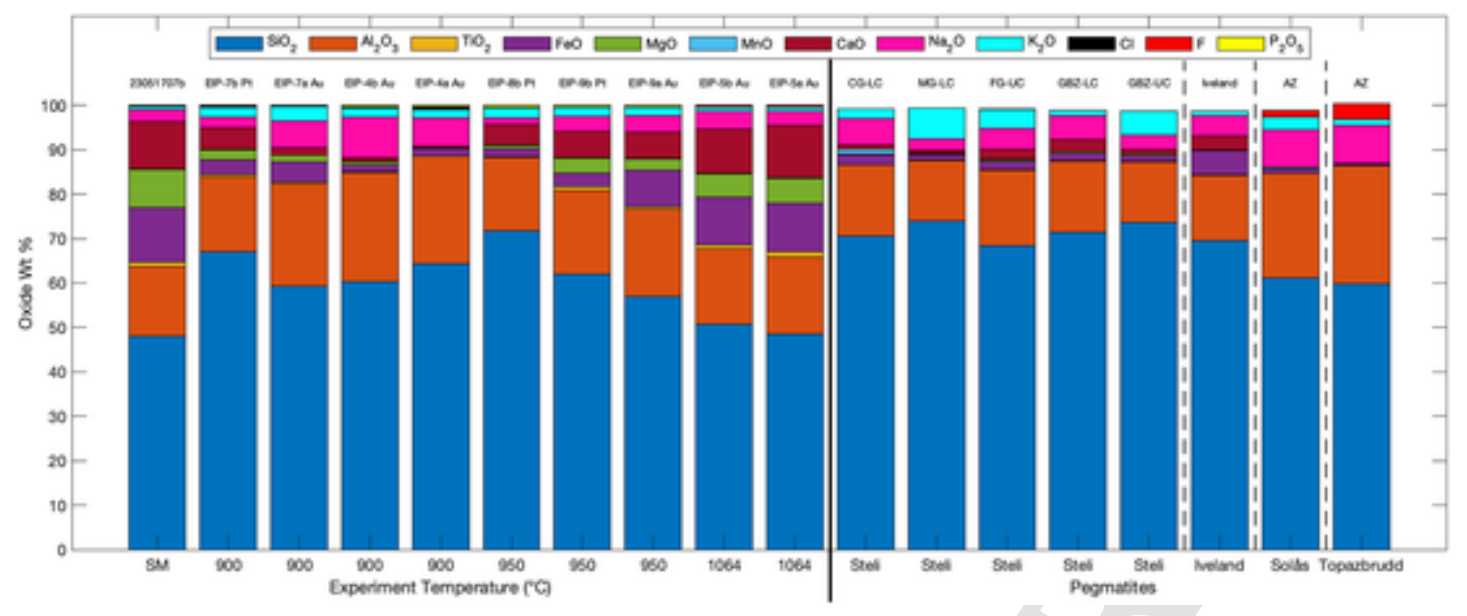

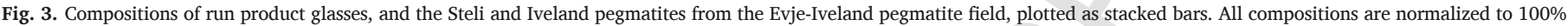

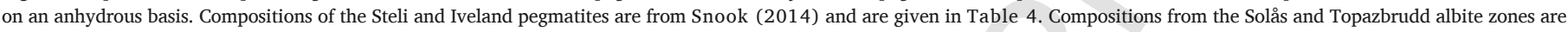

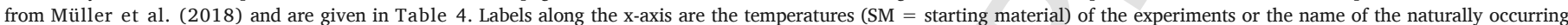

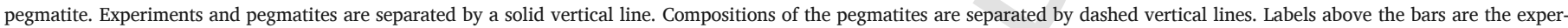

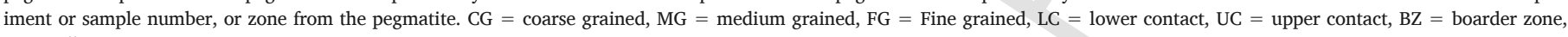
$\mathrm{AZ}=$ albite zone.

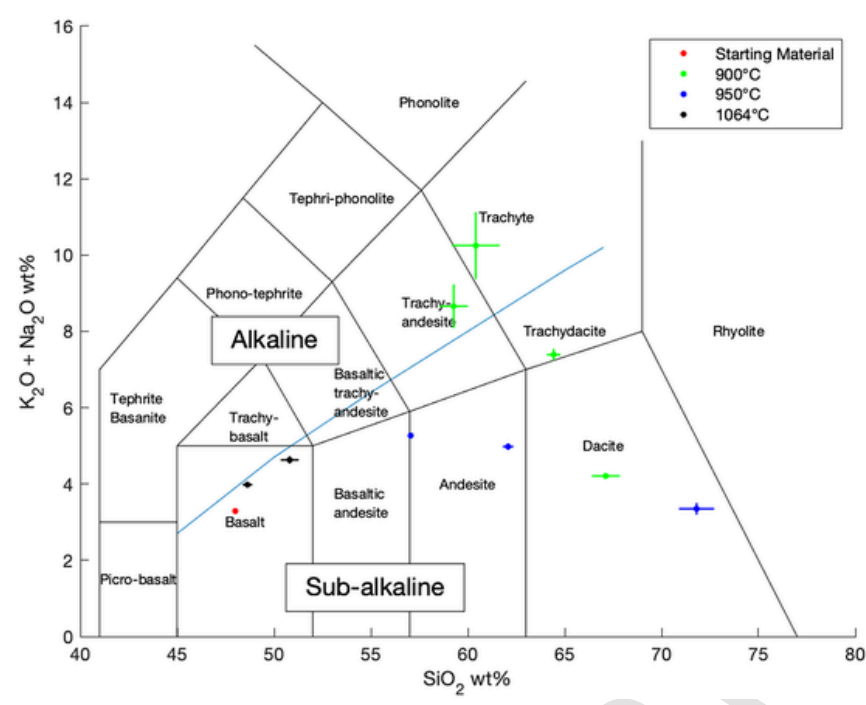

Fig. 4. Total alkali vs silica (TAS) diagram of run product glass and starting material compositions. Uncertainty is reported as the standard deviation of the mean $\left(1 \sigma_{\mathrm{m}}\right)$.

$X_{F o}{ }^{O l}=0.80$ and one with a $X_{F o}{ }^{o l}=0.67$; whereas in replicate EIP-4b the olivine have $X_{F o}{ }^{O l}=0.74$ (Table 6). The low $X_{F o}{ }^{O l}$ olivine are less abundant than the high $X_{F o}$ ol in replicate EIP-4a. As mentioned above the olivine in the experiment are likely the result of a short duration temperature spike to above $950{ }^{\circ} \mathrm{C}$. Upon cooling to the run temperature $\left(950^{\circ} \mathrm{C}\right)$ after this spike the olivine attempts to re-equilibrate resulting in two olivine compositions. In experiment EIP-5 $\left(1064{ }^{\circ} \mathrm{C}\right)$, where olivine did not undergo re-equilibration at a lower temperature, the olivine have $X_{F o}{ }^{o l}$ that range from 0.63 to 0.67 .

\subsubsection{Miscellaneous crystalline phases}

There are several additional crystalline phases that occur as minor phases in the starting material and as run products in a small number of experiments. These phases include biotite, oxides, and apatite. Biotite is only present in experiment EIP- $4\left(900^{\circ} \mathrm{C}\right)$. The biotite have a $X_{P h l}{ }^{B t}$ of 0.74 to 0.77 (Table 7 ), where the $X_{P h l}{ }^{B t}$ (defined as the fraction of magnesium in the octahedral site) is the mole fraction of the phlogopite component in the biotite solid solution. The limited occurrence of biotite in the run products is likely due to the minor concen-

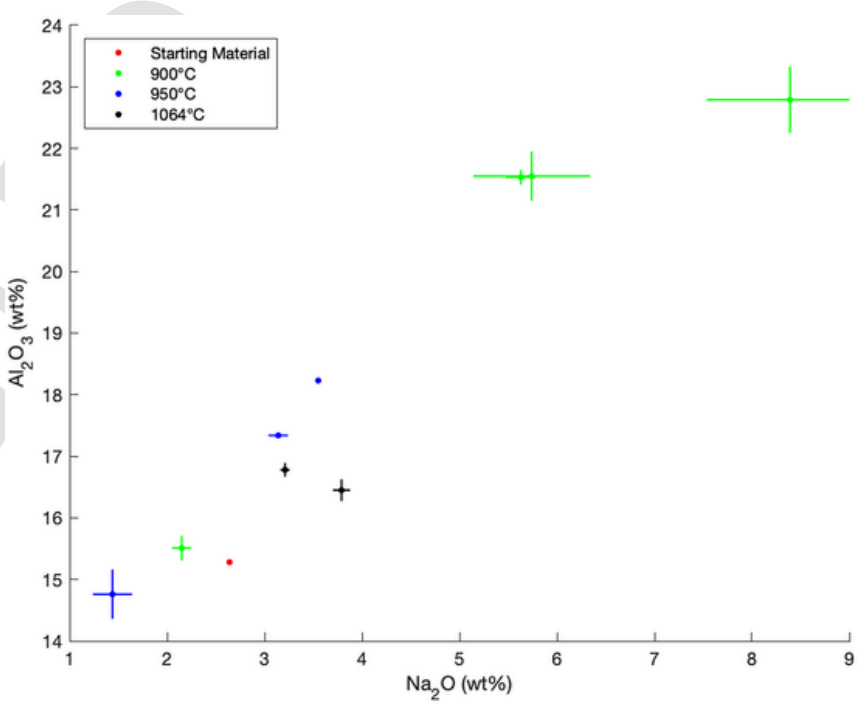

Fig. 5. $\mathrm{Al}_{2} \mathrm{O}_{3}$ vs $\mathrm{Na}_{2} \mathrm{O}$ (wt\%) plot for run product glasses and starting material. Uncertainty is the standard deviation of the mean $\left(1 \sigma_{\mathrm{m}}\right)$.

tration of $\mathrm{K}_{2} \mathrm{O}(0.65 \mathrm{wt} \%)$ in the starting material. The starting material contains ilmenite (Table 8); however, oxides are absent in the majority of experimental run products, occurring only in experiments EIP-7 and EIP-8. In replicates EIP-7a and EIP-8b the oxides are titanium-rich magnetite and in replicate EIP-7b the oxides are iron-rich ulvöspinel (Table 8). Apatite occurs in the starting material and as a residual unreacted phase in replicate EIP-5a, whereas newly crystallized apatite is only found in replicate EIP-7b (Table 9).

\subsection{Proportion of phases and mass balance}

The results of the least-squares calculations are given in Table 10 and Fig. 9 along with the residuals of the fits in Table 11. The residual is the difference between the concentration of a given major oxide in the starting material and the estimation of the concentration of that oxide from the least-squares calculation. The least-squares calculation has a good fit (residuals are typically below $1 \%$ for each major element) for the starting materials and all of the replicates in experiments EIP-5 and EIP-7. For replicates in experiment EIP-4 and replicates EIP- 
Table 3

Major element composition and formulas of starting and run product amphibole.

\begin{tabular}{|c|c|c|c|c|c|c|c|c|c|c|c|c|c|c|c|c|c|c|}
\hline Replicate & \multicolumn{3}{|c|}{ 23051707b } & \multicolumn{6}{|l|}{ EIP-4 } & \multicolumn{6}{|l|}{ EIP-7 } & \multicolumn{3}{|l|}{ EIP-8 } \\
\hline & & & & \multicolumn{3}{|l|}{$\mathrm{a}$} & \multicolumn{3}{|l|}{$\mathrm{b}$} & \multicolumn{3}{|l|}{ a } & \multicolumn{3}{|l|}{$\mathrm{b}$} & \multicolumn{3}{|l|}{$\mathrm{b}$} \\
\hline $\mathrm{N}$ & \multicolumn{3}{|l|}{10} & \multicolumn{3}{|l|}{23} & \multicolumn{3}{|l|}{19} & \multicolumn{3}{|l|}{10} & \multicolumn{3}{|l|}{9} & \multicolumn{3}{|l|}{8} \\
\hline $\mathrm{SiO}_{2}$ & 44.9 & \pm & 0.3 & 40.6 & \pm & 0.3 & 41.1 & \pm & 0.3 & 44.7 & \pm & 0.1 & 44.3 & \pm & 0.2 & 41.0 & \pm & 0.3 \\
\hline $\mathrm{Al}_{2} \mathrm{O}_{3}$ & 10.0 & \pm & 0.3 & 17.1 & \pm & 0.4 & 17.2 & \pm & 0.4 & 11.5 & \pm & 0.1 & 12.0 & \pm & 0.2 & 15.0 & \pm & 0.3 \\
\hline $\mathrm{TiO}_{2}$ & 1.12 & \pm & 0.05 & 1.7 & \pm & 0.2 & 1.3 & \pm & 0.2 & 1.20 & \pm & 0.02 & 1.22 & \pm & 0.03 & 2.18 & \pm & 0.06 \\
\hline $\mathrm{FeO}$ & 17.1 & \pm & 0.2 & 8.7 & \pm & 0.2 & 8.0 & \pm & 0.2 & 16.9 & \pm & 0.2 & 17.6 & \pm & 0.2 & 9.5 & \pm & 0.2 \\
\hline $\mathrm{MgO}$ & 11.0 & \pm & 0.1 & 14.9 & \pm & 0.1 & 15.7 & \pm & 0.1 & 11.6 & \pm & 0.1 & 11.0 & \pm & 0.1 & 17.3 & \pm & 0.3 \\
\hline $\mathrm{MnO}$ & 0.29 & \pm & 0.02 & 0.145 & \pm & 0.008 & 0.14 & \pm & 0.01 & 0.269 & \pm & 0.006 & 0.27 & \pm & 0.01 & 0.21 & \pm & 0.02 \\
\hline $\mathrm{CaO}$ & 11.59 & \pm & 0.06 & 12.8 & \pm & 0.4 & 12.4 & \pm & 0.1 & 11.82 & \pm & 0.02 & 11.73 & \pm & 0.04 & 11.7 & \pm & 0.1 \\
\hline $\mathrm{Na}_{2} \mathrm{O}$ & 1.66 & \pm & 0.04 & 3.01 & \pm & 0.09 & 3.18 & \pm & 0.05 & 1.71 & \pm & 0.03 & 1.82 & \pm & 0.07 & 2.72 & \pm & 0.03 \\
\hline $\mathrm{K}_{2} \mathrm{O}$ & 0.57 & \pm & 0.03 & 0.65 & \pm & 0.03 & 0.66 & \pm & 0.02 & 0.62 & \pm & 0.01 & 0.61 & \pm & 0.03 & 0.39 & \pm & 0.01 \\
\hline $\mathrm{Cl}$ & \multicolumn{3}{|c|}{ n.a. } & 0.023 & \pm & 0.002 & 0.020 & \pm & 0.002 & 0.07 & \pm & 0.01 & 0.077 & \pm & 0.006 & 0.026 & \pm & 0.005 \\
\hline $\mathrm{F}$ & & n.a. & & 0.30 & \pm & 0.03 & 0.22 & \pm & 0.02 & 0.07 & \pm & 0.02 & \multicolumn{3}{|c|}{ b.d. to 0.1} & & 1. to 0 & \\
\hline $\mathrm{P}_{2} \mathrm{O}_{5}$ & 0.03 & \pm & 0.01 & 0.051 & \pm & 0.009 & 0.05 & \pm & 0.01 & & to 0 & & 0.06 & \pm & 0.02 & 0.07 & \pm & 0.01 \\
\hline$-(\mathrm{F}, \mathrm{Cl})=\mathrm{O}$ & & 0 & & & 0.1 & & & 0.1 & & & 0.02 & & & 0.06 & & & 0.03 & \\
\hline Total & 98.2 & \pm & 0.5 & 99.8 & \pm & 0.7 & 99.9 & \pm & 0.6 & 100.4 & \pm & 0.3 & 100.8 & \pm & 0.4 & 100.2 & \pm & 0.5 \\
\hline $\mathrm{H}_{2} \mathrm{O}$ & 1.77 & \pm & 0.01 & 1.59 & \pm & 0.04 & 1.72 & \pm & 0.05 & 1.76 & \pm & 0.01 & 1.74 & \pm & 0.01 & 1.62 & \pm & 0.09 \\
\hline & & & & & & & & Form & & & & & & & & & & \\
\hline & & & & & & & Tetrahe & al ( $\mathrm{T}$ & te) cation & & & & & & & & & \\
\hline $\mathrm{Si}$ & 6.68 & \pm & 0.04 & 5.78 & \pm & 0.05 & 5.82 & \pm & 0.05 & 6.47 & \pm & 0.01 & 6.43 & \pm & 0.02 & 5.76 & \pm & 0.04 \\
\hline $\mathrm{Al}$ & 1.32 & \pm & 0.04 & 2.21 & \pm & 0.05 & 2.17 & \pm & 0.05 & 1.53 & \pm & 0.01 & 1.57 & \pm & 0.03 & 2.23 & \pm & 0.04 \\
\hline $\mathrm{P}$ & 0.0034 & \pm & 0.0009 & 0.006 & \pm & 0.001 & 0.007 & \pm & 0.002 & & to 0 & & 0.007 & \pm & 0.002 & 0.008 & \pm & 0.001 \\
\hline Total & 8.00 & \pm & 0.06 & 8.00 & \pm & 0.07 & 8.00 & \pm & 0.08 & 8.00 & \pm & 0.02 & 8.00 & \pm & 0.03 & 8.00 & \pm & 0.05 \\
\hline & & & & & & & Octahe & al (C & te) cation & & & & & & & & & \\
\hline $\mathrm{Al}$ & 0.42 & \pm & 0.02 & 0.66 & \pm & 0.02 & 0.70 & \pm & 0.02 & 0.44 & \pm & 0.02 & 0.490 & \pm & 0.009 & 0.26 & \pm & 0.02 \\
\hline $\mathrm{Ti}$ & 0.125 & \pm & 0.006 & 0.18 & \pm & 0.02 & 0.14 & \pm & 0.02 & 0.131 & \pm & 0.003 & 0.133 & \pm & 0.004 & 0.230 & \pm & 0.006 \\
\hline $\mathrm{Fe}^{3+}$ & 0.06 & \pm & 0.05 & 0.24 & \pm & 0.02 & 0.20 & \pm & 0.01 & 0.23 & \pm & 0.02 & 0.18 & \pm & 0.02 & 0.70 & \pm & 0.03 \\
\hline $\mathrm{Fe}^{2+}$ & 2.07 & \pm & 0.03 & 0.80 & \pm & 0.05 & 0.75 & \pm & 0.05 & 1.82 & \pm & 0.02 & 1.95 & \pm & 0.03 & 0.41 & \pm & 0.03 \\
\hline $\mathrm{Mg}$ & 2.45 & \pm & 0.03 & 3.16 & \pm & 0.03 & 3.32 & \pm & 0.03 & 2.51 & \pm & 0.02 & 2.39 & \pm & 0.03 & 3.62 & \pm & 0.05 \\
\hline $\mathrm{Mn}$ & 0.036 & \pm & 0.002 & 0.017 & \pm & 0.001 & 0.017 & \pm & 0.001 & 0.033 & \pm & 0.001 & 0.034 & \pm & 0.002 & 0.025 & \pm & 0.002 \\
\hline Total & 5.15 & \pm & 0.07 & 5.05 & \pm & 0.06 & 5.11 & \pm & 0.07 & 5.17 & \pm & 0.04 & 5.18 & \pm & 0.04 & 5.24 & \pm & 0.07 \\
\hline & & & & & & & & 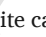 & ions & & & & & & & & & \\
\hline $\mathrm{Ca}$ & 1.846 & \pm & 0.008 & 1.95 & \pm & 0.05 & 1.89 & \pm & 0.01 & 1.835 & \pm & 0.003 & 1.823 & \pm & 0.005 & 1.76 & \pm & 0.02 \\
\hline $\mathrm{Na}$ & 0.15 & \pm & 0.01 & 0.05 & \pm & 0.03 & 0.11 & \pm & 0.01 & 0.165 & \pm & 0.007 & 0.18 & \pm & 0.02 & 0.24 & \pm & 0.01 \\
\hline Total & 2.00 & \pm & 0.01 & 2.00 & \pm & 0.06 & 2.00 & \pm & 0.02 & 2.000 & \pm & 0.008 & 2.00 & \pm & 0.02 & 2.00 & \pm & 0.02 \\
\hline A site cations & & & & & & & & & & & & & & & & & & \\
\hline $\mathrm{Na}$ & 0.32 & \pm & 0.01 & 0.78 & \pm & 0.03 & 0.76 & \pm & 0.01 & 0.314 & \pm & 0.007 & 0.33 & \pm & 0.02 & 0.50 & \pm & 0.01 \\
\hline $\mathrm{K}$ & 0.107 & \pm & 0.005 & 0.119 & \pm & 0.005 & 0.119 & \pm & 0.003 & 0.114 & \pm & 0.003 & 0.113 & \pm & 0.005 & 0.071 & \pm & 0.002 \\
\hline Total & 0.43 & \pm & 0.01 & 0.90 & \pm & 0.03 & 0.88 & \pm & 0.01 & 0.428 & \pm & 0.008 & 0.45 & \pm & 0.02 & 0.573 & \pm & 0.007 \\
\hline Hydroxyl site & & & & & & & & & & & & & & & & & & \\
\hline $\mathrm{Cl}$ & & n.a. & & 0.0056 & \pm & 0.0004 & 0.0047 & \pm & 0.0005 & 0.017 & \pm & 0.002 & 0.019 & \pm & 0.001 & 0.006 & \pm & 0.001 \\
\hline $\mathrm{F}$ & & n.a. & & 0.13 & \pm & 0.01 & 0.095 & \pm & 0.009 & 0.030 & \pm & 0.008 & & to 0 & & & d. 0. & \\
\hline $\mathrm{OH}$ & 1.75 & \pm & 0.01 & 1.49 & \pm & 0.04 & 1.61 & \pm & 0.05 & 1.680 & \pm & 0.008 & 1.66 & \pm & 0.01 & 1.48 & \pm & 0.01 \\
\hline Total & 1.75 & \pm & 0.01 & 1.63 & \pm & 0.04 & 1.71 & \pm & 0.05 & 1.73 & \pm & 0.01 & 1.72 & \pm & 0.01 & 1.51 & \pm & 0.01 \\
\hline $\mathrm{Fe} /(\mathrm{Fe}+\mathrm{Mg})$ & 0.46 & \pm & 0.01 & 0.25 & \pm & 0.01 & 0.22 & \pm & 0.01 & 0.45 & \pm & 0.01 & 0.47 & \pm & 0.01 & 0.23 & \pm & 0.01 \\
\hline
\end{tabular}

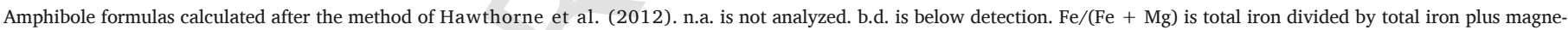
sium. Uncertainty is the standard deviation of the mean $\left(1 \sigma_{\mathrm{m}}\right)$.

$8 \mathrm{~b}$ and EIP-9a, there is a poor fit for several oxides ( $\mathrm{FeO}$, and $\mathrm{MgO}$ in experiment EIP-4; $\mathrm{TiO}_{2}$ and $\mathrm{FeO}$ in replicate EIP-8b; $\mathrm{SiO}_{2}, \mathrm{FeO}$, and $\mathrm{CaO}$ in replicate EIP-9a), but for most of the major elements the residual is generally less than $2 \%$ and often less than $1 \%$. The sum of the squares for replicate EIP-9b would indicate a poor fit, but on examination of the residuals, the goodness of fit is dominated by the residual for $\mathrm{FeO}, \mathrm{CaO}$, and $\mathrm{SiO}_{2}$, whereas the residual for all the other oxides is less than $1 \%$. The large residual for $\mathrm{FeO}$ is likely due to iron loss to the platinum capsule (Table 2). The least-squares technique does not account for this iron loss and therefore underestimates the proportion of glass and overestimates the proportion of pyroxene in the experiment.
If the replicate EIP-9a (gold capsule) is compared to the replicate EIP-9b (platinum capsule) the SSQ (sum of squares) for replicate EIP-9a is $\sim 1 /$ 3 that of EIP-9b. This also occurs in replicates EIP-7b and EIP-8b, but to a lesser extent; the SSQ for the replicate EIP-7a (gold capsule) is $\sim 1 / 2$ of replicate EIP-7b (platinum capsule). Thus, it is assumed that the replicates performed in a gold capsule are more accurate representations of the absolute mineral proportions.

Examining the results of the least-squares calculations (Table 10 and Fig. 9), the proportion of glass present: at $900{ }^{\circ} \mathrm{C}$ is between $\sim 10$ and $40 \%$; at $950{ }^{\circ} \mathrm{C}$ is $\sim 20$ to $60 \%$; and above $1000{ }^{\circ} \mathrm{C}$ is 60 to $80 \%$. At $900{ }^{\circ} \mathrm{C}$, pyroxene begins to crystallize $(\sim 1 \%)$ at the expense of amphi- 


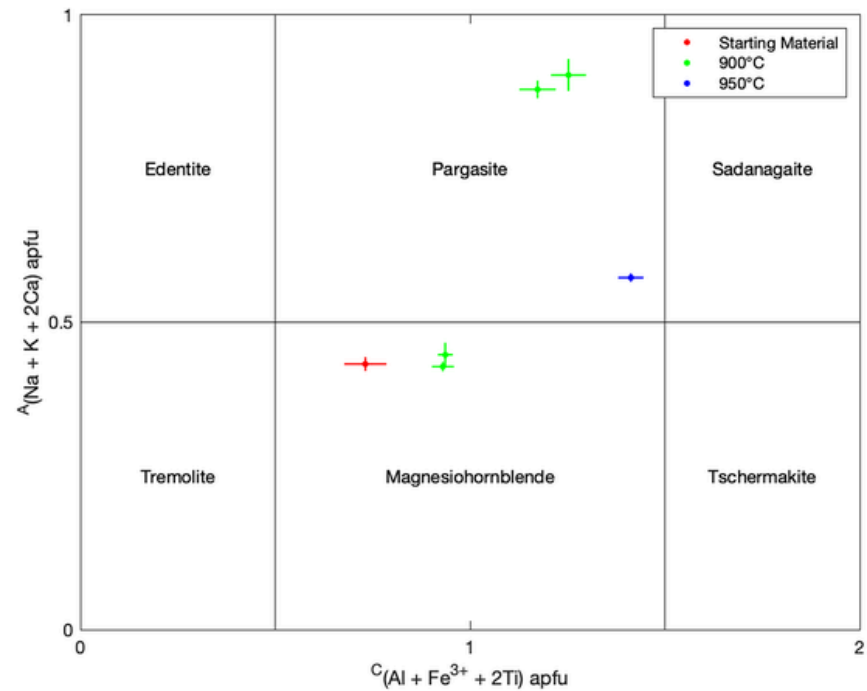

Fig. 6. Plot of amphibole compositions for run products and starting material. Fields from Hawthorne et al. (2012). The $y$-axis is the $(\mathrm{Na}+\mathrm{K}+2 \mathrm{Ca})$ in the A site. The $\mathrm{x}$ - axis is $\left(\mathrm{Al}+\mathrm{Fe}^{3+}+2 \mathrm{Ti}\right)$ in the $\mathrm{C}$ (octahedral) site. Uncertainty is the standard deviation of the mean $\left(1 \sigma_{\mathrm{m}}\right)$.

bole and increases to 30 to $40 \%$ between 900 and $950{ }^{\circ} \mathrm{C}$. Pyroxene begins to disappear at temperatures above $1000{ }^{\circ} \mathrm{C}$. The amount of amphibole decreases with increasing temperature and ultimately disappears as the temperature approaches $950{ }^{\circ} \mathrm{C}$. Olivine is only stable at temperatures greater than $950{ }^{\circ} \mathrm{C}$ (with the exception of experiment EIP-4, which was the result of a temperature spike to $958{ }^{\circ} \mathrm{C}$ ). The presence of biotite, oxides, and apatite is not consistent between experiments and may reflect heterogeneities in the starting material, level of exposure in the mounted run products, or in the case of biotite, low concentrations of primary constituents in the starting material (i.e. $\mathrm{K}_{2} \mathrm{O}$ in the starting material may not be sufficient to saturate a melt with biotite). These phases are visible in the backscatter electron images (Fig. 2), but are predicted to be significantly less than $1 \%$ by the least-squares calculation in most cases. In the case of the oxides, the effect of iron loss to the capsule may result in the stabilization of titanium-rich spinel (e.g. replicate EIP-7b).

\subsection{Approach to equilibrium}

In order to assess equilibrium, two techniques were utilized: replicate experiments and experiments with different physical forms of the starting materials (cores, powdered, and powdered and sieved). Run products were compared from experiments at a given temperature. Replicates in experiments are comparable in terms of composition of run products and mass percent of those run products regardless of the physical form of the starting material. There are differences among experiments performed at the same temperature; however, these differences can generally be explained by variations in temperature for short durations during the run (see comments and discussion of experiment EIP-4) or small temperature gradients within the piston-cylinder assembly. In several experiments, there is a bimodal distribution of pyroxene and plagioclase compositions; however, one composition typically dominates. Further, the presence of zoning of pyroxene and amphibole may not suggest disequilibrium and may be the result of growth along different crystallographic faces (i.e. sector zoning in amphibole). Similarly, for experiments performed at $950{ }^{\circ} \mathrm{C}$ (experiments EIP-8 and -9), the compositional differences of the run products between replicates is the result of the choice of capsule material and the loss of iron to the platinum capsule. Thus, it can be concluded that the experiments approach equilibrium.

\subsection{Elemental mapping}

WDS and EDS maps for $\mathrm{Al}, \mathrm{Ca}, \mathrm{Na}, \mathrm{Mg}$, and Sc are presented in Fig. 10. These maps illustrate a variety of textural and compositional characteristics of the run products. Amphibole in experiments EIP-4 and EIP-8 are sector zoned, whereas amphibole in experiment EIP-7 are relatively unzoned. The lack of zoning in EIP-7 may be a result of the lower-degree partial melting, due to slightly lower temperature or slower reaction rate, such that the composition of the amphibole does not change enough to produce zoning in the amphibole. The sector zoning is most visible in the aluminum maps, but is also present in the magnesium and silicon maps, which is consistent with a Tschermak exchange (i.e. $\mathrm{Mg}+\mathrm{Si}=2 \mathrm{Al}$ ). The maps also highlight the occurrence of pyroxene in amphibole cores, as well as the presence of both high- and low-aluminum pyroxenes (Table 5; Fig. 10b). These high- and low-aluminum pyroxenes are also zoned with respect to magnesium (Fig. 10b) and silicon (Table 5). Plagioclase, when present, forms bands intermingled within the glass and zonation is not apparent. The exception is residual plagioclase in experiment EIP-5 (Fig. 10a). The plagioclase is heterogeneous in composition and has lower sodium and higher calcium in the rim compared to the core: the interpretation is that the rims are dissolving and forming melt. It is also evident from the elemental maps that olivine occurs within amphibole and as a discreet phase above $1000{ }^{\circ} \mathrm{C}$. In these high-temperature experiments, the olivine exhibit magnesium and iron zoning (Fig. 10b). The glass in experiments EIP-4 and EIP-7 are also zoned, whereas all other glasses are homogeneous. The zonation in the melt is primarily reflected in concentrations of sodium and aluminum. Additionally, in experiment EIP-4 low sodium spots are visible within the glass, which has broken down and become hydrated (see above) and may be the result of sodium diffusion away from the electron beam. As noted above, the results of early analyses of glasses from experiment EIP-4 are consistent with the glass being anhydrous with no evidence of breakdown (Table 2). The elemental maps were performed after repolishing and WDS analyses, and the breakdown is visible at a deeper level within the glass (Fig. 10a). Another notable result of the mapping is the distribution of scandium among the phases. In all experiments, the glass has the lowest count rate for scandium and thus likely has the lowest abundance of scandium, except for plagioclase where the abundance is roughly equal. The platinum and gold capsules, although not run products, have the highest count rate for scandium. However, in the case of the gold and platinum a higher count rate does not correlate to a higher concentration. The elevated number of counts is due to a high background. For example, the background count rate on a platinum standard is $\sim 100$ counts, whereas the background count rate on a basalt standard is $\sim 20$ counts. The total number of counts for scandium on the gold and platinum capsules is approximately equal to that of the background, and thus the capsule material contains scandium below detection of the EPMA. It should be noted that the number of counts for scandium on the run products (pyroxene, amphibole, etc.) is above background and has been analyzed by LA-ICP-MS. The oxide phases, where present, have the highest relative abundance of scandium of the run products. Pyroxene and amphibole have the next highest scandium concentration, which is slightly higher than the scandium concentration in olivine.

\subsection{Trace elements}

The trace element concentrations are presented in Table 12 and the supplementary files. The run product glasses from experiments with low degrees of partial melting (experiments EIP-4 and EIP-7) have trace elements which are often below the detection limit of the ICP-MS. As the glass reaches $>40$ mass\% (replicate EIP-9a and experiment EIP-5) 
Table 4

Major element composition of run product plagioclase.

Expand

\begin{tabular}{|c|c|c|c|c|c|c|c|c|c|c|c|c|c|c|c|c|c|c|c|c|c|c|c|c|c|}
\hline \multirow[t]{2}{*}{ Replicate } & \multicolumn{3}{|c|}{$23051707 \mathrm{~b}$} & \multicolumn{6}{|l|}{ EIP-5 } & \multicolumn{10}{|l|}{ EIP-7 } & \multicolumn{3}{|l|}{ EIP-8 } & \multicolumn{3}{|l|}{ EIP-9 } \\
\hline & & & & a & & & $\mathrm{b}$ & & & a & & & a & & & $\mathrm{b}$ & & & $\mathrm{b}$ & $\mathrm{b}$ & & & $\mathrm{a}$ & & \\
\hline $\mathrm{N}$ & 8 & & & 10 & & & 8 & & & 7 & & & 3 & & & 6 & & & 1 & 7 & & & 3 & & \\
\hline $\mathrm{SiO}_{2}$ & 57.4 & \pm & 0.2 & 49.2 & \pm & 0.4 & 55 & \pm & 1 & 57.6 & \pm & 0.7 & 54 & \pm & 1 & 56.7 & \pm & 0.3 & 53.5 & 54.7 & \pm & 0.2 & 53.7 & \pm & 0.4 \\
\hline $\mathrm{Al}_{2} \mathrm{O}_{3}$ & 26.7 & \pm & 0.1 & 30.4 & \pm & 0.8 & 27.4 & \pm & 0.5 & 27.0 & \pm & 0.8 & 29.8 & \pm & 0.1 & 28.0 & \pm & 0.2 & 28.6 & 27.9 & \pm & 0.4 & 28.8 & \pm & 0.9 \\
\hline $\mathrm{TiO}_{2}$ & 0.03 & \pm & 0.01 & 0.17 & \pm & 0.06 & 0.08 & \pm & 0.04 & 0.04 & \pm & 0.02 & 0.05 & \pm & 0.02 & 0.04 & \pm & 0.01 & 0.09 & 0.06 & \pm & 0.01 & 0.07 & \pm & 0.05 \\
\hline $\mathrm{FeO}$ & 0.06 & \pm & 0.02 & 2.1 & \pm & 0.5 & 0.7 & \pm & 0.5 & 0.8 & \pm & 0.2 & 0.70 & \pm & 0.02 & 0.30 & \pm & 0.02 & 0.97 & 0.97 & \pm & 0.07 & 0.9 & \pm & 0.3 \\
\hline $\mathrm{MgO}$ & 0.01 & \pm & 0.00 & 0.7 & \pm & 0.3 & 0.3 & \pm & 0.3 & 0.06 & \pm & 0.04 & 0.047 & \pm & 0.007 & & 1. to 0. & & 0.3 & 0.1 & \pm & 0.0 & 0.2 & \pm & 0.1 \\
\hline $\mathrm{MnO}$ & 0.03 & \pm & 0.01 & 0.04 & \pm & 0.01 & 0.07 & \pm & 0.02 & 0.02 & \pm & 0.01 & & b.d. & & & 1. to 0. & 02 & b.d. & 0.039 & \pm & 0.007 & & d. to 0.0 & \\
\hline $\mathrm{CaO}$ & 8.6 & \pm & 0.1 & 14.9 & \pm & 0.3 & 10.1 & \pm & 0.7 & 7.9 & \pm & 0.8 & 11.6 & \pm & 0.2 & 9.7 & \pm & 0.3 & 12.5 & 11.1 & \pm & 0.2 & 11.6 & \pm & 0.5 \\
\hline $\mathrm{Na}_{2} \mathrm{O}$ & 6.41 & \pm & 0.06 & 2.5 & \pm & 0.1 & 5.1 & \pm & 0.4 & 6.7 & \pm & 0.4 & 4.9 & \pm & 0.2 & 6.3 & \pm & 0.2 & 4.0 & 4.9 & \pm & 0.2 & 4.9 & \pm & 0.1 \\
\hline $\mathrm{K}_{2} \mathrm{O}$ & 0.086 & \pm & 0.006 & 0.17 & \pm & 0.03 & 0.14 & \pm & 0.03 & 0.5 & \pm & 0.2 & 0.2 & \pm & 0.1 & 0.12 & \pm & 0.02 & 0.43 & 0.28 & \pm & 0.04 & 0.25 & \pm & 0.08 \\
\hline $\mathrm{Cl}$ & & n.a. & & & b.d. & & & b.d. & & 0.022 & \pm & 0.007 & 0.0267 & \pm & 0.0006 & & b.d. & & 0.03 & 0.03 & \pm & 0.01 & 0.03 & \pm & 0.01 \\
\hline $\mathrm{F}$ & & n.a. & & & b.d. & & & b.d. & & & b.d. & 7 & & to 0 . & & 0.07 & \pm & 0.01 & b.d. & & b.d. & & & b.d. & \\
\hline $\begin{array}{l}\mathrm{P}_{2} \mathrm{O}_{5} \\
-(\mathrm{F}, \mathrm{Cl})=\mathrm{O}\end{array}$ & 0.02 & $\begin{array}{l} \pm \\
-\end{array}$ & 0.02 & & b.d. & & & b.d. & & 0.06 & $\begin{array}{c} \pm \\
0.005\end{array}$ & 0.01 & 0.087 & $\begin{array}{c} \pm \\
0.03\end{array}$ & 0.009 & & $\begin{array}{l}\text { 1. to } 0 . \\
0.03\end{array}$ & & $\begin{array}{l}0.04 \\
0.01\end{array}$ & 0.07 & $\begin{array}{c} \pm \\
0.006\end{array}$ & 0.01 & 0.06 & $\begin{array}{c} \pm \\
0.006\end{array}$ & 0.05 \\
\hline Total & 99.3 & \pm & 0.3 & 100 & \pm & 1 & 99 & \pm & 1 & 101 & \pm & 1 & $\begin{array}{c}101 \\
\text { Formulas }\end{array}$ & \pm & 1 & 101.3 & \pm & 0.4 & 100.4 & 100.1 & \pm & 0.5 & 101 & \pm & 1 \\
\hline $\mathrm{Si}$ & 2.585 & \pm & 0.006 & 2.27 & \pm & 0.01 & 2.51 & \pm & 0.04 & 2.57 & \pm & 0.03 & 2.41 & \pm & 0.01 & 2.52 & \pm & 0.01 & 2.4 & 2.47 & \pm & 0.01 & 2.43 & \pm & 0.03 \\
\hline $\mathrm{Al}$ & 1.416 & \pm & 0.006 & 1.65 & \pm & 0.04 & 1.47 & \pm & 0.03 & 1.42 & \pm & 0.03 & 1.57 & \pm & 0.01 & 1.47 & \pm & 0.01 & 1.5 & 1.49 & \pm & 0.01 & 1.53 & \pm & 0.04 \\
\hline $\mathrm{Ti}$ & 0.0009 & \pm & 0.0002 & 0.006 & \pm & 0.002 & 0.003 & \pm & 0.001 & 0.0015 & \pm & 0.0005 & 0.0017 & \pm & 0.0008 & 0.0012 & \pm & 0.0003 & 0.003 & 0.0022 & \pm & 0.0005 & 0.002 & \pm & 0.001 \\
\hline $\mathrm{Fe}$ & 0.0024 & \pm & 0.0006 & 0.08 & \pm & 0.02 & 0.03 & \pm & 0.02 & 0.028 & \pm & 0.008 & 0.026 & \pm & 0.001 & 0.0112 & \pm & 0.0009 & 0.04 & 0.037 & \pm & 0.003 & 0.03 & \pm & 0.01 \\
\hline $\mathrm{Mg}$ & 0.0008 & \pm & 0.0002 & 0.05 & \pm & 0.02 & 0.02 & \pm & 0.01 & 0.004 & \pm & 0.002 & 0.0032 & & 0.0006 & 0.0021 & \pm & 0.0005 & 0.02 & 0.007 & \pm & 0.001 & 0.013 & \pm & 0.007 \\
\hline Mn & 0.0010 & \pm & 0.0003 & 0.0016 & \pm & 0.0005 & 0.003 & \pm & 0.001 & 0.0008 & \pm & 0.0002 & & b.d. & & 0.0006 & \pm & 0.0001 & b.d. & 0.0015 & \pm & 0.0003 & 0.0020 & \pm & 0.0007 \\
\hline $\mathrm{Ca}$ & 0.416 & \pm & 0.006 & 0.74 & \pm & 0.01 & 0.49 & \pm & 0.03 & 0.38 & \pm & 0.03 & 0.56 & \pm & 0.01 & 0.46 & \pm & 0.01 & 0.6 & 0.54 & \pm & 0.01 & 0.56 & \pm & 0.02 \\
\hline $\mathrm{Na}$ & 0.560 & \pm & 0.005 & 0.22 & \pm & 0.01 & 0.45 & \pm & 0.03 & 0.58 & \pm & 0.04 & 0.43 & \pm & 0.02 & 0.54 & \pm & 0.01 & 0.4 & 0.43 & \pm & 0.02 & 0.42 & \pm & 0.01 \\
\hline $\mathrm{K}$ & 0.0049 & \pm & 0.0003 & 0.010 & \pm & 0.002 & 0.008 & \pm & 0.002 & 0.03 & \pm & 0.01 & 0.014 & \pm & 0.004 & 0.0067 & \pm & 0.0009 & 0.02 & 0.016 & \pm & 0.003 & 0.014 & \pm & 0.004 \\
\hline $\mathrm{Cl}$ & 0.0007 & \pm & 0.0006 & & n.a. & & . & n.a. & & 0.002 & \pm & 0.001 & 0.0020 & \pm & 0.0008 & & b.d. & & 0.002 & 0.0022 & \pm & 0.0005 & 0.0020 & \pm & 0.0008 \\
\hline $\mathrm{F}$ & & n.a. & & & n.a. & & & n.a. & & & b.d. & & & to 0 . & & 0.010 & \pm & 0.002 & b.d. & & b.d. & & & b.d. & \\
\hline $\mathrm{P}$ & & n.a. & & & b.d. & & & n.a. & & 0.0023 & \pm & 0.0006 & 0.003 & \pm & 0.001 & 0.0013 & \pm & 0.0002 & 0.002 & 0.0026 & \pm & 0.0006 & 0.002 & \pm & 0.001 \\
\hline $\mathrm{X}_{\mathrm{An}}$ Plag & 0.424 & \pm & 0.007 & 0.76 & \pm & 0.02 & 0.52 & \pm & 0.04 & 0.39 & \pm & 0.04 & 0.557 & \pm & 0.021 & 0.46 & \pm & 0.01 & 0.6 & 0.55 & \pm & 0.01 & 0.56 & \pm & 0.03 \\
\hline $\mathrm{X}_{\mathrm{Ab}}$ plag & 0.571 & \pm & 0.007 & 0.23 & \pm & 0.01 & 0.47 & \pm & 0.04 & 0.59 & \pm & 0.05 & 0.43 & \pm & 0.03 & 0.54 & \pm & 0.02 & 0.4 & 0.44 & \pm & 0.01 & 0.42 & \pm & 0.02 \\
\hline $\mathrm{X}_{\mathrm{Or}}$ plag & 0.0050 & \pm & 0.0003 & 0.010 & \pm & 0.002 & 0.009 & \pm & 0.002 & 0.03 & \pm & 0.01 & 0.014 & \pm & 0.004 & 0.007 & \pm & 0.001 & 0.03 & 0.017 & \pm & 0.003 & 0.014 & \pm & 0.004 \\
\hline
\end{tabular}

n.a. is not available. b.d. is below detection. Uncertainty is the standard deviation of the mean $\left(1 \sigma_{\mathrm{m}}\right)$. 


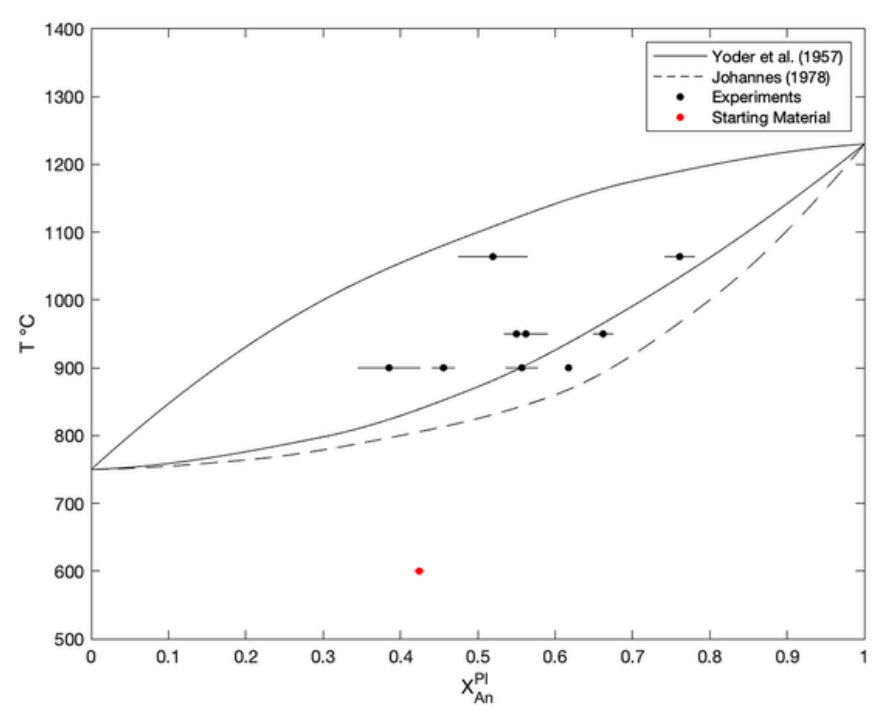

Fig. 7. Phase diagram for starting material and run product plagioclase. $X_{A n}{ }^{p l}$ is the mole fraction of the anorthite component in the plagioclase solid solution. Solid lines are the solidus and liquids determined by Yoder et al. (1957) at $500 \mathrm{MPa}$. Dashed line represents the solidus determined by Johannes (1978) at $500 \mathrm{MPa}$. Uncertainty is the standard deviation of the mean $\left(1 \sigma_{\mathrm{m}}\right)$. Temperature of the starting material is arbitrary.

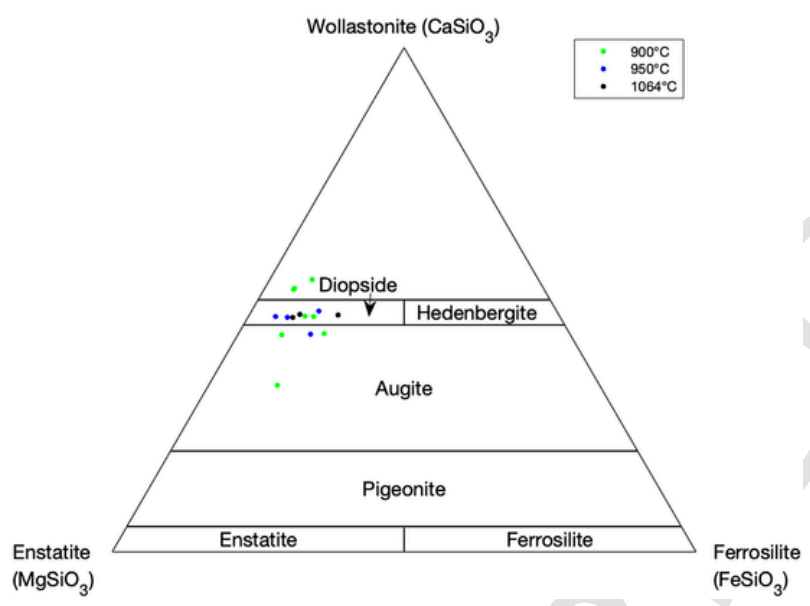

Fig. 8. Ternary diagram of pyroxene compositions.

the concentration of the trace elements increases as the fraction of amphibole and pyroxene decreases (Table 12 and Fig. 9). Notably, the concentration of scandium in the run product glasses is generally below detection (typically between 15 and 30 ppm; see supplementary files). The only run product glasses with scandium consistently above the limit of detection are those glasses from experiment EIP-5. In this experiment the starting material has undergone up to $80 \%$ partial melting and the scandium concentration is approximately equal to that of the bulk starting material (39 ppm). Replicate EIP-9b had a range of scandium concentration from below detection to $16 \mathrm{ppm}$. Clinopyroxene and amphibole are the primary hosts for the trace elements (Sc, Y, V, REEs). Scandium concentrations in run product clinopyroxene and amphibole range from 54 to $120 \mathrm{ppm}$ and 28 to $81 \mathrm{ppm}$, respectively.

Chondrite normalized rare earth element (REE) patterns for the run product glasses, clinopyroxene, and amphibole are presented in Figs. 11 and 12. The REE patterns for both clinopyroxene and amphibole are flat. The REE patterns for run product glasses are generally flat with minor LREE enrichment (Fig. 12). Glasses from experiments with low degrees of partial melting (experiments EIP-4 and EIP-7) have more variable REE patterns. Glasses from experiments with larger degrees of partial melting have less variable and REE patterns similar to the start- ing material, with only minor LREE enrichment. Additionally, there is a lack of a europium anomaly in the run product glasses; although, it may be argued that replicates EIP-4a and EIP-7b may have minor positive europium anomalies (Fig. 12).

\section{Discussion}

\subsection{Melt formation}

The solidus of the Evje-Iveland amphibolite at vapor absent conditions is at or near $900{ }^{\circ} \mathrm{C}$ at a pressure of $500 \mathrm{MPa}$. During partial melting, the first reaction to occur is the breakdown of amphibole (magnesiohornblende) and generation of a sodium-rich, high-aluminum melt at or near amphibole-plagioclase grain boundaries. The initial melt is water undersaturated and any water in the system is transferred directly into the melt. This reaction also produces more-aluminous amphibole (pargasite) and less-sodic plagioclase, as well as an aluminum-rich diopside in the core of the pargasite. One reaction to describe this relationship is: magnesiohornblende + plagioclase

$\rightarrow$ pargasite + less sodic plagioclase

+ aluminian diopside + melt.

This reaction reaches completion at approximately $900{ }^{\circ} \mathrm{C}$. Between 900 and $950^{\circ} \mathrm{C}$ the pargasite and less-sodic plagioclase react to yield additional melt and aluminian diopside:

pargasite + less sodic plagioclase

$\rightarrow$ aluminian diopside + melt.

Above $950{ }^{\circ} \mathrm{C}$, the amphibole and plagioclase are consumed and the reaction products are an aluminian diopside, a melt phase, as well as olivine. These results are in good agreement with previous studies. The solidus as determined from the results of the experiments presented here, as well as the position of the clinopyroxene-in $\left(900{ }^{\circ} \mathrm{C}\right)$ and hornblende-out $\left(950^{\circ} \mathrm{C}\right)$ reactions, are in agreement with results of Wyllie and Wolf (1993) and reference therein. Additionally, crystallization of clinopyroxene within the core of amphibole was also observed by Wolf and Wyllie (1991). The mechanism by which the pyroxene core and amphibole rim forms is, at present, unclear. The increase in the aluminum content of the amphibole and the aluminum-rich pyroxene, are consistent with the results of Rapp et al. (1991), Rushmer (1991), Rapp (1995), and Wolf and Wyllie (1994).

\subsection{Composition of pegmatite-forming melts}

\subsubsection{Major elements}

The composition of the run product glass is the primary interest in this study. A comparison of the experimental glasses in this study to the bulk compositions of the granitic border zones of the Steli pegmatite, the Iveland Wall (a roadcut displaying the relationship of the pegmatites and the host amphibolite) in the Evje-Iveland pegmatite field (Snook, 2014), and two albite zones from the Solås and Topazbrudd pegmatites (Müller et al., 2018) is given in Fig. 3.

Snook (2014) assumed that the border zones of the pegmatites in the Evje-Iveland field are representative of the bulk pegmatite, but this assumption is not without problems. As discussed by London (2008), and noted by Jahns (1982) and Jolliff et al. (1992), the border zones of pegmatites are chilled margins; however, unlike chilled margins in mafic dikes, pegmatite border zones do not efficiently incorporate trace elements and fluxes (i.e. $\mathrm{H}_{2} \mathrm{O}, \mathrm{F}, \mathrm{B}$, and $\mathrm{P}$ ) as they are incompatible in border zone minerals. Pegmatite-forming melts are often enriched in trace elements (e.g. Li, F, Cs etc.) that flux the melt and are incompatible in the minerals in border zones of pegmatites (London, 2008). Thus, as noted by London (2008), the bulk composition of the border zones has a lower concentration of fluxes and incompatible 
Table 5

Major element composition of run product pyroxene.

\begin{tabular}{|c|c|c|c|c|c|c|c|c|c|c|c|c|c|c|c|c|c|c|}
\hline \multirow[t]{2}{*}{ Replicate } & \multicolumn{8}{|l|}{ EIP-4 } & \multicolumn{7}{|l|}{ EIP-5 } & \multicolumn{3}{|c|}{ EIP-7 } \\
\hline & a & & & a & $\mathrm{b}$ & & & $\mathrm{b}$ & a & & & a & $\mathrm{b}$ & & & a & & \\
\hline $\mathrm{N}$ & 15 & & & 1 & 13 & & & 1 & 10 & & & 1 & 11 & & & 8 & & \\
\hline $\mathrm{SiO}_{2}$ & 43.5 & \pm & 0.3 & 49 & 44.8 & \pm & 0.4 & 45.9 & 47.9 & \pm & 0.7 & 47.9 & 48.5 & \pm & 0.3 & 51.9 & \pm & 0.3 \\
\hline $\mathrm{Al}_{2} \mathrm{O}_{3}$ & 12.8 & \pm & 0.3 & 6.4 & 11.5 & \pm & 0.6 & 4.7 & 5.2 & \pm & 0.3 & 10.1 & 4.8 & \pm & 0.2 & 2.9 & \pm & 0.2 \\
\hline $\mathrm{TiO}_{2}$ & 2.18 & \pm & 0.07 & 1.2 & 1.62 & \pm & 0.09 & 0.72 & 0.83 & \pm & 0.04 & 1.2 & 0.61 & \pm & 0.03 & 0.5 & \pm & 0.05 \\
\hline $\mathrm{FeO}$ & 3.8 & \pm & 0.4 & 3 & 2.7 & \pm & 0.3 & 8.5 & 4.2 & \pm & 0.6 & 7.9 & 4.8 & \pm & 0.3 & 6.4 & \pm & 0.1 \\
\hline $\mathrm{Fe}_{2} \mathrm{O}_{3}$ & 3.8 & \pm & 0.5 & 3.2 & 3.8 & \pm & 0.4 & b.d. & 7 & \pm & 1 & 0.91 & 6.4 & \pm & 0.3 & 4 & \pm & 0.1 \\
\hline $\mathrm{MnO}$ & 0.12 & \pm & 0.01 & 0.13 & 0.134 & \pm & 0.007 & 0.19 & 0.23 & \pm & 0.02 & 0.16 & 0.22 & \pm & 0.01 & 0.42 & \pm & 0.02 \\
\hline $\mathrm{CaO}$ & 22.0 & \pm & 0.4 & 24.1 & 21.6 & \pm & 0.7 & 18.8 & 20.1 & \pm & 0.8 & 19.1 & 20.4 & \pm & 0.3 & 20.8 & \pm & 0.1 \\
\hline $\mathrm{Na}_{2} \mathrm{O}$ & 0.7 & \pm & 0.1 & 0.39 & 0.7 & \pm & 0.1 & 0.26 & 0.36 & \pm & 0.02 & 1.2 & 0.31 & \pm & 0.01 & 1.4 & \pm & 0.1 \\
\hline $\mathrm{K}_{2} \mathrm{O}$ & 0.08 & \pm & 0.03 & b.d. & 0.14 & \pm & 0.04 & 0.04 & 0.018 & \pm & 0.004 & 0.25 & 0.028 & \pm & 0.005 & 0.03 & \pm & 0.01 \\
\hline $\mathrm{Cl}$ & 0.014 & \pm & 0.001 & b.d. & 0.019 & \pm & 0.003 & b.d. & 0.017 & \pm & 0.002 & 0.04 & 0.012 & \pm & 0.001 & 0.018 & \pm & 0.005 \\
\hline $\mathrm{F}$ & 0.14 & \pm & 0.02 & b.d. & 0.3 & \pm & 0.04 & b.d. & 0.14 & \pm & 0.02 & b.d. & 0.28 & \pm & 0.03 & 0.07 & \pm & 0.01 \\
\hline $\mathrm{P}_{2} \mathrm{O}_{5}$ & 0.051 & \pm & 0.002 & 0.08 & 0.056 & \pm & 0.008 & b.d. & 0.11 & \pm & 0.01 & b.d. & 0.044 & \pm & 0.008 & 0.07 & \pm & 0.01 \\
\hline$-(\mathrm{F}, \mathrm{Cl})=\mathrm{O}$ & & 0.06 & & - & & 0.13 & & & & 0.06 & & 0.01 & & 0.12 & & & 0.03 & \\
\hline Total & 100.4 & \pm & 0.9 & 101.8 & 100 & \pm & 1 & 101.7 & 100 & \pm & 2 & 99.8 & 100.1 & \pm & 0.7 & 102 & \pm & 0.4 \\
\hline \multicolumn{19}{|c|}{ Formulas } \\
\hline $\mathrm{Ti}$ & 0.061 & \pm & 0.002 & 0.03 & 0.045 & \pm & 0.003 & 0.02 & 0.023 & \pm & 0.001 & 0.03 & 0.017 & \pm & 0.001 & 0.014 & \pm & 0.001 \\
\hline $\mathrm{Fe}$ & 0.12 & \pm & 0.01 & 0.09 & 0.083 & \pm & 0.008 & 0.26 & 0.13 & \pm & 0.02 & 0.24 & 0.15 & \pm & 0.01 & 0.195 & \pm & 0.004 \\
\hline $\mathrm{Fe}^{3+}$ & 0.1 & \pm & 0.01 & 0.09 & 0.105 & \pm & 0.009 & - & 0.19 & \pm & 0.03 & 0.03 & 0.179 & \pm & 0.006 & 0.11 & \pm & 0.004 \\
\hline $\mathrm{Mg}$ & 0.63 & \pm & 0.01 & 0.77 & 0.7 & \pm & 0.01 & 1.2 & 0.79 & \pm & 0.04 & 0.61 & 0.77 & \pm & 0.02 & 0.736 & \pm & 0.006 \\
\hline $\mathrm{Mn}$ & 0.0037 & \pm & 0.0003 & 0 & 0.0042 & \pm & 0.0002 & 0.006 & 0.0072 & \pm & 0.0004 & 0.005 & 0.0069 & \pm & 0.0002 & 0.013 & \pm & 0.0006 \\
\hline $\mathrm{Ca}$ & 0.87 & \pm & 0.02 & 0.94 & 0.86 & \pm & 0.03 & 0.74 & 0.8 & \pm & 0.04 & 0.76 & 0.82 & \pm & 0.01 & 0.814 & \pm & 0.005 \\
\hline $\mathrm{Na}$ & 0.05 & \pm & 0.008 & 0.03 & 0.051 & \pm & 0.009 & 0.02 & 0.026 & \pm & 0.001 & 0.09 & 0.0226 & \pm & 0.0007 & 0.1 & \pm & 0.008 \\
\hline $\mathrm{K}$ & 0.004 & \pm & 0.002 & b.d. & 0.006 & \pm & 0.002 & 0.002 & 0.0009 & \pm & 0.0002 & 0.01 & 0.0014 & \pm & 0.0002 & 0.0013 & \pm & 0.0004 \\
\hline $\mathrm{Cl}$ & 0.0009 & \pm & 0.0001 & b.d. & 0.0012 & \pm & 0.0002 & b.d. & 0.0011 & \pm & 0.0001 & 0.003 & 0.0007 & \pm & 0.0001 & 0.0011 & \pm & 0.0003 \\
\hline $\mathrm{F}$ & 0.01604 & \pm & 0.00001 & b.d. & 0.035 & \pm & 0.003 & b.d. & 0.017 & \pm & 0.004 & b.d. & 0.033 & \pm & 0.002 & 0.008 & \pm & 0.002 \\
\hline $\mathrm{P}$ & 0.0016 & \pm & 0.00008 & 0.003 & 0.0018 & \pm & 0.0003 & b.d. & 0.0033 & \pm & 0.0003 & b.d. & 0.0014 & \pm & 0.0003 & 0.002 & \pm & 0.0004 \\
\hline $\mathrm{X}_{\mathrm{Wo}}{ }^{\mathrm{Pyx}}$ & 0.54 & \pm & 0.01 & 0.52 & 0.52 & \pm & 0.02 & 0.33 & 0.47 & \pm & 0.03 & 0.47 & 0.471 & \pm & 0.009 & 0.467 & \pm & 0.004 \\
\hline $\mathrm{X}_{\mathrm{En}}{ }^{\mathrm{Pyx}}$ & 0.39 & \pm & 0.01 & 0.43 & 0.43 & \pm & 0.01 & 0.55 & 0.46 & \pm & 0.03 & 0.38 & 0.44 & \pm & 0.01 & 0.422 & \pm & 0.004 \\
\hline $\mathrm{X}_{\mathrm{Fs}}{ }^{\mathrm{Pyx}}$ & 0.072 & \pm & 0.008 & 0.05 & 0.051 & \pm & 0.005 & 0.12 & 0.08 & \pm & 0.01 & 0.15 & 0.086 & \pm & 0.008 & 0.112 & \pm & 0.002 \\
\hline $\mathrm{Q}$ & 1.62 & \pm & 0.03 & 1.8 & 1.64 & \pm & 0.03 & 2.2 & 1.73 & \pm & 0.06 & 1.6 & 1.74 & \pm & 0.02 & 1.744 & \pm & 0.009 \\
\hline $\mathrm{J}$ & 0.1 & \pm & 0.02 & 0.05 & 0.1 & \pm & 0.02 & 0.04 & 0.052 & \pm & 0.003 & 0.18 & 0.045 & \pm & 0.001 & 0.2 & \pm & 0.02 \\
\hline
\end{tabular}




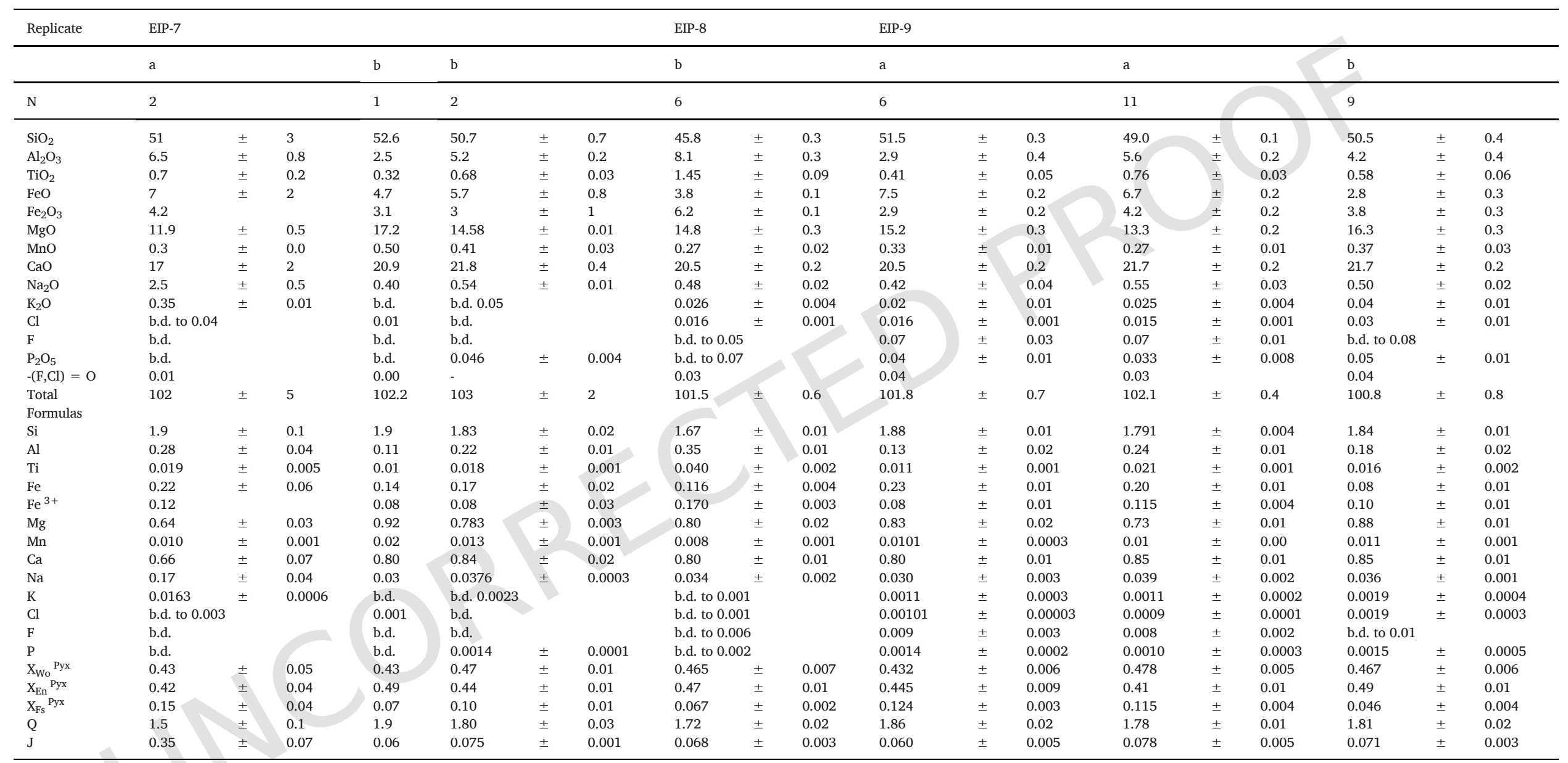

$\mathrm{Fe}_{2} \mathrm{O}_{3}$ calculated after the method of Droop (1987). Q $=\mathrm{Fe}+\mathrm{Mg}+$ Ca. $\mathrm{J}=2 \mathrm{Na}$. n.a. is not available. b.d. is below detection. Uncertainty is the standard deviation of the mean (1 $\sigma_{\mathrm{m}}$ ). 
Table 6

Major element composition of run product olivine.

Expand

\begin{tabular}{|c|c|c|c|c|c|c|c|c|c|c|c|c|c|}
\hline \multirow[t]{2}{*}{ Replicate } & \multicolumn{7}{|l|}{ EIP-4 } & \multicolumn{6}{|l|}{ EIP-5 } \\
\hline & $\mathrm{a}$ & & & $\mathrm{a}$ & & & $\mathrm{b}$ & $\mathrm{a}$ & & & $\mathrm{b}$ & & \\
\hline $\mathrm{N}$ & 6 & & & 2 & & & 1 & 12 & & & 12 & & \\
\hline $\mathrm{SiO}_{2}$ & 39.11 & \pm & 0.04 & 37.1 & \pm & 0.9 & 38.6 & 37.39 & \pm & 0.08 & 36.6 & \pm & 0.2 \\
\hline $\mathrm{Al}_{2} \mathrm{O}_{3}$ & 0.084 & \pm & 0.008 & 1 & \pm & 1 & 0.41 & 0.24 & \pm & 0.08 & 0.20 & \pm & 0.08 \\
\hline $\mathrm{TiO}_{2}$ & 0.06 & \pm & 0.01 & \multicolumn{3}{|c|}{ b.d. to 0.007} & 0.06 & 0.06 & \pm & 0.01 & 0.07 & \pm & 0.01 \\
\hline $\mathrm{FeO}$ & 18.9 & \pm & 0.3 & 27.8 & \pm & 0.3 & 23.1 & 28.76 & \pm & 0.42 & 31.7 & \pm & 0.3 \\
\hline $\mathrm{Fe}_{2} \mathrm{O}_{3}$ & 1.4 & \pm & 0.1 & \multicolumn{3}{|c|}{ b.d. to 1.27} & - & & - & & 0.2 & \pm & 0.3 \\
\hline $\mathrm{MgO}$ & 41.5 & \pm & 0.2 & 32.3 & \pm & 0.6 & 37.7 & 33.1 & \pm & 0.2 & 30.4 & \pm & 0.4 \\
\hline $\mathrm{MnO}$ & 0.33 & \pm & 0.01 & 0.738 & \pm & 0.001 & 0.69 & 0.44 & \pm & 0.02 & 0.47 & \pm & 0.01 \\
\hline $\mathrm{CaO}$ & 0.445 & \pm & 0.002 & 0.331 & \pm & 0.001 & 0.56 & 0.43 & \pm & 0.04 & 0.5 & \pm & 0.2 \\
\hline $\mathrm{Na}_{2} \mathrm{O}$ & 0.004 & \pm & 0.001 & 0.2 & \pm & 0.2 & 0.1 & 0.07 & \pm & 0.02 & 0.04 & \pm & 0.01 \\
\hline $\mathrm{K}_{2} \mathrm{O}$ & 0.0107 & \pm & 0.0006 & 0.07 & \pm & 0.06 & 0.02 & 0.024 & \pm & 0.005 & 0.020 & \pm & 0.002 \\
\hline $\mathrm{Cl}$ & 0.019 & \pm & 0.001 & 0.022 & \pm & 0.005 & b.d. & 0.016 & \pm & 0.002 & 0.019 & \pm & 0.003 \\
\hline $\mathrm{F}$ & 0.050 & \pm & 0.008 & & & & b.d. & \multicolumn{3}{|c|}{ b.d. } & \multicolumn{3}{|c|}{ b.d. } \\
\hline $\mathrm{P}_{2} \mathrm{O}_{5}$ & \multicolumn{3}{|c|}{ b.d. to 0.04} & \multicolumn{3}{|c|}{ b.d. } & b.d. & 0.12 & \pm & 0.01 & & & \\
\hline$-(\mathrm{F}, \mathrm{Cl})=\mathrm{O}$ & \multicolumn{3}{|c|}{0.03} & \multicolumn{3}{|c|}{-} & - & & 0.00 & & & 0.004 & \\
\hline $\begin{array}{l}\text { Total } \\
\text { Formulas }\end{array}$ & 101.9 & \pm & 0.4 & 100 & \pm & 2 & 101.2 & 100.6 & \pm & 0.5 & 100.4 & \pm & 0.7 \\
\hline $\mathrm{Si}$ & 0.987 & \pm & 0.001 & 1.00 & \pm & 0.01 & 1.00 & 0.998 & \pm & 0.002 & 1.00 & \pm & 0.01 \\
\hline $\mathrm{Al}$ & 0.0025 & \pm & 0.0002 & 0.04 & \pm & 0.03 & 0.01 & 0.007 & \pm & 0.003 & 0.007 & \pm & 0.002 \\
\hline $\mathrm{Ti}$ & 0.0011 & \pm & 0.0002 & \multicolumn{3}{|c|}{ b.d. 0.00014} & 0.001 & 0.0011 & \pm & 0.0002 & 0.0014 & \pm & 0.0002 \\
\hline $\mathrm{Fe}$ & 0.398 & \pm & 0.006 & 0.62 & \pm & 0.01 & 0.50 & 0.642 & \pm & 0.009 & 0.721 & \pm & 0.009 \\
\hline $\mathrm{Fe}^{3+}$ & 0.026 & $\begin{array}{l}- \\
\pm\end{array}$ & 0.002 & \multicolumn{3}{|c|}{ b.d. to 0.026} & - & & - & & 0.005 & \pm & 0.007 \\
\hline $\mathrm{Mg}$ & 1.561 & \pm & 0.006 & 1.29 & \pm & 0.04 & 1.45 & 1.318 & \pm & 0.005 & 1.24 & \pm & 0.02 \\
\hline Mn & 0.0071 & \pm & 0.0002 & 0.0168 & \pm & 0.0002 & 0.02 & 0.0099 & \pm & 0.0004 & 0.0108 & \pm & 0.0003 \\
\hline $\mathrm{Ca}$ & 0.01203 & \pm & 0.00004 & 0.0095 & \pm & 0.0001 & 0.02 & 0.012 & \pm & 0.001 & 0.016 & \pm & 0.005 \\
\hline $\mathrm{Na}$ & 0.00018 & \pm & 0.00004 & 0.01 & \pm & 0.01 & 0.00 & 0.003 & \pm & 0.001 & 0.002 & \pm & 0.001 \\
\hline $\mathrm{K}$ & 0.00034 & \pm & 0.00002 & 0.002 & \pm & 0.002 & 0.00 & 0.0008 & \pm & 0.0001 & 0.0007 & \pm & 0.0001 \\
\hline $\mathrm{Cl}$ & 0.0008 & \pm & 0.0001 & 0.0010 & \pm & 0.0002 & b.d. & \multirow{3}{*}{\multicolumn{3}{|c|}{$\begin{array}{l}\text { b.d. } 0.0007 \\
\text { b.d. } \\
\text { b.d. to } 0.003\end{array}$}} & 0.00088 & \pm & 0.00002 \\
\hline $\mathrm{F}$ & \multicolumn{3}{|c|}{ b.d. to 0.004} & \multirow{2}{*}{\multicolumn{3}{|c|}{$\begin{array}{l}\text { b.d. } \\
\text { b.d. }\end{array}$}} & b.d. & & & & & b.d. & \\
\hline $\mathrm{P}$ & 0.0009 & \pm & 0.0002 & & & & b.d. & & & & & b.d. & \\
\hline $\mathrm{X}_{\mathrm{Fo}} \mathrm{Ol}$ & 0.80 & \pm & 0.01 & 0.67 & \pm & 0.02 & 0.74 & 0.67 & \pm & 0.01 & 0.63 & \pm & 0.01 \\
\hline $\mathrm{X}_{\mathrm{Fa}}$ Ol & 0.203 & \pm & 0.003 & 0.33 & \pm & 0.01 & 0.26 & 0.328 & \pm & 0.005 & 0.369 & \pm & 0.006 \\
\hline
\end{tabular}

$\mathrm{Fe}^{3+}$ calculated after the method of Droop (1987). b.d. is below detection. Uncertainty is the standard deviation of the mean (1 $\left.\sigma_{\mathrm{m}}\right)$.

trace elements than the initial melt. Müller et al. (2018) used modal analyses of the pegmatites and image analysis to determine the bulk composition of the coarse-grained albite zones by modal recombination, which may represent some portion of the initial pegmatite-forming melt. However, determination of the initial melt compositions by other means, has not been described for bulk compositions of the Evje-Iveland pegmatites. Determining the bulk composition of the pegmatite by modal recombination as done by Müller et al. (2018) would provide an additional estimate of the bulk composition that may be able to account for lower concentration of fluxes or incompatible trace elements as noted by London (2008). Such modal recombination attempts have been successful in previous studies such as for the Tanco pegmatite in Manitoba, Canada (Stilling et al., 2006). Because this type of modal recombination has not been completed for the bulk composition of the Evje-Iveland pegmatites, the composition of the border zones as determined by Snook (2014) is thought to be the best estimate. However, the modal recombination of the albite zones from Müller et al. (2018) will also be considered.

The compositions of experimental glasses are compared to pegmatites in Fig. 3 and they are less siliceous than the Steli and the Iveland Wall pegmatites; however, the experimental glasses have approximately the same $\mathrm{SiO}_{2}$ concentrations as the albite zones. Only one ex- periment (EIP-8b) has an $\mathrm{SiO}_{2}$ concentration greater than $70 \mathrm{wt} \%$ and experiment EIP-7b has approximately the same $\mathrm{SiO}_{2}$ concentration as the fine-grained granitic facies in the upper contact (border zone) of the Steli pegmatite (FG-UC). The glasses in the remainder of the experiments have $\mathrm{SiO}_{2}$ concentrations more than $5 \mathrm{wt} \%$ lower than the Steli and the Iveland Wall pegmatites. The glass from experiments performed at temperatures above $950{ }^{\circ} \mathrm{C}$ generally have $\mathrm{Al}_{2} \mathrm{O}_{3}$ concentrations comparable to the Steli and the Iveland Wall pegmatites, whereas the experiments performed at $900{ }^{\circ} \mathrm{C}$ are more aluminous. The same is observed for $\mathrm{Na}_{2} \mathrm{O}$. The elevated $\mathrm{Na}_{2} \mathrm{O}$ concentrations are particularly notable in the $900{ }^{\circ} \mathrm{C}$ experiments. Müller et al. (2018) suggested that melt-melt immiscibility resulted in the generation of an alkali-water-poor melt and an alkali (sodium-dominated)-water-fluorine-rich melt and the formation ofalbite zones. The low-degree partial melts in the $900{ }^{\circ} \mathrm{C}$ experiments are aluminous and sodium-rich and are compositionally similar to the albite zones. However, they are fluorine-poor and water-undersaturated and are thus unlikely to be directly responsible for the generation of the albite zones. Instead, as suggested by Müller et al. (2018), melt-melt immiscibility was likely to occur at late stages of pegmatite formation as a result of magmatic differentiation. The remaining major elements in experiments performed at 900 and $950{ }^{\circ} \mathrm{C}$ are comparable to the Steli and Iveland Wall pegmatites 
Table 7

Major element composition and formulas of run product biotite.

Expand

\begin{tabular}{|c|c|c|c|c|}
\hline Replicate & \multicolumn{4}{|l|}{ EIP-4 } \\
\hline & \multicolumn{3}{|l|}{$\mathrm{a}$} & $\mathrm{b}$ \\
\hline $\mathrm{N}$ & & 2 & & 1 \\
\hline $\mathrm{SiO}_{2}$ & 38.4 & \pm & 0.3 & 37.7 \\
\hline $\mathrm{Al}_{2} \mathrm{O}_{3}$ & 17.0 & \pm & 0.3 & 17.4 \\
\hline $\mathrm{TiO}_{2}$ & 0.18 & \pm & 0.05 & 0.3 \\
\hline $\mathrm{FeO}$ & 10.64 & \pm & 0.08 & 9.2 \\
\hline $\mathrm{MgO}$ & 21.1 & \pm & 0.6 & 21.7 \\
\hline $\mathrm{MnO}$ & 0.10 & \pm & 0.01 & 0.07 \\
\hline $\mathrm{CaO}$ & 0.10 & \pm & 0.03 & 0.07 \\
\hline $\mathrm{Na}_{2} \mathrm{O}$ & 2.38 & \pm & 0.04 & 2.3 \\
\hline $\mathrm{K}_{2} \mathrm{O}$ & 6.8 & \pm & 0.2 & 7.1 \\
\hline $\mathrm{Cl}$ & 0.09 & \pm & 0.01 & 0.09 \\
\hline $\mathrm{F}$ & & b.d. & & b.d. \\
\hline $\mathrm{P}_{2} \mathrm{O}_{5}$ & & b.d. & & b.d. \\
\hline$-(\mathrm{F}, \mathrm{Cl})=\mathrm{O}$ & & 0.02 & & 0.02 \\
\hline Total & 96.8 & \pm & 0.7 & 95.8 \\
\hline $\mathrm{H}_{2} \mathrm{O}$ & 4.21 & \pm & 0.03 & 4.2 \\
\hline \multicolumn{5}{|c|}{ Formulas } \\
\hline \multicolumn{5}{|c|}{ Tetrahedral cations } \\
\hline $\mathrm{Si}$ & 2.711 & \pm & 0.001 & 2.7 \\
\hline $\mathrm{Al}$ & 1.289 & \pm & 0.001 & 1.3 \\
\hline Total & 4.000 & \pm & 0.002 & 4.00 \\
\hline \multicolumn{5}{|c|}{ Octahedral cations } \\
\hline $\mathrm{Al}$ & 0.13 & \pm & 0.03 & 0.12 \\
\hline $\mathrm{Ti}$ & 0.010 & \pm & 0.003 & 0.02 \\
\hline $\mathrm{Fe}^{3+}$ & 0.20 & \pm & 0.02 & 0.24 \\
\hline $\mathrm{Fe}^{2+}$ & 0.43 & \pm & 0.03 & 0.30 \\
\hline $\mathrm{Mg}$ & 2.22 & \pm & 0.05 & 2.3 \\
\hline Mn & 0.006 & \pm & 0.001 & 0.00 \\
\hline Total & 2.99 & \pm & 0.07 & 3.0 \\
\hline \multicolumn{5}{|c|}{ A site cations } \\
\hline $\mathrm{K}$ & 0.62 & \pm & 0.01 & 0.64 \\
\hline $\mathrm{Ca}$ & 0.007 & \pm & 0.002 & 0.01 \\
\hline $\mathrm{Na}$ & 0.326 & \pm & 0.003 & 0.31 \\
\hline Total & 0.95 & \pm & 0.01 & 0.96 \\
\hline \multicolumn{5}{|c|}{ Hydroxyl site cations } \\
\hline $\mathrm{Cl}$ & 0.011 & \pm & 0.002 & 0.01 \\
\hline $\mathrm{OH}$ & 1.989 & \pm & 0.002 & 2.0 \\
\hline $\mathrm{F}$ & & b.d & & b.d \\
\hline $\mathrm{X}_{\mathrm{Ann}}{ }^{\mathrm{Bt}}$ & 0.14 & \pm & 0.01 & 0.1 \\
\hline $\mathrm{X}_{\mathrm{Fe}^{3+}}{ }^{\mathrm{Bt}}$ & 0.07 & \pm & 0.02 & 0.08 \\
\hline $\mathrm{X}_{\mathrm{Phl}}{ }^{\mathrm{Bt}}$ & 0.741 & \pm & 0.005 & 0.77 \\
\hline
\end{tabular}

Formulas calculated after the method of Dymek (1983). b.d. is below detection. Uncertainty is the standard deviation of the mean $\left(1 \sigma_{\mathrm{m}}\right)$.

and are greater than the albite zones. The Steli and the Iveland Wall pegmatites have approximately the same bulk composition, but are more siliceous, aluminous, and sodic than the albite zones. Based on the bulk composition, it is not unreasonable to conclude that partial melting of $<40 \%$ by mass of an amphibolite host rock may produce pegmatite-forming (i.e. granitic) melts. This degree of partial melting is consistent with the conclusions of Rapp et al. (1991) and Rapp and Watson (1995), which suggest $10 \%$ to $40 \%$ and 10 to $55 \%$ of partial melting to produce granitic melts, respectively.

\subsubsection{Trace elements}

There are also differences in the trace element signatures among the experimental glasses and the Evje-Iveland pegmatites. The experimental glasses in this study are strongly depleted in scandium and many of the REEs are below detection in low-degree partial melts (Table 12). At the temperatures that anatexis occurs $\left(>700{ }^{\circ} \mathrm{C}\right)$, London $(2005$, 2018) and Černý et al. (2005) note that the concentrations of essential constituents (e.g. Nb, Ta, Be, etc.) in a melt needed to saturate that melt with minerals (e.g. columbite, beryl, etc.) often found in pegmatites are significantly higher than the protolith. As such, large degrees of differentiation are needed to reach the saturation point for these minerals. Thus, it is unlikely that the low-degree partial melts generated in the experiments discussed here, or in natural settings, have high enough concentrations to be saturated with minerals such as thortveitite, the columbite-group minerals, or beryl. It should be noted that at very low melt fractions, for elements with partition coefficients $<<1$, there could be a large enrichment of that element in the melt; however, there are no indications that this is the case in the experiments discussed in this study.

Rubidium/strontium ratios are commonly used to gauge the degree of differentiation (fractional crystallization and/or partial melting) that a magmatic system has undergone (Arth and Hanson, 1975; Cerny et al., 1985; Clark and Černý, 1987; Frost et al., 2016; Halliday et al., 1991; Walker et al., 1989). Because strontium is compatible and rubidium is incompatible in feldspars, as magmatic systems evolve the $\mathrm{Rb} / \mathrm{Sr}$ ratio of the melt tends to increase particularly in highly evolved granitic and pegmatitic systems (e.g. Cerny et al., 1985; Clark and Černý, 1987; Frost et al., 2016; Halliday et al., 1991). Thus, a comparison of $\mathrm{Rb} / \mathrm{Sr}$ ratio of Evje-Iveland pegmatites and the experimental glasses may elucidate whether magmatic differentiation (likely fractional crystallization; see Halliday et al., 1991) has occurred. The $\mathrm{Rb} / \mathrm{Sr}$ of the Evje-Iveland pegmatites is variable and ranges from 0.1 to 60 and the $\mathrm{Rb} / \mathrm{Sr}$ of the experiments performed in this work ranges from 0.01 to 0.3 (Fig. 13). Given that the experiments represent between 10 and $90 \%$ partial melting of the host amphibolite, the range of rubidium and strontium concentrations and $\mathrm{Rb} / \mathrm{Sr}$ ratios of the experiments are those that are possible by partial melting of the amphibole only. In order to produce the high rubidium concentrations, and thus higher $\mathrm{Rb} / \mathrm{Sr}$ ratios seen in the Evje-Iveland pegmatites, some degree of fractional crystallization is needed. The Iveland Wall and Kåbuland pegmatites are the exception to this as they have similar $\mathrm{Rb} / \mathrm{Sr}$ to the experiments. Additionally, although the Høvringsvatnet granites have similar rubidium concentrations to the Evje-Iveland pegmatites, they have significantly higher strontium concentrations (Fig. 13). If the Høvringsvatnet granites were the source of the pegmatite-forming melt, as suggested by previous studies, some degree of differentiation would be required to remove strontium from a melt. This may be the case if the pegmatite-forming melt were the residual melt in the system that crystallized and formed the Høvringsvatnet granites.

The REE patterns of the run product glasses are compared to the REE patterns of the border and wall zones of pegmatites found in the Evje-Iveland pegmatite field and the Høvringsvatnet granites in Fig. 12. The first clear difference is that the pegmatites have significant negative europium anomalies that are not present in the REE patterns of the run product glasses. The exception to this is the bulk Iveland Wall sample (Snook, 2014), which has a positive europium anomaly and roughly similar chondrite normalized REE values to the low-degree partial melts (experiments EIP-4 and EIP-7). Snook (2014) noted that LREE or HREE enrichment relative to each REE group in the pegmatites is minimal, but variable. Although the experimental glasses in this study are not LREE or HREE enriched, the pegmatites have greater chondrite normalized REE values than the run product glasses. The REE patterns for the Høvringsvatnet granites, the source of the pegmatitic melts proposed by some, are LREE enriched and HREE depleted with no europium anomaly, which are significantly different from the pegmatites and experimental glasses.

In order to further examine the hypothesis that the petrogenesis of the pegmatites involved anatexis, it is useful to compare the experi- 
Table 8

Major element composition and formulas of starting and run product oxides.

Expand

\begin{tabular}{|c|c|c|c|c|c|c|c|c|c|c|c|c|}
\hline \multirow[t]{2}{*}{ Replicate } & \multicolumn{3}{|c|}{ 23051707b (Ilmenite) } & \multicolumn{6}{|l|}{ EIP-7 } & \multicolumn{3}{|l|}{ EIP-8 } \\
\hline & \multicolumn{3}{|l|}{ - } & \multicolumn{3}{|l|}{$\mathrm{a}$} & \multicolumn{6}{|c|}{$\mathrm{b}$} \\
\hline $\mathrm{N}$ & \multicolumn{3}{|l|}{1} & \multicolumn{3}{|l|}{6} & \multicolumn{3}{|c|}{3} & \multicolumn{3}{|l|}{5} \\
\hline $\mathrm{SiO}_{2}$ & & 0.03 & & 0.9 & \pm & 0.2 & 0.4 & \pm & 0.3 & 0.4 & \pm & 0.1 \\
\hline $\mathrm{Al}_{2} \mathrm{O}_{3}$ & & 0.01 & & 3.4 & \pm & 0.4 & 1.1 & \pm & 0.1 & 6 & \pm & 1 \\
\hline $\mathrm{TiO}_{2}$ & & 50.8 & & 4.5 & \pm & 0.2 & 22 & \pm & 2 & 2.1 & \pm & 0.3 \\
\hline $\mathrm{FeO}$ & & 43.8 & & 29.9 & \pm & 0.4 & 45 & \pm & 2 & 27.2 & \pm & 0.9 \\
\hline $\mathrm{Fe}_{2} \mathrm{O}_{3}$ & & - & & 54.6 & \pm & 0.5 & 24 & \pm & 4 & 57 & \pm & 1 \\
\hline $\mathrm{MgO}$ & & 0.04 & & 2.5 & \pm & 0.1 & 2.7 & \pm & 0.4 & 3.0 & \pm & 0.9 \\
\hline $\mathrm{MnO}$ & & 2.6 & & 0.46 & \pm & 0.01 & 0.23 & \pm & 0.05 & 0.9 & \pm & 0.1 \\
\hline $\mathrm{CaO}$ & & 0.17 & & 0.38 & \pm & 0.04 & 0.4 & \pm & 0.2 & 0.26 & \pm & 0.01 \\
\hline $\mathrm{Na}_{2} \mathrm{O}$ & & b.d. & & 0.22 & \pm & 0.06 & 0.04 & \pm & 0.02 & 0.042 & \pm & 0.009 \\
\hline $\mathrm{K}_{2} \mathrm{O}$ & & b.d. & & 0.05 & \pm & 0.01 & 0.04 & \pm & 0.01 & 0.040 & \pm & 0.009 \\
\hline $\mathrm{Cl}$ & & n.a. & & 0.04 & \pm & 0.01 & \multirow{4}{*}{\multicolumn{3}{|c|}{$\begin{array}{l}\text { b.d. to } 0.0 \\
\text { b.d. } \\
\text { b.d. } \\
0.01\end{array}$}} & 0.020 & \pm & 0.005 \\
\hline $\mathrm{F}$ & & n.a. & & & b.d. & & & & & \multicolumn{3}{|c|}{ b.d. } \\
\hline $\mathrm{P}_{2} \mathrm{O}_{5}$ & & b.d. & & & b.d. & & & & & \multicolumn{3}{|c|}{ b.d. to 0.03} \\
\hline$-(\mathrm{F}, \mathrm{Cl})=\mathrm{O}$ & & - & & & 0.01 & & & & & \multicolumn{3}{|c|}{0.005} \\
\hline Total & 97 & \pm & 1 & 97 & \pm & $\begin{array}{c}1 \\
\text { Formula }\end{array}$ & 95 & \pm & 5 & 97 & \pm & 2 \\
\hline $\mathrm{Si}$ & & 0.001 & & 0.03 & \pm & 0.01 & 0.01 & \pm & 0.01 & 0.01 & \pm & 0.00 \\
\hline $\mathrm{Al}$ & & 0.0002 & & 0.15 & \pm & 0.02 & 0.048 & \pm & 0.005 & 0.25 & \pm & 0.04 \\
\hline $\mathrm{Ti}$ & & 0.991 & & 0.128 & \pm & 0.005 & 0.63 & \pm & 0.07 & 0.06 & \pm & 0.01 \\
\hline $\mathrm{Fe}$ & & 0.95 & & 0.94 & \pm & 0.02 & 1.44 & \pm & 0.04 & 0.85 & \pm & 0.04 \\
\hline $\mathrm{Fe}^{3+}$ & & - & & 1.55 & \pm & 0.02 & 0.68 & \pm & 0.11 & 1.61 & \pm & 0.05 \\
\hline $\mathrm{Mg}$ & & 0.00 & & 0.14 & \pm & 0.01 & 0.16 & \pm & 0.02 & 0.17 & \pm & 0.05 \\
\hline $\mathrm{Mn}$ & & 0.06 & & 0.0146 & \pm & 0.0003 & 0.007 & \pm & 0.001 & 0.029 & \pm & 0.004 \\
\hline $\mathrm{Ca}$ & & 0.0047 & & 0.015 & \pm & 0.002 & 0.01 & \pm & 0.01 & 0.010 & \pm & 0.001 \\
\hline $\mathrm{Na}$ & & b.d. & & 0.016 & \pm & 0.005 & 0.003 & \pm & 0.002 & 0.0031 & \pm & 0.0007 \\
\hline $\mathrm{K}$ & & b.d. & & 0.002 & \pm & 0.001 & 0.0019 & \pm & 0.0001 & 0.0019 & \pm & 0.0003 \\
\hline $\mathrm{Cl}$ & & n.a. & & 0.002 & \pm & 0.001 & \multicolumn{3}{|c|}{ b.d. to 0.002} & 0.0013 & \pm & 0.0003 \\
\hline $\mathrm{F}$ & & n.a. & & & b.d. & & \multicolumn{3}{|c|}{ b.d. } & \multicolumn{3}{|c|}{ b.d. } \\
\hline $\mathrm{P}$ & & b.d. & & & b.d. & & & b.d. & & \multicolumn{3}{|c|}{ b.d. to 0.001} \\
\hline $\mathrm{X}_{\mathrm{Mag}} \mathrm{Sp}$ & & & & 0.66 & \pm & 0.02 & 0.19 & \pm & 0.07 & 0.68 & \pm & 0.06 \\
\hline $\mathrm{X}_{\mathrm{Sp}} \mathrm{Sp}$ & & & & 0.020 & \pm & 0.002 & 0.0066 & \pm & 0.0005 & 0.034 & \pm & 0.008 \\
\hline $\mathrm{X}_{\mathrm{He}} \mathrm{Sp}$ & & & & 0.06 & \pm & 0.01 & 0.022 & \pm & 0.003 & 0.10 & \pm & 0.01 \\
\hline $\mathrm{X}_{\mathrm{Uv}} \mathrm{sp}$ & & & & 0.120 & \pm & 0.007 & 0.62 & \pm & 0.06 & 0.044 & \pm & 0.009 \\
\hline $\mathrm{X}_{\mathrm{Mfr}} \mathrm{Sp}$ & & & & 0.126 & \pm & 0.009 & 0.15 & \pm & 0.02 & 0.13 & \pm & 0.04 \\
\hline $\mathrm{X}_{\mathrm{Qd}} \mathrm{Sp}$ & & & & 0.012 & \pm & 0.003 & 0.01 & \pm & 0.00 & 0.01 & \pm & 0.00 \\
\hline
\end{tabular}

$\mathrm{Fe}_{2} \mathrm{O}_{3}$ calculated after the method of Droop (1987). Mole fractions are a best fit. n.a. is not available. b.d. is below detection. Uncertainty is the standard deviation of the mean (1 $\sigma_{\mathrm{m}}$ ).

mental glasses and pegmatites to rocks that are known to have an anatectic origin. Examples include migmatites, such as the leucosomes in vein-type migmatites in Archean rocks from the Grenville Front (GF), Quebec (Sawyer, 1991). The Iveland Wall outcrop (see Fig. 12 of Müller et al., 2017b) and the Grenville Front, Quebec leucosomes (see Fig. 3d of Sawyer, 1991) have similar textural relationships to their respective host rock. Sawyer (1991) concluded that the Grenville Front leucosomes are the result of equilibrium partial melting, with a garnet and hornblende residue, and migration and intrusion of those melts into the host rock as vein networks. The leucosomes (GF) have strong LREE enrichment, as well as a lack of europium anomaly. The REE patterns of the leucosomes (GF) and the majority of the Evje-Iveland pegmatites are not similar. However, they are similar to the higher pressure ( $>800 \mathrm{MPa}$ ) experiments of Rapp et al. (1991), wherein garnet is stable. It is important to note that the $800 \mathrm{MPa}$ experiments of Rapp et al. (1991) are not LREE enriched and have flat REE patterns with no europium anomalies, which are similar to the experimental glasses in this study. It can be concluded that the LREE enrichment and HREE depletion in the leucosomes (GF) of the vein-type migmatites is a consequence of garnet in the residue (e.g. Halla, 2020). If the leucosomes (GF) were generated at lower pressures, wherein garnet was not stable, they would have similar REE patterns to both the $800 \mathrm{MPa}$ experiments of Rapp et al. (1991), the experimental glasses of this study, and the Iveland Wall sample (Snook, 2014). Thus, it is suggested that the felsic material at the Iveland Wall has a similar petrogenesis to the leucosomes in the vein-type migmatites of the Grenville Front, albeit at lower pressures. The petrogenetic sequence of the Iveland Wall outcrop would then include equilibrium partial melting of a basaltic like material with hornblende clinopyroxene in the residue followed by melt migration and intrusion of that melt into the host rock. This is supported by the REE patterns of the experimental glasses derived in this study; however, the REE patterns do not support formation of rare-element pegmatites by direct anatexis of amphibolite. The REE patterns of the Hvringsvatnet granites are similar to the REE patterns of the leucosomes from the Grenville Front. Generation of a partial melt as noted above, followed by magmatic differentiation may result in a melt that has a REE pattern similar to the Hvringsvatnet granites. Further differentiation may ultimately produce a melt that has a similar 
Table 9

Major element composition and formulas of starting and run product apatite.

Expand

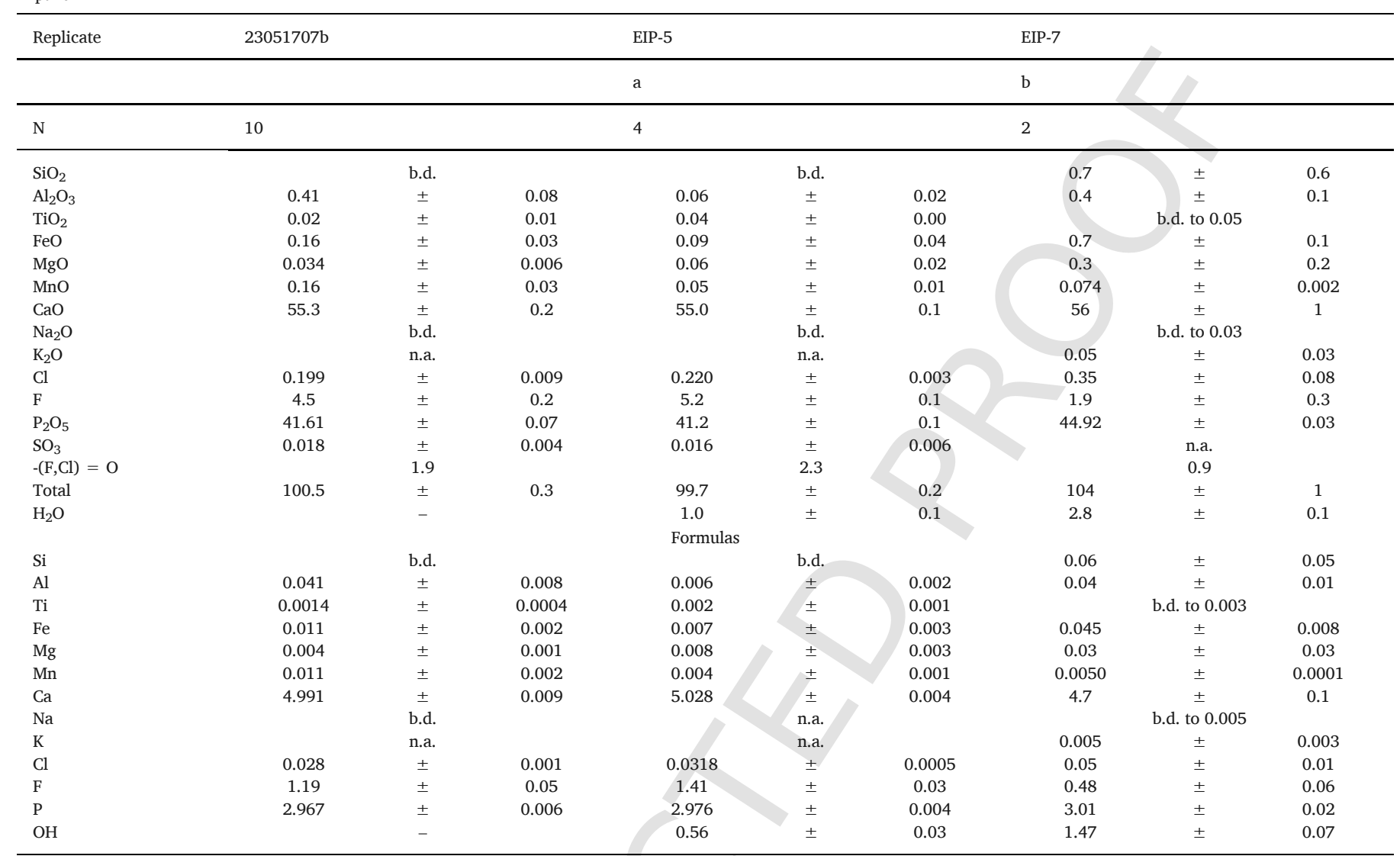

Table 10

Mineralogy of run products (mass \%).

Expand

\begin{tabular}{|c|c|c|c|c|c|c|c|c|c|c|}
\hline Replicate & $23051707 b$ & EIP-4 & & EIP-5 & & EIP-7 & & EIP-8 & EIP-9 & \\
\hline & & a & & a & $\mathrm{b}$ & a & $\mathrm{b}$ & $\mathrm{b}$ & $\mathrm{a}$ & $\mathrm{b}$ \\
\hline Glass & $0 \%$ & $37.5 \%$ & $36.2 \%$ & $82.6 \%$ & $62.0 \%$ & $13.1 \%$ & $8.0 \%$ & $23.2 \%$ & $60.8 \%$ & $34.2 \%$ \\
\hline Plagioclase (Low Ca) & $29 \%$ & $0.0 \%$ & $0.0 \%$ & $0.0 \%$ & $15.8 \%$ & $0.0 \%$ & $18.2 \%$ & $0.0 \%$ & $0.0 \%$ & $0.0 \%$ \\
\hline Plagioclase (High Ca) & $0 \%$ & $0.0 \%$ & $0.0 \%$ & $4.6 \%$ & $0.0 \%$ & $15.5 \%$ & $2.2 \%$ & $20.3 \%$ & $0.0 \%$ & $23.8 \%$ \\
\hline Amphibole & $70 \%$ & $1.2 \%$ & $13.6 \%$ & $0.0 \%$ & $0.0 \%$ & $70.5 \%$ & $70.5 \%$ & $29.6 \%$ & $0.0 \%$ & $0.0 \%$ \\
\hline Pyroxene (High Al) & $0 \%$ & $43.7 \%$ & $37.6 \%$ & $0.0 \%$ & $0.0 \%$ & $0.0 \%$ & $0.0 \%$ & $18.0 \%$ & $39.2 \%$ & $0.0 \%$ \\
\hline Pyroxene (Low Al) & $0 \%$ & $0.0 \%$ & $0.0 \%$ & $2.0 \%$ & $5.6 \%$ & $0.9 \%$ & $0.0 \%$ & $0.0 \%$ & $0.0 \%$ & $42.0 \%$ \\
\hline Olivine 1 & $0 \%$ & $0.0 \%$ & $12.6 \%$ & $10.7 \%$ & $14.6 \%$ & $0.0 \%$ & $0.0 \%$ & $0.0 \%$ & $0.0 \%$ & $0.0 \%$ \\
\hline Olivine 2 & $0 \%$ & $17.5 \%$ & $0.0 \%$ & $0.0 \%$ & $0.0 \%$ & $0.0 \%$ & $0.0 \%$ & $0.0 \%$ & $0.0 \%$ & $0.0 \%$ \\
\hline Biotite & $0 \%$ & $0.0 \%$ & $0.0 \%$ & $0.0 \%$ & $0.0 \%$ & $0.0 \%$ & $0.0 \%$ & $0.0 \%$ & $0.0 \%$ & $0.0 \%$ \\
\hline Apatite & $0 \%$ & $0.0 \%$ & $0.0 \%$ & $0.0 \%$ & $2.0 \%$ & $0.0 \%$ & $0.8 \%$ & $0.0 \%$ & $0.0 \%$ & $0.0 \%$ \\
\hline Spinel & $1 \%$ & $0.0 \%$ & $0.0 \%$ & $0.0 \%$ & $0.0 \%$ & $0.0 \%$ & $0.3 \%$ & $9.0 \%$ & $0.0 \%$ & $0.0 \%$ \\
\hline
\end{tabular}

See text for details of calculation.

REE pattern to the pegmatites at the Evje-Iveland pegmatite field, whereas direct anatexis cannot.

The Kåbuland pegmatite is unique among the pegmatites in that it is the only pegmatite, where data are available, to have a strong LREE enrichment, HREE depletion, and no europium anomaly. The depletion in HREE may indicate the presence of garnet in the residue and thus a deeper or different source. Additionally, Walker et al. (1989) noted that REE patterns of pegmatites, such as the one at Kåbuland are due to 


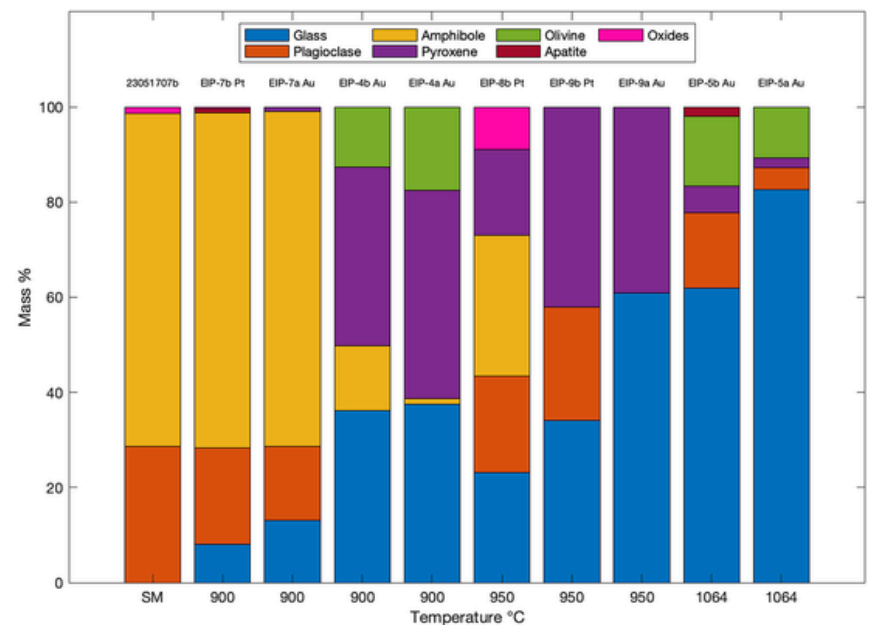

Fig. 9. Mineralogy in mass $\%$ of the run products and starting material as determined by a constrained linear least-squares method (see text for details) plotted as stacked bars. Along the $\mathrm{x}$-axis is the temperature of the experiments. From left to right, bars are plotted in order of increasing temperature and increasing proportion of glass. SM is the starting material. Biotite is present in a model abundance of $<<1 \%$ in EIP-4a and EIP-4b and is excluded from the figure.

the initial crystallization of wall zone, wherein the crystallization is isolated and that they can reflect the REE pattern of the plagioclase present. This observation in combination with potential sampling bias (i.e. modally more plagioclase and quartz than is representative of the bulk pegmatite) provides one explanation to the unique REE pattern of the Kåbuland pegmatite.

Based on the REE patterns, there is only evidence of partial melting of the host amphibolite without a need for magmatic differentiation at the Iveland Wall. For the remaining pegmatite border zones where data are available (excluding the unique Kåbuland pegmatite), there is no LREE enrichment and strong negative europium anomalies are not observed in the experimental glasses in this study or in previous studies. Taking into consideration the low concentrations of scandium and the REEs in the run product glasses of this study, and the differences among the REE patterns as compared to the pegmatites, there is little evidence to support the formation of the rare-element pegmatites within the Evje-Iveland pegmatite field by direct anatexis of the host amphibolite and consideration of an alternative petrogenesis, such as magmatic differentiation, is warranted.

\subsection{Solidus temperature}

The vapor-absent solidus temperature for the amphibolite of approximately $900{ }^{\circ} \mathrm{C}$ determined in this study is significantly higher than the temperatures that have been suggested for pegmatite emplacement. As mentioned above, Müller et al. (2015) determined an emplacement temperature of $\sim 613^{\circ} \pm 70{ }^{\circ} \mathrm{C}$ by using titanium-in-quartz thermometry, which is, at present, interpreted to be the most accurate determination of the temperature of emplacement. Other emplacement temperatures of 550 to $600{ }^{\circ} \mathrm{C}$ as estimated from the metamorphic aureole surrounding the Rogaland complex (Müller et al., 2015) are not well constrained. This is because the estimates of the temperature $\left(\sim 750{ }^{\circ} \mathrm{C}\right)$ near the edge of the metamorphic aureole near the Rogaland complex extend, at most, a few tens of kilometers away from the contact of the intrusion (Jansen et al., 1985; Westphal et al., 2003), whereas the Evje-Iveland pegmatite field is $\sim 100 \mathrm{~km}$ away from the intrusion. Thus, when discussing the temperature of emplacement only the temperature determined by titanium-in-quartz thermometry will be considered. It can be argued that the solidus temperature of the host and pegmatite emplacement temperature will not be consistent if the melt was generated distal to the emplacement location of the pegmatites, with significant melt migration. This is common in the generation of granitic pegmatites as the melt migrates away from the source pluton and crystallizes as a result of undercooling during emplacement in a colder host rock (London, 2008). However, Müller et al. (2015) suggested that melting and pegmatite emplacement occurred in approximately the same location. If pegmatite formation by direct anatexis is assumed, it could then be concluded that the temperature of emplacement and the temperature of amphibolite melting should be approximately the same, which is not supported by the experiments conducted in this study. This discrepancy in solidus and emplacement temperature is problematic for the formation of the pegmatites by anatexis.

If anatexis occurred at $613^{\circ} \pm 70^{\circ} \mathrm{C}$, and if it was the driving mechanism for pegmatite formation the solidus temperature would need to be lowered by either melting at higher pressures or by fluid fluxing. In the case of higher pressure, an increase in pressure, such that garnet is stable instead of clinopyroxene (between $700 \mathrm{MPa}$ and $1 \mathrm{GPa}$ ), can reduce the solidus temperature to $\sim 650{ }^{\circ} \mathrm{C}$ at $700 \mathrm{MPa}$ (Wyllie and

Table 11

Residuals of least-squares calculation.

Expand

\begin{tabular}{|c|c|c|c|c|c|c|c|c|c|c|}
\hline Replicate & $23051707 b$ & EIP-4 & & EIP-5 & & EIP-7 & & EIP-8 & EIP-9 & \\
\hline & & $\mathrm{a}$ & $\mathrm{b}$ & a & $\mathrm{b}$ & a & $\mathrm{b}$ & $\mathrm{b}$ & $\mathrm{a}$ & $\mathrm{b}$ \\
\hline $\mathrm{SiO}_{2}$ & -1.07 & -0.74 & -0.81 & 0.32 & -0.55 & -0.75 & -0.86 & 0.33 & -4.77 & -5.92 \\
\hline $\mathrm{Al}_{2} \mathrm{O}_{3}$ & 0.67 & 1.15 & 0.31 & -0.11 & 0.46 & -0.30 & -0.17 & 0.18 & 1.98 & 0.47 \\
\hline $\mathrm{TiO}_{2}$ & -0.46 & 0.01 & 0.14 & 0.00 & 0.48 & 0.10 & 0.02 & -1.92 & 0.33 & 0.48 \\
\hline $\mathrm{FeO}$ & -0.56 & 3.37 & 5.23 & -0.27 & 0.13 & -0.68 & -0.95 & 1.01 & 3.27 & 8.22 \\
\hline $\mathrm{MgO}$ & 0.63 & -2.49 & -3.54 & 0.08 & -0.04 & -0.14 & 0.41 & 0.19 & 1.73 & 0.22 \\
\hline $\mathrm{MnO}$ & -0.03 & 0.01 & 0.03 & -0.01 & 0.01 & 0.01 & 0.00 & 0.04 & -0.01 & 0.00 \\
\hline $\mathrm{CaO}$ & -0.27 & 0.41 & 0.13 & -0.32 & 0.33 & -0.19 & -0.81 & -0.02 & -1.46 & -3.88 \\
\hline $\mathrm{Na}_{2} \mathrm{O}$ & -0.36 & 0.15 & -1.11 & -0.14 & -0.53 & -0.09 & -0.05 & 0.42 & 0.26 & 0.47 \\
\hline $\mathrm{K}_{2} \mathrm{O}$ & 0.23 & -0.07 & -0.17 & 0.01 & 0.10 & -0.20 & 0.02 & 0.02 & -0.40 & -0.04 \\
\hline $\mathrm{Cl}$ & 0.00 & -0.19 & -0.11 & -0.05 & -0.06 & -0.07 & -0.07 & -0.06 & -0.07 & -0.08 \\
\hline $\mathrm{F}$ & 0.16 & 0.07 & -0.02 & -0.09 & -0.13 & 0.09 & 0.12 & 0.15 & 0.09 & 0.14 \\
\hline $\mathrm{P}_{2} \mathrm{O}_{5}$ & 0.07 & -0.04 & -0.04 & -0.02 & -0.84 & 0.06 & -0.36 & -0.04 & -0.08 & -0.04 \\
\hline SSQ & 2.82 & 19.66 & 41.91 & 0.32 & 1.89 & 1.24 & 2.65 & 5.10 & 42.86 & 118.48 \\
\hline
\end{tabular}

Negative values indicate an over estimation of the given oxide. Positive values indicate and underestimation of the given oxide. SSQ is sum of squares 


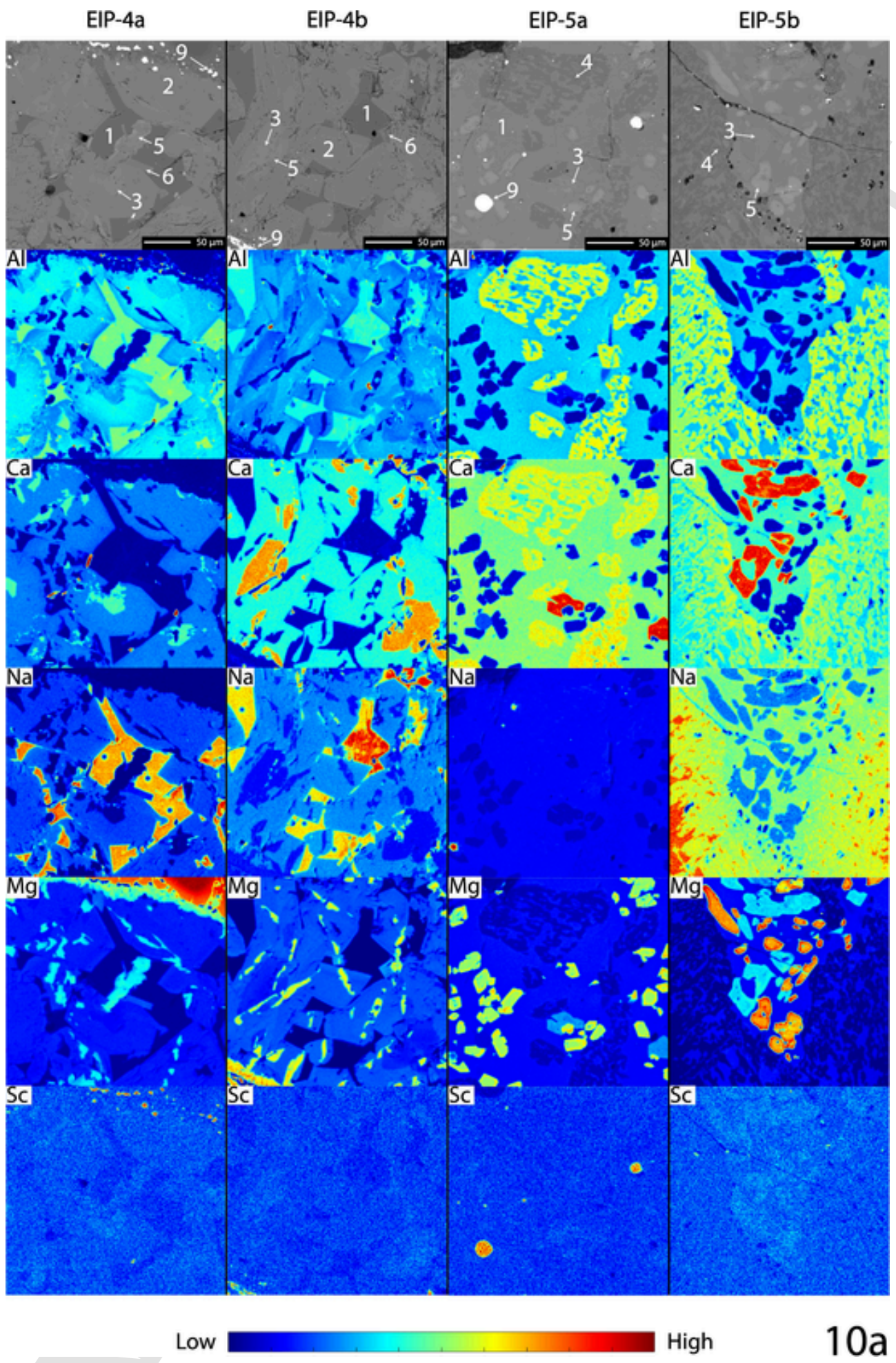

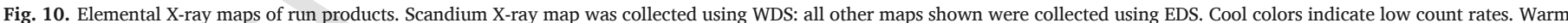

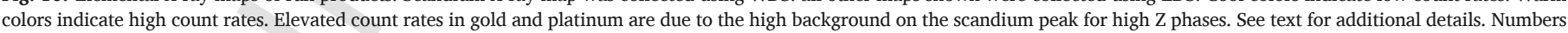
indicate the phases: $1=$ Glass; $2=$ Amphibole; $3=$ Pyroxene; $4=$ Plagioclase; $5=$ Olivine; $6=$ Biotite; $7=$ Oxides; $8=$ Apatite; $9=$ Gold; $10=$ Platinum.

Wolf, 1993). The stabilization of garnet in the residue would result in a REE pattern of the melt would be LREE enriched and HREE depleted (e.g. Rapp et al., 1991), similar to that at the Kåbuland pegmatite (BZ), but inconsistent with the REE patterns of the pegmatites. Additionally, because scandium is compatible in garnet with the degree of compatibility being depending on composition (Chassé et al., 2018;
Steffenssen et al., 2019; Van Westrenen et al., 1999), scandium could be further depleted in the melt. Higher pressures would then necessitate a source rock that was more trace element-rich (Sc and HREEs) than the host amphibolite. A more fertile source would ensure that the partial melt could, through further differentiation or secondary processes, saturate with thortveitite and produce the REE patterns seen 


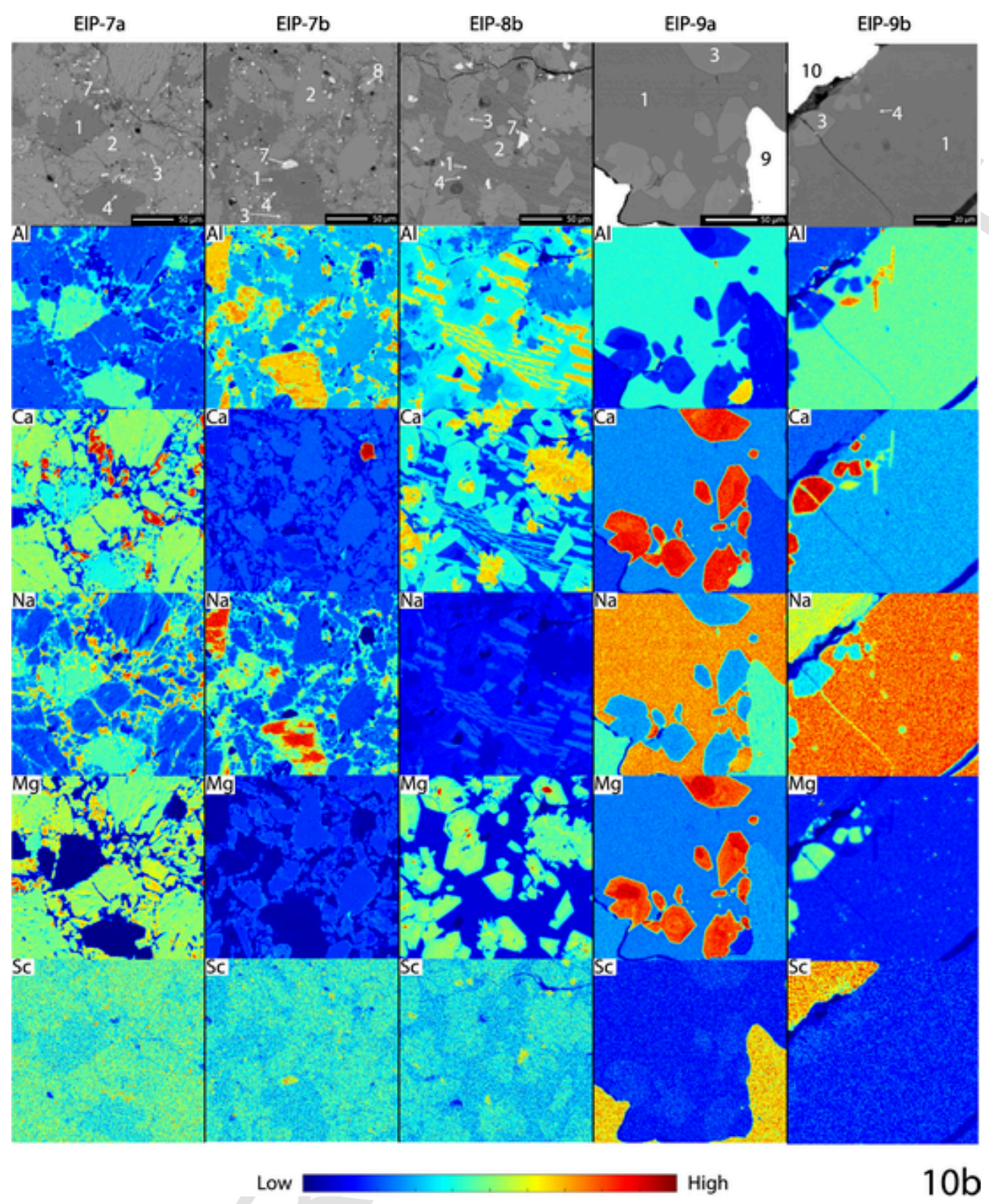

in the pegmatites. In the case of fluid fluxing the amphibolite, fluxing agents $\left(\mathrm{H}_{2} \mathrm{O}, \mathrm{F}, \mathrm{B}, \mathrm{Li}\right.$ etc.) may reduce the solidus temperature to the wet basalt solidus, which is $\sim 700{ }^{\circ} \mathrm{C}$ at $500 \mathrm{MPa}$ (e.g. Holloway and Burnham, 1972; Tuthill, 1968; Yoder and Tilley, 1962). An externally derived fluid could also introduce trace elements, such as scandium, that would otherwise be sequestered in the residue during partial melting. However, evidence for the introduction of an external fluid that would enable lower temperature melting during the time of pegmatite emplacement is minimal and the contact between the pegmatite and amphibolite is sharp with little contact metamorphism (Snook, 2014). There is some evidence for the presence of a fluid during the late stages of pegmatite formation Müller et al. (2018), as well as hydrothermal alteration after emplacement (Müller et al., 2015; Müller et al., 2017a; Snook, 2014); however, these fluids are unlikely to play a role in lowering the solidus temperature. Thus, it is not apparent that melting of the amphibolite was fluxed by an external fluid.

\subsection{Petrogenetic model}

The introduction of an externally derived melt must be considered for the generation of the Evje-Iveland pegmatites. The experiments conducted in this study offer no support for the hypothesis that the pegmatites were derived by direct anatexis of host amphibolite alone, because the melt compositions (major and trace elements; particularly scandium and the REEs) and the solidus temperatures are not consistent with previous observations. Thus, the pegmatite-forming melt cannot be a result of direct anatexis of the host amphibolite. Instead, the source is likely an externally derived melt generated by melting of a scandium-rich source rock (several hundreds of ppm scandium), differentiation of that melt resulting in enrichment in scandium and volatiles, and emplacement of that melt in the host amphibolite. A scandium-rich source rock is required to generate a melt that is capable of saturation with thortveitite upon emplacement. This melt must be scandium-rich compared to average felsic rocks (the average scandium concentration in the upper continental crust is 14 ppm; Rudnick and 
Table 12

Trace elements in run products and starting material.

\begin{tabular}{|c|c|c|c|c|c|c|c|c|c|c|c|c|c|c|c|c|c|c|c|c|c|c|c|}
\hline \multirow[b]{2}{*}{ Replicate } & \multicolumn{23}{|l|}{ Glass } \\
\hline & \multicolumn{6}{|l|}{ EIP-4 } & \multicolumn{6}{|l|}{ EIP-5 } & \multicolumn{4}{|l|}{ EIP-7 } & EIP-8 & \multicolumn{6}{|l|}{ EIP-9 } \\
\hline & \multicolumn{3}{|l|}{ a } & \multicolumn{3}{|l|}{$\mathrm{b}$} & \multicolumn{3}{|l|}{ a } & \multicolumn{3}{|c|}{$\mathrm{b}$} & \multicolumn{3}{|l|}{ a } & $\mathrm{b}$ & $\mathrm{b}$ & \multicolumn{3}{|l|}{ a } & \multicolumn{3}{|l|}{$\mathrm{b}$} \\
\hline $\mathrm{N}$ & \multicolumn{3}{|l|}{2} & \multicolumn{3}{|l|}{3} & 2 & & & 3 & & & 2 & & & 1 & 1 & 2 & 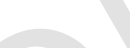 & $\gamma$ & 2 & & \\
\hline $\mathrm{Li}$ & 37 & \pm & 7 & 35 & \pm & 2 & & b.d. to 17.9 & & & b.d. & & & b.d. & & b.d. & 20 & 27 & \pm & 4 & 28 & \pm & 7 \\
\hline Sc & & b.d. & & & b.d. & & 37 & \pm & 5 & 50 & \pm & 10 & & b.d. & & b.d. & b.d. & & b.d. & $\gamma$ & & b.d. to 16.3 & \\
\hline $\mathrm{v}$ & & b.d. & & & b.d. to 67.9 & & 300 & \pm & 70 & 214 & \pm & 3 & & b.d. & & b.d. & 66 & 56.5 & \pm & 0.4 & 240 & \pm & 30 \\
\hline Ga & 70 & \pm & 1 & 70 & \pm & 20 & 70 & \pm & 20 & 40 & \pm & 5 & 51 & \pm & 21 & 49 & 115 & 200 & \pm & 2 & 180 & \pm & 20 \\
\hline Ge & & b.d. & & & b.d. & & & b.d t 12.9 & & & b.d. & & & b.d. & & 37.5 & b.d. & & b.d. & & & b.d. & \\
\hline $\mathrm{Rb}$ & 35 & \pm & 5 & 53 & \pm & 7 & 13 & \pm & 3 & 5 & \pm & 1 & 6 & \pm & 3 & b.d. & 29 & 45.6 & \pm & 0.5 & 47 & \pm & 6 \\
\hline $\mathrm{Sr}$ & 230 & \pm & 40 & 270 & \pm & 50 & 200 & \pm & 50 & 195 & \pm & 29 & 400 & \pm & 100 & 828 & 122 & 225 & \pm & 3 & 210 & \pm & 10 \\
\hline $\mathrm{Y}$ & 3 & \pm & 2 & 5 & \pm & 3 & 22 & \pm & 5 & 26 & \pm & 1 & & b.d. to 0.7 & & b.d. & 14 & 31 & \pm & 1 & 34 & \pm & 2 \\
\hline $\mathrm{Zr}$ & & b.d. to 11.1 & & 13 & \pm & 6 & 43 & \pm & 8 & 42 & \pm & 4 & & b.d. & & b.d. & 105 & 123.5 & \pm & 0.4 & 150 & \pm & 20 \\
\hline $\mathrm{Nb}$ & & b.d. to 0.2 & & & b.d. to 0.9 & & 3 & \pm & 1 & 2.9 & \pm & 0.7 & 0.10 & \pm & 0.03 & b.d. & 5.7 & 6.5 & \pm & 0.6 & 7 & \pm & 2 \\
\hline $\mathrm{Cd}$ & & b.d. to 1.6 & & & b.d. & & & b.d. to 2 & & & b.d. & & & b.d. to 0.3 & & b.d. & b.d. & & b.d. & & & b.d.to 1.4 & \\
\hline In & & b.d. & & 0.08 & \pm & 0.01 & & b.d. & & & b.d. to 0.1 & & & b.d. to 0.3 & & b.d. & b.d. & & b.d. & & & b.d. & \\
\hline Sn & & b.d. & & & b.d. & & & b.d. & & & b.d. & & & b.d. & & b.d. & b.d. & & b.d. & & & b.d. & \\
\hline Cs & 2.70 & \pm & 0.08 & 3.2 & \pm & 0.5 & & b.d. to 0.4 & & & b.d. & & & b.d. & & b.d. & b.d. & 1.95 & \pm & 0.06 & 2.0 & \pm & 0.6 \\
\hline $\mathrm{La}$ & 10 & \pm & 8 & 12 & \pm & 6 & 18 & \pm & 5 & 10 & \pm & 5 & 1.4 & \pm & 0.3 & 3.5 & 18 & 12.8 & \pm & 0.5 & 18.2 & \pm & 0.6 \\
\hline $\mathrm{Ce}$ & 5 & \pm & 4 & 5 & \pm & 3 & 16 & \pm & 5 & 15 & \pm & 2 & 1.9 & \pm & 0.4 & 3.9 & 31 & 35.0 & \pm & 0.2 & 36 & \pm & 2 \\
\hline $\operatorname{Pr}$ & & b.d. to 0.3 & & 0.8 & \pm & 0.5 & 3 & \pm & 1 & 2.9 & \pm & 0.4 & 0.24 & \pm & 0.09 & 0.5 & 3.4 & 4.8 & \pm & 0.3 & 5.2 & \pm & 0.7 \\
\hline $\mathrm{Nd}$ & & b.d. to 1.5 & & & b.d. to 5.5 & & 14 & \pm & 4 & 15 & \pm & 1 & 0.42 & \pm & 0.06 & 0.7 & 13 & 23.3 & \pm & 0.9 & 22.0 & \pm & 0.7 \\
\hline $\mathrm{Sm}$ & & b.d to 0.5 & & & b.d. to 2.2 & & 5 & \pm & 2 & 4.5 & \pm & 0.4 & & 0.3 & & 0.9 & b.d. & 5.3 & \pm & 0.2 & 5.0 & \pm & 0.4 \\
\hline $\mathrm{Eu}$ & & b.d. to 0.3 & & & b.d. to 0.6 & & 1.8 & \pm & 0.9 & 1.44 & \pm & 0.09 & & b.d. & & 0.7 & 1.2 & 2.03 & \pm & 0.09 & 2.00 & \pm & 0.06 \\
\hline $\mathrm{Gd}$ & & b.d. & & & b.d. to 1.4 & & & b.d. to 3 & 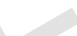 & 4.4 & \pm & 0.4 & 0.5 & \pm & 0.2 & b.d. & b.d. & & 6.7 & & 5.0 & \pm & 0.5 \\
\hline $\mathrm{Tb}$ & 0.05 & \pm & 0.01 & 0.2 & \pm & 0.1 & & b.d. to 1 & & 0.85 & \pm & 0.02 & 0.03 & \pm & 0.01 & 0.3 & b.d. & 0.89 & \pm & 0.01 & 0.94 & \pm & 0.01 \\
\hline Dy & 0.3 & \pm & 0.2 & & b.d. to 0.5 & & 5 & \pm & 1 & 5.3 & \pm & 0.5 & & b.d. & & 0.8 & 4.0 & 5.1 & \pm & 0.9 & 5.7 & \pm & 0.6 \\
\hline Ho & 0.10 & \pm & 0.08 & & b.d. to 0.4 & & 0.8 & \pm & 0.1 & 1.0 & \pm & 0.1 & & b.d. & & b.d. & 0.4 & 1.05 & \pm & 0.08 & 1.1 & \pm & 0.1 \\
\hline $\mathrm{Er}$ & & b.d. to 0.2 & & & b.d. to 0.6 & 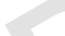 & 2.2 & \pm & 0.3 & 2.6 & \pm & 0.1 & & b.d. & & b.d. & 1.4 & 3.36 & \pm & 0.06 & 3.4 & \pm & 0.2 \\
\hline $\mathrm{Tm}$ & & b.d. to 0.02 & & 0.2 & \pm & 0.1 & 0.39 & \pm & 0.02 & 0.34 & \pm & 0.05 & 0.02 & \pm & 0.01 & b.d. & b.d. & 0.45 & \pm & 0.03 & 0.53 & \pm & 0.01 \\
\hline $\mathrm{Yb}$ & 0.6 & \pm & 0.2 & 0.8 & \pm & 0.4 & 2.4 & \pm & 0.4 & 2.2 & \pm & 0.2 & 0.3 & \pm & 0.1 & b.d. & 1.2 & 3.1 & \pm & 0.6 & 2.43 & \pm & 0.03 \\
\hline $\mathrm{Lu}$ & 0.03 & \pm & 0.01 & & b.d. to 0.3 & & & b.d. to 0.1 & & 0.28 & \pm & 0.09 & & b.d. & & b.d. & 0.1 & 0.63 & \pm & 0.02 & 0.38 & \pm & 0.05 \\
\hline $\mathrm{Hf}$ & & b.d. & & $\mathrm{a}$ & b.d. to 0.5 & & 1.1 & \pm & 0.3 & 1.309 & \pm & 0.002 & 0.6 & \pm & 0.5 & b.d. & 2.3 & 4.0 & \pm & 0.3 & 3.7 & \pm & 0.6 \\
\hline $\mathrm{Ta}$ & & b.d. to 0.02 & & & b.d. to 0.2 & & 0.21 & \pm & 0.08 & 0.16 & \pm & 0.03 & 0.04 & \pm & 0.03 & b.d. & 0.4 & & b.d. to 0.6 & & 0.30 & \pm & 0.01 \\
\hline & Pyroxene & & & & 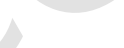 & & & & & & & & & & & & Plagioclase & & Olivine & & & & \\
\hline Replicate & EIP-4 & & & EIP. & & & & & & EIP-7 & EIP-8 & & & EIP-9 & & & $23051707 \mathrm{~b}$ & & EIP-4 & EIP-5 & & & \\
\hline & a & b & & a & & & $\mathrm{b}$ & & & a & $\mathrm{b}$ & & a & a & & $\mathrm{b}$ & - & & a & a & $\mathrm{b}$ & & \\
\hline $\mathrm{N}$ & 1 & 2 & & 2 & & & 2 & & & 1 & 2 & & 2 & 2 & & 1 & 2 & & 1 & 1 & 2 & & \\
\hline $\mathrm{Li}$ & b.d. & 7.8 & & b.d. & & & b.d. & & & b.d. & 9 & \pm & $\mathrm{b}$ & b.d. & & b.d. & b.d. to 2.6 & & 12 & b.d. & b.d. & & \\
\hline Sc & 98 & 110 & 30 & 90 & \pm & 10 & 82 & \pm & 2 & 54 & 97 & \pm & 1 & 105 & 6 & 120 & b.d. to 3.4 & & b.d. & 23 & b.d to & & \\
\hline $\mathrm{v}$ & 825 & 722 & 8 & 390 & \pm & 70 & 210 & \pm & 10 & 210 & 129 & \pm & 2 & 200 & 30 & 112 & b.d. & & 10 & 129 & 50 & \pm & 20 \\
\hline
\end{tabular}




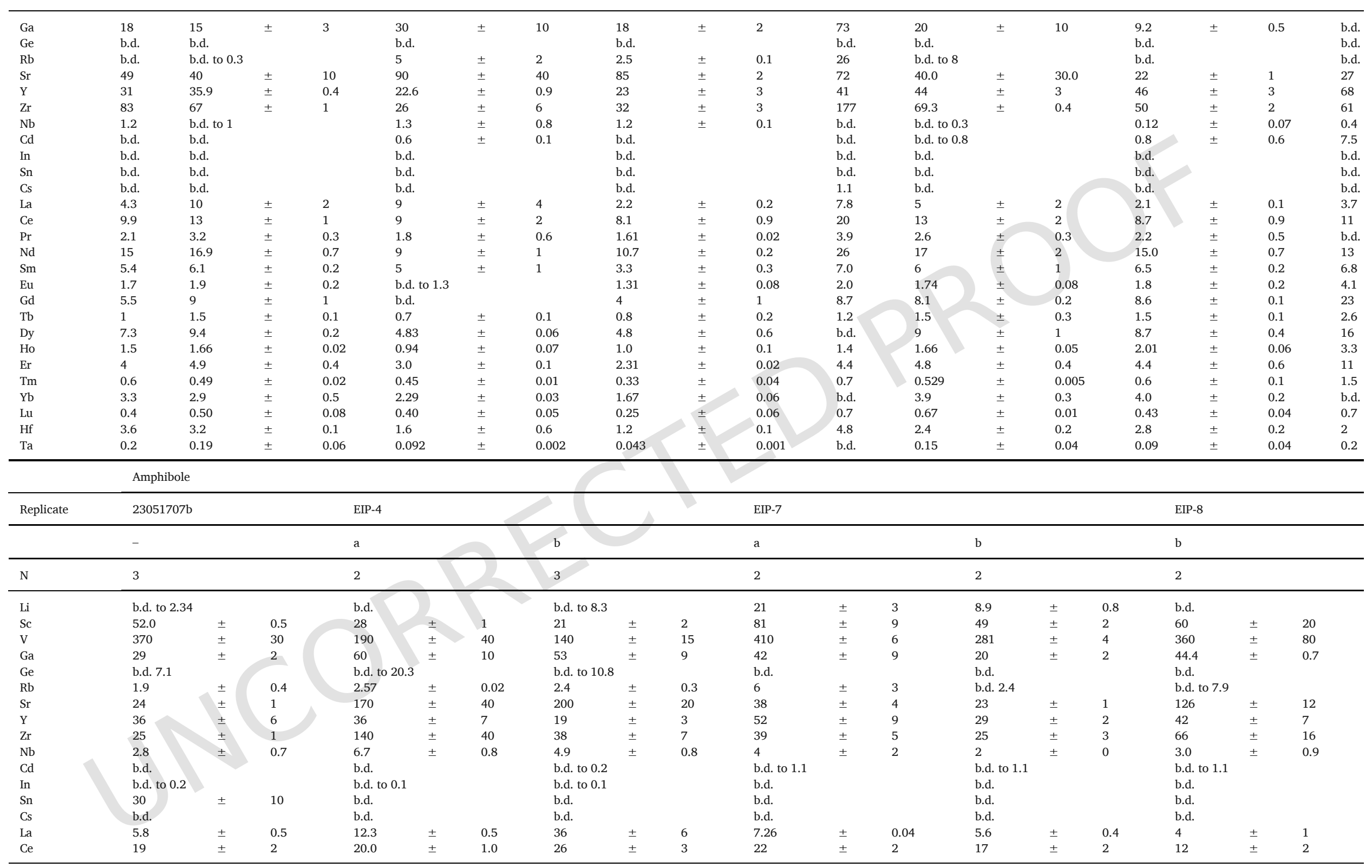




\begin{tabular}{|c|c|c|c|c|c|c|c|c|c|c|c|c|c|}
\hline $\operatorname{Pr}$ & 3.1 & \pm & 0.3 & 3.5 & \pm & 0.3 & 3.9 & \pm & 0.3 & 3.9 & \pm & 0.3 & 2.8 \\
\hline $\mathrm{Nd}$ & 16 & \pm & 2 & 19 & \pm & 2 & 19 & \pm & 4 & 25 & \pm & 5 & 13 \\
\hline $\mathrm{Sm}$ & 4.5 & \pm & 0.4 & 6 & \pm & 1 & 4.2 & \pm & 0.5 & 7 & \pm & 2 & 4.3 \\
\hline Eu & 1.5 & \pm & 0.2 & 1.5 & \pm & 0.4 & 1.4 & \pm & 0.5 & 1.86 & \pm & 0.02 & 1.40 \\
\hline $\mathrm{Gd}$ & 6 & \pm & 1 & 6 & \pm & 2 & 5.3 & \pm & 0.2 & 9 & \pm & 3 & 4.8 \\
\hline $\mathrm{Tb}$ & 0.9 & \pm & 0.1 & 1.0 & \pm & 0.3 & 0.66 & \pm & 0.08 & 1.4 & \pm & 0.3 & 0.73 \\
\hline Dy & 7 & \pm & 2 & 6 & \pm & 1 & 3.7 & \pm & 0.6 & 10 & \pm & 2 & 5.99 \\
\hline Но & 1.5 & \pm & 0.3 & 1.4 & \pm & 0.4 & 0.83 & \pm & 0.13 & 1.9 & \pm & 0.2 & 1.19 \\
\hline Er & 3.8 & \pm & 0.7 & 3.5 & \pm & 0.6 & 2.1 & \pm & 0.3 & 5.1 & \pm & 0.9 & 3.1 \\
\hline $\mathrm{Tm}$ & 0.455 & \pm & 0.005 & 0.5 & \pm & 0.1 & 0.22 & \pm & 0.02 & 0.7 & \pm & 0.1 & 0.43 \\
\hline $\mathrm{Yb}$ & 3.7 & \pm & 0.3 & 4 & \pm & 1 & 2.2 & \pm & 0.3 & 5.2 & \pm & 0.7 & 3.0 \\
\hline $\mathrm{Lu}$ & 0.39 & \pm & 0.03 & 0.46 & \pm & 0.02 & 0.30 & \pm & 0.04 & 0.7 & \pm & 0.3 & 0.43 \\
\hline $\mathrm{Hf}$ & 1.40 & \pm & 0.03 & 4 & \pm & 1 & 1.2 & \pm & 0.2 & 2.402 & \pm & 0.003 & 1.00 \\
\hline $\mathrm{Ta}$ & 0.12 & \pm & 0.02 & 0.8 & \pm & 0.2 & 0.42 & \pm & 0.08 & 0.26 & \pm & 0.06 & b.d. to 0.12 \\
\hline
\end{tabular}

b.d. is below detection. Uncertainty is the standard deviation of the mean $\left(1 \sigma_{\mathrm{m}}\right)$. 

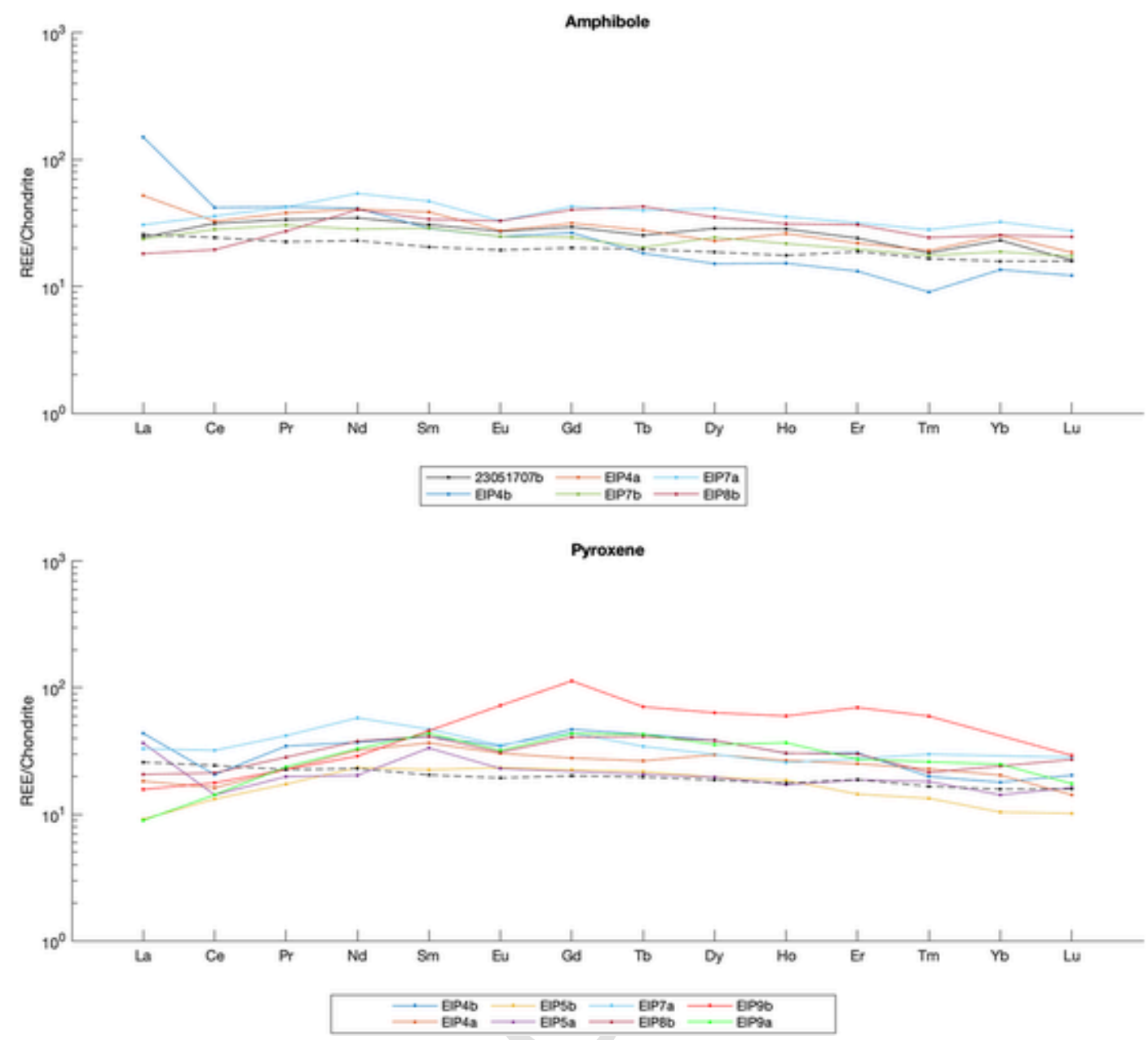

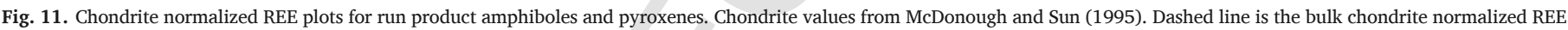
pattern for the starting materials (sample 23051707b).

Gao, 2003) although the melt will be scandium-poor relative to any residue generated during melting. Additionally, the residue must be garnet-absent and contain plagioclase to be consistent with the observed REE patterns of the majority of the Evje-Iveland pegmatites (Fig. 12). These constraints make the assumption that the source material has not been previously depleted in HREEs or already has a negative europium anomaly and that these features are derived from the partial meting event.

The primary issue with the formation of scandium-rich or other REE-rich felsic melts by fractional crystallization is that concentrating these elements is a difficult process. This is due to the fact that scandium and other rare-earth elements are generally compatible in some minerals, particularly moderately abundant ferromagnesian minerals such as amphibole, pyroxene, and biotite (Gion, 2020; Mahood and Hildreth, 1983; Nandedkar et al., 2016; Nash and Crecraft, 1985-). In order to produce scandium or REErich melts by fractional crystallization, the crystallization products must contain minimal ferromagnesian minerals. If the melt does crystallize significant amounts of ferromagnesian minerals then there must be some processes or some conditions that allow scandium to behave incompatibly in these phases. Presently, the most probable explanation for this is that the scandium and/or REEs are strongly complexed with anions that prefer to stay in the melt, and thus prevent large amounts of these elements from entering the crystalline phases. In the case of scandium, fluorine is of particular interest as scandium-bearing deposits have often been associated with fluorine-rich fluids (Gramaccioli et al., 2004; Guastoni et al.,
2012; Kempe and Wolf, 2006; Pezzotta et al., 2005). Scandium-fluoride complexes would then allow scandium to behave incompatibly and be concentrated in the melt. The decrease in partition coefficients of trace elements with increasing fluorine content of the melt has been demonstrated in minerals such as pyroxene and amphibole due to complexing with the metal and altering the structure of the melt (Adam et al., 1993; Beard et al., 2020; Iveson et al., 2018; Schaller et al., 1992). Additional data are needed to fully understand the behavior of scandium in volatile-rich systems, especially those that are fluorine-rich; however, a scandium-rich cumulate fluxed by a fluid and partially melted and then undergoes magmatic differentiation is, in light of this study, the best scenario for forming a scandium-rich felsic melt. This may be particularly true in the case of low-degrees of partial melting, wherein scandium and the REEs have lower mineral/melt partition coefficients due to the presence of fluorine or other volatiles in the melt. In this case low-degrees of partial melting followed by further fractionation, may enhance the pegmatite forming processes. Note that low-degree partial melting during anatexis of the host amphibolite was not able to produce trace element-rich melts and thus direct anatexis of common metamorphic rocks, even at low melt fractions is, not likely to produce rare-element pegmatites.

Thus, it is suggested that the formation of the Evje-Iveland pegmatites was the result of the partial melting of a scandium-rich source rock; followed by magmatic differentiation, wherein the crystallization products contained minor ferromagnesian minerals or the melt contains anions that strongly complex with scandium and prefer to remain in 

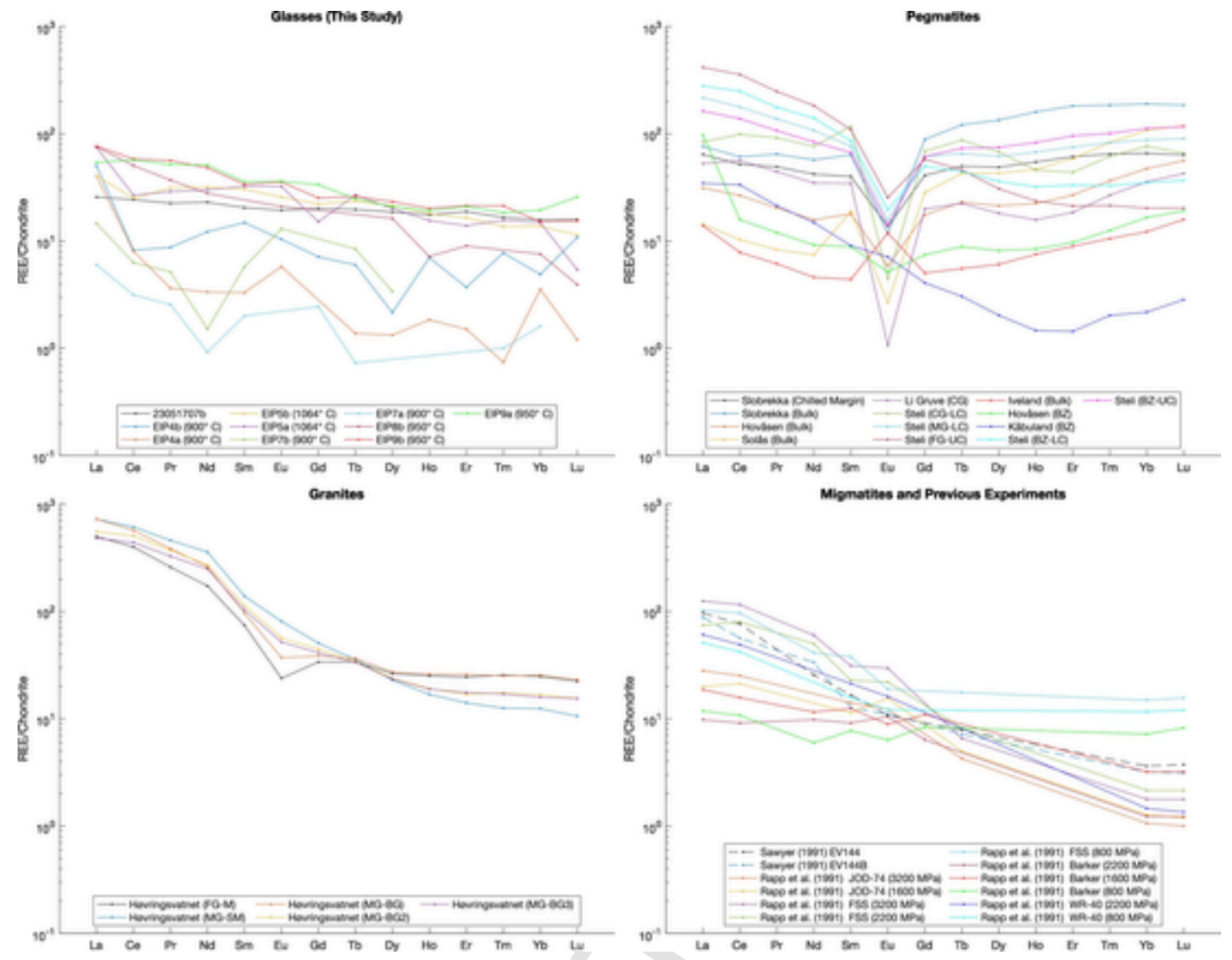

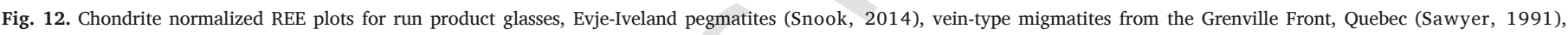

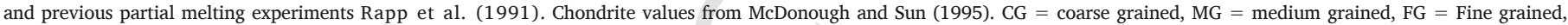
$\mathrm{LC}=$ lower contact, $\mathrm{UC}=$ upper contact, $\mathrm{BZ}=$ boarder zone, $\mathrm{M}=$ monzonite, $\mathrm{SM}=$ syenomonzonite, $\mathrm{BG}=$ biotite granite.

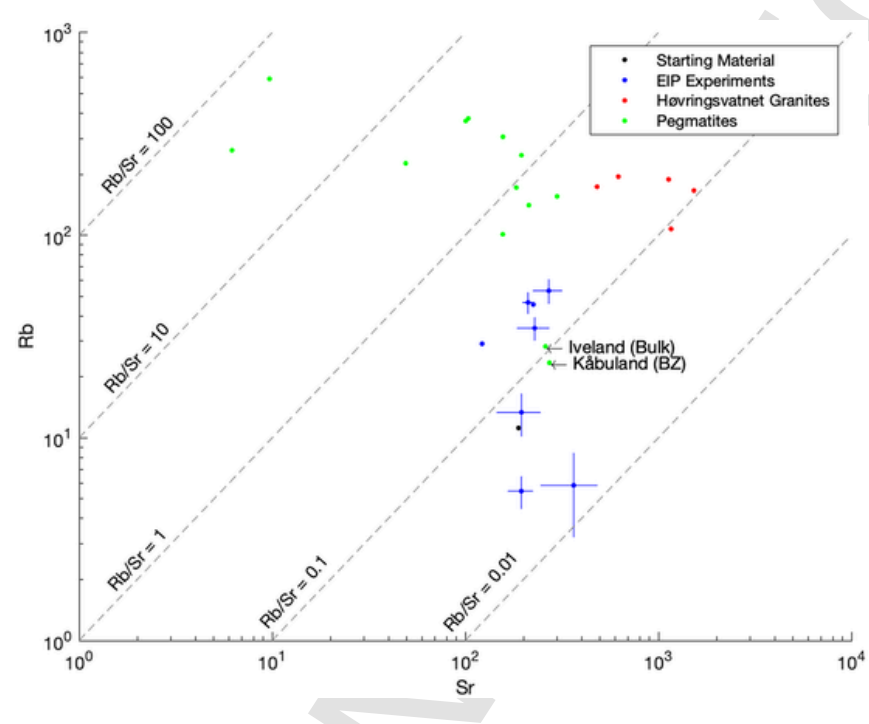

Fig. 13. Rubidium vs strontium for experiments, the Evje-Iveland pegmatites, and the Høvringsvatnet granites. Rubidium and strontium concentrations for the Evje-Iveland pegmatites and Høvringsvatnet granites are from Snook (2014).

the melt; and subsequent emplacement of a volatile- and scandium-rich melt. Additionally, during emplacement or transport of the melt away from the source rock further fractionation and internal evolution may also give rise to the zonation observed and suggested by Müller et al. (2018). This model is consistent with previous suggestions that rare-element pegmatites are the result of magmatic differentiation.
The residue of the partial melting of a mafic scandium- richsource rock would have elevated concentrations of scandium, as the residue would contain phases in which scandium is compatible, such as amphibole (Gion, 2020; Nandedkar et al., 2016). The host amphibolite is, again, unlikely to be the source of the pegmatites as it, at present, has a scandium concentration (39 ppm scandium; Rosing-Schow et al., 2018) that is typical of basaltic rocks (40 ppm scandium in MORB; Gale et al., 2013). The scandium-rich source rock likely was an ultramafic or mafic pyroxene-rich complex. Such complexes have been observed at the Kiviniemi intrusion in Finland (Ahven, 2012), as well as the Gilgai (Nyngan) and Tout Intrusive Complexes of the Fifield platinum district in eastern Australia (Chassé et al., 2017; Fairfield et al., 2018; Johan et al., 1989; Rangott et al., 2016). Scandium in these complexes is hosted in pyroxene, amphibole, and apatite, wherein the concentration of scandium can be hundreds to thousands of ppm in these minerals and hundreds of ppm in the whole rock (Ahven, 2016; Chassé et al., 2017; Johan et al., 1989; Rangott et al., 2016). A complex similar in composition to the Kiviniemi Intrusion or Gilgai and Tout Complexes may have been or is present at depth in the region of the Evje-Iveland pegmatite field and partial melting of this complex, followed by magmatic differentiation was responsible for the formation of the pegmatites. This petrogenic model is similar to that suggested by Williams-Jones and Vasyukova (2018) for the formation of scandium-rich pegmatites, with one key difference. Williams-Jones and Vasyukova (2018) accepted that the host amphibolite is the metamorphic equivalent of the source rock for the pegmatite-forming melt. In their model they suggest that a clinopyroxenite (i.e. ultramafic cumulate) was fluxed by metamorphic fluid and partial melting, wherein all of the scandium present in the clinopyroxenite was released into the 
partial melt. Williams-Jones and Vasyukova (2018) did not recognize that the efficiency that scandium is removed from the source rock into the melt, wherein that source rock or residue contains amphibole, is far below $100 \%$. In order to reach scandium concentrations in the melt high enough to be saturated with thortveitite, magmatic differentiation is required. The model proposed in this study agrees with the model of Williams-Jones and Vasyukova (2018) in that a pyroxene-rich cumulate was the source rock for the pegmatite-forming melt, but disagrees that the melt did not undergo differentiation and that the host amphibolite is the metamorphic equivalent of this pyroxene-rich cumulate.

An intrusive body that deserves further investigation as it relates to the Evje-Iveland pegmatites formation is the Flăt metadioritic suite, comprising the Mykleås diorite, the Flåt ore diorite, and the Fennefoss metagranodiorite (augen gneiss). Although, the Flåt suite is substantially older (age of $\sim 1030 \mathrm{Ma}$ ) than the Evje-Iveland pegmatites and is not particularly rich in scandium, it is unique in that it is a felsic rock that is host to a nickel deposit whose parent is a mantle-derived magma (Pedersen, 1993). This is notable because the Gilgai and Tout Complexes also contain significant amounts of nickel in addition to scandium (Chassé et al., 2017; Fairfield et al., 2018; Johan et al., 1989; Rangott et al., 2016). Thus, one hypothesis would be that the Flăt ore diorite suite that is the result of partial melting, or multiple partial melting events, of a nickel- and scandium-rich ultramafic complex that differentiated and formed two bodies: the less evolved nickel-rich Flăt ore diorite and the more evolved scandium-bearing Evje-Iveland pegmatites. More data are required to test this hypothesis; however, the close spatial association of the nickel-bearing Flăt diorite to the pegmatites is worthy of further investigation.

The role of the Høvringsvatnet granite in the formation of the pegmatites remains uncertain. The granites may be the partial melts of complexes such as the Gilgai and Tout Complexes. The pegmatites may then represent the final stages of magmatic differentiation of that partial melt or a different aliquot of melt from the same source at a younger time period. However, the Høvringsvatnet granite contains both biotite and amphibole (Pedersen, 1975), which will sequester scandium during differentiation, and have relatively low concentrations of scandium (Snook, 2014).

\section{Conclusions}

The results of partial melting experiments performed on the Evje-Iveland host amphibolite are inconsistent with the hypothesis that the Evje-Iveland pegmatites are the result of direct anatexis of that amphibolite. The solidus of the amphibolite is close to $900{ }^{\circ} \mathrm{C}$ at $500 \mathrm{MPa}$. The run product glasses generated are broadly granitic and are aluminum- and sodium-rich; however, they are less siliceous than the Evje-Iveland pegmatites. Additionally, the solidus temperature of $900{ }^{\circ} \mathrm{C}$ is significantly higher than the estimated emplacement temperature of $613^{\circ} \pm 70^{\circ} \mathrm{C}$ (Müller et al., 2015) at $500 \mathrm{MPa}$. At the solidus, magnesiohornblende and plagioclase react to produce a melt and a residue of pargasite and lesssodic plagioclase. At temperatures above the solidus, pargasite and the less-sodic plagioclase react to generate larger melt fractions and a residue containing aluminian diopside. The concentration of trace elements, notably scandium and the REEs, in the glasses are significantly lower than the concentrations needed to saturate a melt with minerals such as thortveitite, beryl, columbite-group minerals, etc. REE patterns of the run product glasses are generally flat with minor LREE enrichment and minor positive europium anomalies at low degrees of partial melting. These REE patterns are significantly different from the REE patterns of the Evje-Iveland pegmatites, but are similar to leucosomes in vein-type migmatites produced at low pressures. The differences in major and trace elements, as well as the high solidus temperature of the experimentally derived glasses, as compared to the Evje-Iveland pegmatites, do not support the hypothesis that the rare-element pegmatites were generated by direct anatexis of the host amphibolite. The exception to this may be the leucosomes found at the Iveland Wall, which, in light of this study, have been interpreted to have a similar petrogenesis to the leucosomes in vein-type migmatites (e.g. Sawyer, 1991). Thus, it is suggested that two generations of melts are present in the Evje-Iveland pegmatite field. One generation of melt is related to direct anatexis and formation of barren pegmatites (leucosomes) such as those found at the Iveland Wall and a second generation of melt related to the formation of the rare-element pegmatites.

An alternate hypothesis for the generation of the rare-element pegmatite-forming melt is the partial melting of a scandium-rich ultramafic or mafic complex, differentiation of the partial melt wherein that melt may contain anions that readily complex with scandium, and emplacement of a volatile-rich melt into the host amphibolite. Such complexes are commonly early crystallization and cumulate products during magmatic differentiation. The partial melting of these complexes and magmatic differentiation of those melts may result in the formation of the Flåt metadoritic suite or the Høvringsvatnet granites and the pegmatites may represent the final stages this differentiation. This hypothesis and the connection between the Flåt diorite, Høvringsvatnet granites, and the Evje-Iveland pegmatites warrant further consideration.

The generation of rare-element pegmatite-forming melt by direct anatexis of the host rocks at Evje-Iveland or other localities is not supported by this study. These partial melting experiments demonstrate that melts produced by anatexis of common metamorphic rocks, although broadly granitic in composition, lack the enrichment of volatiles and trace elements commonly seen in LCT and NYF pegmatites. Instead, magmatic differentiation is the preferred model for the formation of rare-element pegmatites.

\section{Uncited reference}

\section{Declaration of Competing Interest}

The authors declare that they have no known competing financial interests or personal relationships that could have appeared to influence the work reported in this paper.

\section{Acknowledgments}

The authors thank Axel Müller for providing the samples necessary for completion of these experiments. Amanda Lindoo and Jing Yang are thanked for technical assistance for performing the piston-cylinder experiments. Emma Bullock is thanked for assistance in performing electron microprobe analyses. A. Jay Kaufman, Richard J. Walker, Sarah C. Penniston-Dorland, and Andrew Houston are also thanked for providing the necessary equipment and assistance in order to process the starting material. Austin M. Gion is currently funded by LabEx VOLTAIRE (LABX-100-01) and EquipEx PLANEX (ANR-11-EQPX-0036) and was also supported by the University of Maryland and the Earth and the Planets Laboratory, Carnegie Institution for Science during his time at those institutions.

\section{Appendix A. Supplementary data}

Supplementary data to this article can be found online at https://doi. org/10.1016/j.lithos.2021.106342.

\section{References}

Adam, J., Green, T.H., Sie, S.H., 1993. Proton microprobe determined partitioning of Rb, $\mathrm{Sr}, \mathrm{Ba}, \mathrm{Y}, \mathrm{Zr}, \mathrm{Nb}$ and $\mathrm{Ta}$ between experimentally produced amphiboles and silicate melts with variable F content. Chem. Geol. 109, 29-49.

Ahven, M., 2012. Rautalammin Kiviniemen granaattipitoinen fayaliittiferrogabro (Petrology and geochronology of the Kiviniemi garnet-bearing fayalite ferrogabbro, Rautalampi) M.Sc. University of Helsinki (62 pp.). 
Ahven, M., 2016. Scandium deposits and potential in Finland. In: 32nd Nordic Geological Winter Meeting, Helsinki, Finland.

Andersen, T., Griffin, W.L., Pearson, N.J., 2002. Crustal evolution in the SW part of the baltic shield: the Hf isotope evidence. J. Petrol. 43, 1725-1747.

Arth, J.G., Hanson, G.N., 1975. Geochemistry and origin of the early Precambrian crust of northeastern Minnesota. Geochim. Cosmochim. Acta 39, 325-362.

Beard, J.S., Lofgren, G.E., 1989. Effect of water on the composition of partial melts of greenstone and amphibolite. Science 244, 195.

Beard, J.S., Lofgren, G.E., 1991. Dehydration melting and water-saturated melting of basaltic and andesitic greenstones and amphibolites at 1, 3, and $6.9 \mathrm{~kb}$. J. Petrol. 32, 365-401.

Beard, C.D., van Hinsberg, V.J., Stix, J., Wilke, M., 2020. The effect of fluorine on clinopyroxene/melt trace-element partitioning. Contrib. Mineral. Petrol. 175, 44.

Bingen, B., van Breemen, O., 1998. U-Pb monazite ages in amphibolite- to granulite-facies orthogneiss reflect hydrous mineral breakdown reactions: Sveconorwegian Province of SW Norway. Contrib. Mineral. Petrol. 132, 336-353.

Bjørlykke, H., 1935. The Mineral Paragenesis and Classification of the Granite Pegmatites of Iveland, Setesdal, Southern Norway.

Bjørlykke, H., 1937. The granite pegmatites of southern Norway. Am. Mineral. 22, 241-255.

Boyd, F.R., England, J.L., 1960. Apparatus for phase-equilibrium measurements at pressures up to 50 kilobars and temperatures up to $1750^{\circ} \mathrm{C}$. J. Geophys. Res. 65, 741-748.

Černý, P., 1991a. Rare-element granitic pegmatites. Part I: anatomy and internal evolution of pegmatitic deposits. Geosci. Canada 18.

Černý, P., 1991b. Rare-element granitic pegmatites. Part II: regional to global environments and petrogenesis. Geosci. Canada 18.

Černý, P., Ercit, T.S., 2005. The classification of granitic pegmatites revisited. Can. Mineral. 43, 2005-2026.

Cerny, P., Meintzer, R.E., Anderson, A.J., 1985. Extreme fractionation in rare-element granitic pegmatites; selected examples of data and mechanisms. Can. Mineral. 23, $381-421$.

Černý, P., Blevin, P.L., Cuney, M., London, D., 2005. Granite-related ore deposits. In: Hedenquist, J.W., Thompson, J.F.H., Goldfarb, R.J., Richards, J.P. (Eds.), One Hundredth Anniversary Volume. Society of Economic Geologists, pp. 337-370.

Chassé, M., Griffin, W.L., O'Reilly, S.Y., Calas, G., 2017. Scandium speciation in a world-class lateritic deposit. Geochem. Perspect. Lett. 3, 105-114.

Chassé, M., Griffin, W.L., Alard, O., O’Reilly, S.Y., Calas, G., 2018. Insights into the mantle geochemistry of scandium from a meta-analysis of garnet data. Lithos 310-311, 409-421.

Clark, G.S., Černý, P., 1987. Radiogenic 87Sr, its mobility, and the interpretation of Rb-Sr fractionation trends in rare-element granitic pegmatites. Geochim. Cosmochim. Acta 51, 1011-1018.

Droop, G.T.R., 1987. A general equation for estimating $\mathrm{Fe} 3+$ concentrations in ferromagnesian silicates and oxides from microprobe analyses, using stoichiometric criteria. Mineral. Mag. 51, 431-435.

Drüppel, K., Elsäßer, L., Brandt, S., Gerdes, A., 2012. Sveconorwegian mid-crustal ultrahigh-temperature metamorphism in Rogaland, Norway: U-Pb LA-ICP-MS geochronology and pseudosections of sapphirine granulites and associated paragneisses. J. Petrol. 54, 305-350.

Dymek, R.F., 1983. Titanium, aluminium and interlayer cation substitutions in biotite from high-grade gneisses, West Greenland. Am. Mineral. 68, 880-899.

Fairfield, P., Lonley, R., Widenbar, L., McEwing, S., Kyle, J., 2018. Sunrise Nickel Cobal Project, New South Wales, Australia NI 43-101 Technical Report, SRK Consulting (Australia) Pty Ltd prepared for Clean TeQ Holdings Limited.

Frost, C.D., Frost, B.R., Beard, J.S., 2016. On silica-rich granitoids and their eruptive equivalents. Am. Mineral. 101, 1268-1284.

Gale, A., Dalton, C.A., Langmuir, C.H., Su, Y., Schilling, J.-G., 2013. The mean composition of ocean ridge basalts. Geochem. Geophys. Geosyst. 14, 489-518.

Gion, A.M., 2020. The Geochemical Behavior of Scandium During Fractional Crystallization and Implications for Ore Formation PhD University of Maryland (349 p).

Goldschmidt, V.M., 1934. Drei Vorträge über Geochemie. Geologiska Föreningen i Stockholm Förhandlingar 56, 385-427.

Gramaccioli, C.M., Campostrini, I., Orlandi, P., 2004. Scandium minerals in the miaroles of granite at Baveno, Italy. Eur. J. Mineral. 16, 951-956.

Guastoni, A., Nestola, F., Ferraris, C., Parodi, G., 2012. Xenotime-(Y) and Sn-rich thortveitite in miarolitic pegmatites from Baveno, Southern Alps, Italy. Mineral. Mag. $76,761$.

Halla, J., 2020. The TTG-amphibolite terrains of Arctic fennoscandia: infinite networks of amphibolite metatexite-diatexite transitions. Front. Earth Sci. 8.

Halliday, A.N., Davidson, J.P., Hildreth, W., Holden, P., 1991. Modelling the petrogenesis of high Rb/Sr silicic magmas. Chem. Geol. 92, 107-114.

Hawthorne, F.C., Oberti, R., Harlow, G.E., Maresch, W.V., Martin, R.F., Schumacher, J.C., Welch, M.D., 2012. Nomenclature of the amphibole supergroup. Am. Mineral. 97, 2031-2048.

Holloway, J.R., Burnham, C.W., 1972. Melting relations of basalt with equilibrium water pressure less than total pressure. J. Petrol. 13, 1-29.

Iveson, A.A., Rowe, M.C., Webster, J.D., Neill, O.K., 2018. Amphibole-, clinopyroxeneand plagioclase-melt partitioning of trace and economic metals in halogen-bearing rhyodacitic melts. J. Petrol. 59, 1579-1604.

Jackson, S., 2008. LAMTRACE data reduction software for LA-ICP-MS. Laser ablation-ICP-mass spectrometry in the earth sciences: current practices and outstanding issues. In: Sylvester, P. (Ed.), Mineralogical Association of Canada (MAC) Short Course Series, 40. pp. 305-307.
Jahns, R.H., 1982. Internal evolution of pegmatite bodes. In: Černý, P. (Ed.), Short Course in Granitic Pegmatites in Science and Industry. Mineralogical Association of Canada, Winnipeg, pp. 293-327.

Jansen, J.B.H., Blok, R.J.P., Bos, A., Scheelings, M., 1985. Geothermometry and geobarometry in Rogaland and preliminary results from the Bamble Area, S Norway. In: Tobi, A.C., Touret, J.L.R. (Eds.), The Deep Proterozoic Crust in the North Atlantic Provinces. Springer Netherlands, Dordrecht, pp. 499-516.

Johan, Z., Ohnenstetter, M., Slansky, E., Barron, L.M., Suppel, D., 1989. Platinum mineralization in the Alaskan-type intrusive complexes near Fifield, New South Wales, Australia part 1. Platinum-group minerals in clinopyroxenites of the Kelvin Grove prospect, owendale intrusion. Mineral. Petrol. 40, 289-309.

Johannes, W., 1978. Melting of plagioclase in the system $\mathrm{Ab}-\mathrm{An}-\mathrm{H}_{2} \mathrm{O}$ and Qz-Ab-An- $\mathrm{H}_{2} \mathrm{O}$ at $\mathrm{P}_{\mathrm{H} 2 \mathrm{O}}=5$ kbars, an equilibrium problem. Contrib. Mineral. Petrol. 66, 295-303.

Jolliff, B.L., Papike, J.J., Shearer, C.K., 1992. Petrogenetic relationships between pegmatite and granite based on geochemistry of muscovite in pegmatite wall zones, Black Hills, South Dakota, USA. Geochim. Cosmochim. Acta 56, 1915-1939.

Kempe, U., Wolf, D., 2006. Anomalously high Sc contents in ore minerals from Sn-W deposits: possible economic significance and genetic implications. Ore Geol. Rev. 28, $103-122$.

Konzett, J., Schneider, T., Nedyalkova, L., Hauzenberger, C., Melcher, F., Gerdes, A., Whitehouse, M., 2018. Anatectic granitic pegmatites from the Eastern Alps: a case of variable rare-metal enrichment during high-grade regional metamorphism - I: mineral assemblages, geochemical characteristics, and emplacement ages. Can. Mineral. 56, 555-602.

Larsen, R.B., Polve, M., Juve, G., 2000. Granite pegmatite quartz from Evje-Iveland: trace element chemistry and implications for the formation of high-purity quartz. Norges Geol. Undersokelse 436, 57-66.

Ling, X.-X., Huyskens, M.H., Li, Q.-L., Yin, Q.-Z., Werner, R., Liu, Y., Tang, G.-Q., Yang, Y.-N., Li, X.-H., 2017. Monazite RW-1: a homogenous natural reference material for SIMS U-Pb and Th-Pb isotopic analysis. Mineral. Petrol. 111, 163-172.

London, D., 1992. The application of experimental petrology to the genesis and crystallization of granitic pegmatites. Can. Mineral. 30, 499-540.

London, D., 2005. Granitic pegmatites: an assessment of current concepts and directions for the future. Lithos 80, 281-303.

London, D., 2008. Pegmatites. Mineralogical Association of Canada.

London, D., 2018. Ore-forming processes within granitic pegmatites. Ore Geol. Rev. 101, 349-383.

Mahood, G., Hildreth, W., 1983. Large partition coefficients for trace elements in high-silica rhyolites. Geochim. Cosmochim. Acta 47, 11-30.

Möller, A., O'Brien, P.J., Kennedy, A., Kröner, A., 2002. Polyphase zircon in ultrahigh-temperature granulites (Rogaland, SW Norway): constraints for $\mathrm{Pb}$ diffusion in zircon. J. Metamorph. Geol. 20, 727-740.

Möller, A., O’Brien, P.J., Kennedy, A., Kröner, A., 2003. Linking growth episodes of zircon and metamorphic textures to zircon chemistry: an example from the ultrahigh-temperature granulites of Rogaland (SW Norway). Geol. Soc. Lond., Spec. Publ. 220, 65.

Müller, A., Flem, B., Snook, B., Bingen, B., Ihlen, P.M., Larsen, R.B., Williamson, B.J., 2015. The chemistry of quartz in granitic pegmatites of Southern Norway: petrogenetic and economic implications. Econ. Geol. 110, 1737-1757.

Müller, A., Husdal, T., Sunde, Ø., Friis, H., Andersen, T., Johansen, T.S., Werner, R., Thoresen, Ø., Olerud, S., 2017a. Norwegian Pegmatites I: Tysfjord-Hamarøy, Evje-Iveland, Langesundsfjord. Geological Society of Norway, Trondheim, Norway.

Müller, A., Romer, R.L., Pedersen, R.-B., 2017b. The Sveconorwegian pegmatite province - thousands of pegmatites without parental granites. Can. Mineral. 55, 283-315.

Müller, A., Spratt, J., Thomas, R., Williamson, B.J., Seltmann, R., 2018. Alkali-F-rich albite zones in evolved NYF pegmatites: the product of melt-melt immiscibility. Can. Mineral. 56, 657-687.

Nandedkar, R.H., Hürlimann, N., Ulmer, P., Müntener, O., 2016. Amphibole-melt trace element partitioning of fractionating calc-alkaline magmas in the lower crust: an experimental study. Contrib. Mineral. Petrol. 171, 71.

Nash, W.P., Crecraft, H.R., 1985. Partition coefficients for trace elements in silicic magmas. Geochim. Cosmochim. Acta 49, 2309-2322.

Neumann, H., 1961. The scandium content of some Norwegian minerals and the formation of thortveitite, a reconnaissance survey. Nor. Geol. Tidsskr. 41, 197-210.

Pedersen, S., 1975. Intrusive rocks of the northern Iveland-Evje area, Aust-Agder. Nor. Geol. Unders. 322, 1-11.

Pedersen, M., 1993. A Geological Study of the Flåt Complex, Aust-Agder, Norway M.Sc. Thesis (in Danish) Copenhagen University (128 p).

Pedersen, S., Andersen, T., Konnerup-Madsen, J., Griffin, W.L., 2009. Recurrent mesoproterozoic continental magmatism in South-Central Norway. Int. J. Earth Sci. 98, 1151-1171.

Petford, N., Gallagher, K., 2001. Partial melting of mafic (amphibolitic) lower crust by periodic influx of basaltic magma. Earth Planet. Sci. Lett. 193, 483-499.

Pezzotta, F., Diella, V., Guastoni, A., 2005. Scandium silicates from the Baveno and Cuasso al Monte NYF-granites, Southern Alps (Italy): mineralogy and genetic inferences. Am. Mineral. 90, 1442-1452.

Rangott, M., Hutchin, S., Basile, D., Ricketts, N., Duckworth, G., Rowles, T.D., 2016. Feasibility Study - Nyngan Scandium Project NI 43-101 Technical Report.

Rapp, R.P., 1995. Amphibole-out phase boundary in partially melted metabasalt, its control over liquid fraction and composition, and source permeability. J. Geophys. Res. 100, 15601-15610.

Rapp, R.P., Watson, E.B., 1995. Dehydration melting of metabasalt at 8-32 kbar: implications for continental growth and crust-mantle recycling. J. Petrol. 36, 891-931. 
Rapp, R.P., Watson, E.B., Miller, C.F., 1991. Partial melting of amphibolite/eclogite and the origin of Archean trondhjemites and tonalites. Precambrian Res. 51, 1-25.

Romer, R.L., Smeds, S.-A., 1996. U-Pb columbite ages of pegmatites from Sveconorwegian terranes in southwestern Sweden. Precambrian Res. 76, 15-30.

Rosing-Schow, N., Müller, A., Friis, H., 2018. A comparison of the mica geochemistry of the pegmatite fields in Southern Norway. Can. Mineral. 56, 463-488.

Rudnick, R.L., Gao, S., 2003. Composition of the continental crust. In: Holland, H.D., Turekian, K.K. (Eds.), Treatise on Geochemistry. Pergamon, Oxford, pp. 1-64.

Rushmer, T., 1991. Partial melting of two amphibolites: contrasting experimental results under fluid-absent conditions. Contrib. Mineral. Petrol. 107, 41-59.

Sawyer, E.W., 1991. Disequilibrium melting and the rate of melt-residuum separation during migmatization of mafic rocks from the Grenville Front, Quebec. J. Petrol. 32, 701-738.

Schaller, T., Dingwell, D.B., Keppler, H., Knöller, W., Merwin, L., Sebald, A., 1992. Fluorine in silicate glasses: a multinuclear nuclear magnetic resonance study. Geochim. Cosmochim. Acta 56, 701-707.

Schärer, U., Wilmart, E., Duchesne, J.-C., 1996. The short duration and anorogenic character of anorthosite magmatism: UPb dating of the Rogaland complex, Norway. Earth Planet. Sci. Lett. 139, 335-350.

Scherer, E., Münker, C., Mezger, K., 2001. Calibration of the Lutetium-Hafnium clock. Science 293, 683.

Schetelig, J., 1911. Über Thortveitit, ein neues Mineral. Centralblatt für Mineralogie, Geologie und Paläontologie, pp. 721-726.

Seydoux-Guillaume, A.-M., Montel, J.-M., Bingen, B., Bosse, V., de Parseval, P., Paquette, J.-L., Janots, E., Wirth, R., 2012. Low-temperature alteration of monazite: fluid mediated coupled dissolution-precipitation, irradiation damage, and disturbance of the U-Pb and Th-Pb chronometers. Chem. Geol. 330-331, 140-158.

Simmons, W., Falster, A., Webber, K., Roda-Robles, E., Boudreaux, A.P., Grassi, L.R., Freeman, G., 2016. Bulk composition of Mt. mica pegmatite, maine, USA: implications for the origin of an LCT type pegmatite by anatexis. Can. Mineral. 54, 1053-1070.

Snook, B., 2014. Towards Exploration Tools for High Purity Quartz: An Example From the South Norwegian Evje-Iveland Pegmatite Belt PhD University of Exeter (284 pp.).

Steffenssen, G., Müller, A., Rosing-Schow, N., Friis, H., 2019. The distribution and enrichment of scandium in garnets from the TØrdal pegmatites, south Norway, and its economic implications. Can. Mineral. 57, 799-801.

Stilling, A., Ćerný, P., Vanstone, P.J., 2006. The tanco pegmatite at Bernic Lake, Manitoba. Xvi. Zonal and bulk compositions and their petrogenetic significance. Can. Mineral. 44, 599-623.

Taylor, B.E., Friedrichsen, H., 1983a. Light stable isotope systematics of granitic pegmatites from North America and Norway. Chem. Geol. 41, 127-167.
Taylor, B.E., Friedrichsen, H., 1983b. Oxygen and hydrogen isotope disequilibria in the Landsverk I pegmatite, Evje, southern Norway: evidence for anomalous hydrothermal fluids. Nor. Geol. Tidsskr. 63, 199-209.

Tuthill, R.L., 1968. The Hydrothermal Behavior of Basalts in Their Melting Range at 5 Kilobars MSc Pennsylvania State University.

Van Westrenen, W., Blundy, J., Wood, B., 1999. Crystal-chemical controls on trace element partitioning between garnet and anhydrous silicate melt. Am. Mineral. 838.

Vander Auwera, J., Bolle, O., Bingen, B., Liégeois, J.P., Bogaerts, M., Duchesne, J.C., De Waele, B., Longhi, J., 2011. Sveconorwegian massif-type anorthosites and related granitoids result from post-collisional melting of a continental arc root. Earth Sci. Rev. 107, 375-397.

Walker, R.J., Hanson, G.N., Papike, J.J., 1989. Trace element constraints on pegmatite genesis: Tin Mountain pegmatite, Black Hills, South Dakota. Contrib. Mineral. Petrol. 101, 290-300.

Webber, K.L., Simmons, W.B., Falster, A.U., Hanson, S.L., 2019. Anatectic pegmatites of the Oxford County pegmatite field, Maine, USA. Can. Mineral. 57, 811-815.

Westphal, M., Schumacher, J.C., Boschert, S., 2003. High-temperature metamorphism and the role of magmatic heat sources at the Rogaland Anorthosite Complex in Southwestern Norway. J. Petrol. 44, 1145-1162.

Williams-Jones, A.E., Vasyukova, O.V., 2018. The economic geology of scandium, the runt of the rare earth element litter. Econ. Geol. 113, 973-988.

Winther, K.T., Newton, R.C., 1991. Experimental melting of hydrous low-K tholeiite: evidence onthe origin of Archaean cratons. Bull. Geol. Soc. Den. 39, 213-228.

Wolf, M.B., Wyllie, P.J., 1991. Dehydration-melting of solid amphibolite at $10 \mathrm{kbar}$ : Textural development, liquid interconnectivity and applications to the segregation of magmas. Mineral. Petrol. 44, 151-179.

Wolf, M.B., Wyllie, P.J., 1994. Dehydration-melting of amphibolite at 10 kbar: the effects of temperature and time. Contrib. Mineral. Petrol. 115, 369-383.

Wolf, M.B., Wyllie, P.J., 1995. Liquid segregation parameters from amphibolite dehydration melting experiments. J. Geophys. Res. 100, 15611-15621.

Wyllie, P.J., Wolf, M.B., 1993. Amphibolite dehydration-melting: sorting out the solidus. Geol. Soc. Lond., Spec. Publ. 76, 405.

Yoder, H.S., Tilley, C.E., 1962. Origin of basalt magmas: an experimental study of natural and synthetic rock systems. J. Petrol. 3, 342-532.

Yoder, H.S., Stewart, D.B., Smith, J.R., 1957. Ternary Feldspars. 56. Carnegie Institution of Washington Yearbook, pp. 206-214. 